\title{
Siphonaptera associated with small mammals (Didelphimorphia, Chiroptera, and Rodentia) from northwestern Argentina
}

\author{
M. Fernanda López-BerRizbeitia ${ }^{1,2,3}$ And M. Mónica Diaz $1,2,3 *$ \\ ${ }^{1}$ Programa de Investigaciones de Biodiversidad Argentina (PIDBA), Programa de Conservación de los Murciélagos de Argentina \\ (PCMA), Facultad de Ciencias Naturales e Instituto Miguel Lillo, Universidad Nacional de Tucumán, Miguel Lillo 205, San Miguel \\ de Tucumán, CP 4000, Argentina. E-mail: mflopezberri@hotmail.com (MFLB), mmonicadiaz@yahoo.com.ar (MMD) \\ ${ }^{2}$ Consejo Nacional de Investigaciones Científicas y Técnicas (CONICET), Tucumán, Argentina. \\ ${ }^{3}$ Fundación Miguel Lillo, Tucumán, Argentina \\ *Corresponding author
}

\begin{abstract}
Northwestern Argentina (NOA) is one of the least studied areas in Argentina with respect to ectoparasites of the order Siphonaptera; previous investigations, until this study, were scarce and specific. The objective of this study was to contribute to the knowledge of the diversity of siphonaptera that parasitize small mammals from the NOA, emphasizing in their systematics and distribution. Specimens of fleas collected in several localities of NOA, and stored in the "Annexes" of the Colección Mamíferos Lillo, Universidad Nacional de Tucuman, Argentina, were studied. Fleas were manually removed from the host pelage, fixed in alcohol $70 \%$ and prepared following conventional techniques for later observation under microscope. For specimen identification, the original descriptions of species and subspecies were reviewed and compared with specimens stored in systematic collections. Nine families, 22 genera, 53 species, and eight subspecies were recorded. A new family, a new genus, and three new species are recorded for the first time in Argentina; five species are new for NOA and nine are new to science. The distribution of 11 species and two subspecies are extended in the NOA, new records are added to different provinces and new flea-hosts associations are reported. The greatest diversity of fleas in the Yungas is the reflection of one of the areas with the highest biodiversity in the Neotropical region, such as the Yungas forests, which also includes mammals, as sigmodontine rodents and bats among them. The similarity analysis among eco-regions showed a major faunistic congruence between the Yungas and the Dry Chaco. The greatest differentiation was given by the High Andes and Puna compared with the other eco-regions, probably because these areas are the least surveyed and with the lowest richness and abundance of small mammal species. From the total of 82 new flea-host associations, 81 belong to sigmodontine rodent hosts and one to a marsupial.
\end{abstract}

El Noroeste Argentino (NOA) representa una de las áreas de Argentina menos estudiada en lo que respecta a ectoparásitos del orden Siphonaptera; las investigaciones, hasta este estudio, eran escasas y puntuales. El objetivo del presente trabajo fue contribuir al conocimiento de la diversidad de sifonápteros que parasitan micromamíferos del NOA, con énfasis en la sistemática y distribución. Se estudiaron ejemplares de sifonápteros procedentes de varias localidades del NOA depositados en los "anexos" de la Colección Mamíferos Lillo, Universidad Nacional de Tucuman, Argentina. Las pulgas fueron recolectadas manualmente del pelaje de los hospedadores, fijadas en alcohol $70 \%$ y preparadas siguiendo las técnicas convencionales para su posterior observación al microscopio óptico. Para la identificación de los ejemplares se revisaron las descripciones originales de especies y subespecies y se compararon los ejemplares con aquellos depositados en colecciones de referencia. Se registraron nueve familias, 22 géneros, 53 especies y ocho subespecies. Una nueva familia, un nuevo género y tres nuevas especies se citan por primera vez para Argentina, cinco especies son nuevas para el noroeste y nueve son nuevas especies para la ciencia. Se extiende la distribución de 11 especies y dos subespecies en el NOA, se suman nuevos registros para las diferentes provincias y se reportan nuevas asociaciones sifonáptero-hospedador. La mayor diversidad de pulgas en la eco-región de Yungas es un reflejo de una de las áreas de más alta biodiversidad en la región Neotropical como son las selvas de Yungas, incluyendo a los mamíferos y, entre ellos, a los roedores sigmodontinos y los murciélagos. El análisis del grado de afinidad entre eco-regiones mostró una mayor congruencia faunística entre las Yungas y el Chaco Seco. La mayor diferenciación estuvo dada por los Altos Andes y la Puna con respecto al resto, probablemente porque son dos de las áreas menos muestreadas y con menor riqueza y abundancia de especies de micromamíferos. Del total de 82 nuevas asociaciones sifonáptero-hospedador, 81 poseen como hospedadores a los roedores sigmodontinos, y una asociación está constituida por un marsupial.

Key words: Argentina; eco-regions; fleas; host; new records; taxonomic.

(C) 2019 Asociación Mexicana de Mastozoología, www.mastozoologiamexicana.org

\section{Introduction}

Fleas are ectoparasites of higher vertebrates, mainly abundant and diverse in mammals, hosting $94 \%$ of the known flea species. In Argentina, the fleas reported mostly represents new distributional records, some increasing the number of species for the studied areas or regions, also extending their geographical range as well as reporting new flea-host associations (Lareschi et al. 2003, 2010; Autino et al. 2005; Sanchez et al. 2009; Claps and Autino 2012; López-Berrizbeitia 2013a, b; Sanchez and Lareschi
2013). Some studies describe new species for science, mainly from central and southern Argentina (see Manhert 1976; Beaucournu and Torres-Mura 1987; Beaucournu and Gallardo 1988, 2005; Beaucournu and Alcover 1990; Hastriter 2001; Beaucournu et al. 2004; Hastriter and Sage 2009, 2011; Sanchez and Lareschi 2014b; Ezquiaga et al. 2015; Sanchez et al. 2015), and more recently from the northwest (Beaucournu and Castro 2002, 2003; LópezBerrizbeitia et al. 2015a, b, 2016; López-Berrizbeitia et al. 2018, 2019). 
Until this study, Northwestern Argentina (NOA) represented one of the areas in the country where the studies of ectoparasites of the order Siphonaptera were very scarce and punctual. Even though, in the last years, the small mammals surveys have increased in the region (Díaz et al. 1999, 2000; Díaz and Barquez 1999, 2007; Flores et al. 2000; Barquez et al. 2009; Ferro and Barquez 2009; Jayat and Ortiz 2010; Sandoval et al. 2010; Barquez et al. 2011; Jayat et al. 2011; Gamboa Alurralde et al. 2016), in Catamarca, La Rioja, and Santiago del Estero provinces, the small mammals have been scarcely surveyed. The data presented here are the results of extensive field surveys, laboratory work, and collection revision coming from a doctoral thesis (LópezBerrizbeitia et al. 2018).

In the natural communities, small mammals are the most numerous animals (Ferro 2012), and in the NOA, they are represented by marsupials, bats, and rodents. Rodents are the most diverse taxon and are represented by several families, being the family Cricetidae, subfamily Sigmodontinae, the most numerous, besides being distributed throughout South America (Barquez et al. 2006; Patton et al. 2015). The sigmodontine rodents are found in every habitat in the NOA, from tropical forests to Andean High deserts (Ferro 2012). Marsupials belong to the order Didelphimorphia, family Didelphidae, this taxon is represented by four genera and 10 species (Barquez et al. 2006; Voss and Jansa 2009). Finally, the order Chiroptera is represented by four families and 44 species, being Vespertilionidae the most specious family with 17 species, followed by Molossidae (13), Phyllostomidae (12), and Noctilionidae with two species (Barquez and Díaz 2009; Díaz et al. 2016; Urquizo et al. 2017; Barquez et al. 2017).

In Argentina, most records of fleas come from rodents, perhaps due to the great diversity and abundance of the group, and to a lesser extent come from marsupials and bats (Lareschi et al. 2016). On the other hand, studies are mainly restricted to the central and southern parts of Argentina, where a replacement of the hosts species and a decrease of diversity can be observed (Barquez et al. 2006; Barquez and Díaz 2009; Udrizar Sauthier and Pardiñas 2014); also in the northwest, marsupial and bat richness is notably greater than in southern Argentina (Barquez et al. 2006; Gardner 2008).

For a long time, the identification of host species was considered as not relevant for parasitological studies; in fact, in the literature there are mentioned several flea records collected from unknown hosts, or with their identifications not reaching species or even genus level (Hopkins and Rothschild 1953, 1956, 1966; Smit 1987; Del Ponte 1977; Autino and Lareschi 1998). Sometimes taxonomic identification in poorly known groups can be troublesome, but it is of essential importance since it allows analyses of several aspects of host parasite relationships such as co-evolutionary processes, and even to identify species that can act as disease reservoirs. Based on this, it is important to highlight the importance of developing interdisciplinary studies between parasitologists and mammalogists tending to ensure cor- rect taxonomic identification of both, parasites and hosts, mitigate the gaps in the knowledge of both groups (Fernandez 2019) and to avoid erroneous conclusions in research. In this context, the principal objective of this research was to study the faunistic composition of fleas (Siphonaptera) parasitizing small mammals (Didelphimorphia, Chiroptera, and Rodentia) in Northwestern Argentina.

\section{Materials and methods}

Study area. Northwestern Argentina is integrated by the provinces of Catamarca, Jujuy, La Rioja, Salta, Santiago del Estero, and Tucuman (Carlevari 1994; Bolsi et al. 1997a, $\underline{\mathrm{b}}$; Figure 1). The region is complex because it harbors a great variety of landscapes (Santillán de Andrés and Ricci 1998), which is reflected in its diversity of flora and fauna (Burkart et al. 1999). Biogeographically, NOA is part of the Neotropical Region, one of the greatest phytogeographical regions on earth, and occupies most part of the Argentine territory, sharing the Amazonian, Chacoan, and Andean-Patagonian Dominions (Cabrera 1976). According to Burkart et al. (1999), the eco-regions recorded in the NOA are: Yungas (Amazonian Dominion), High Andes and Puna (AndeanPatagonian Dominion), Dry Chaco, Monte Desert of Mountains and Isolated Valleys, and a small portion of Humid Chaco (Chaco Dominion; Figure 1).

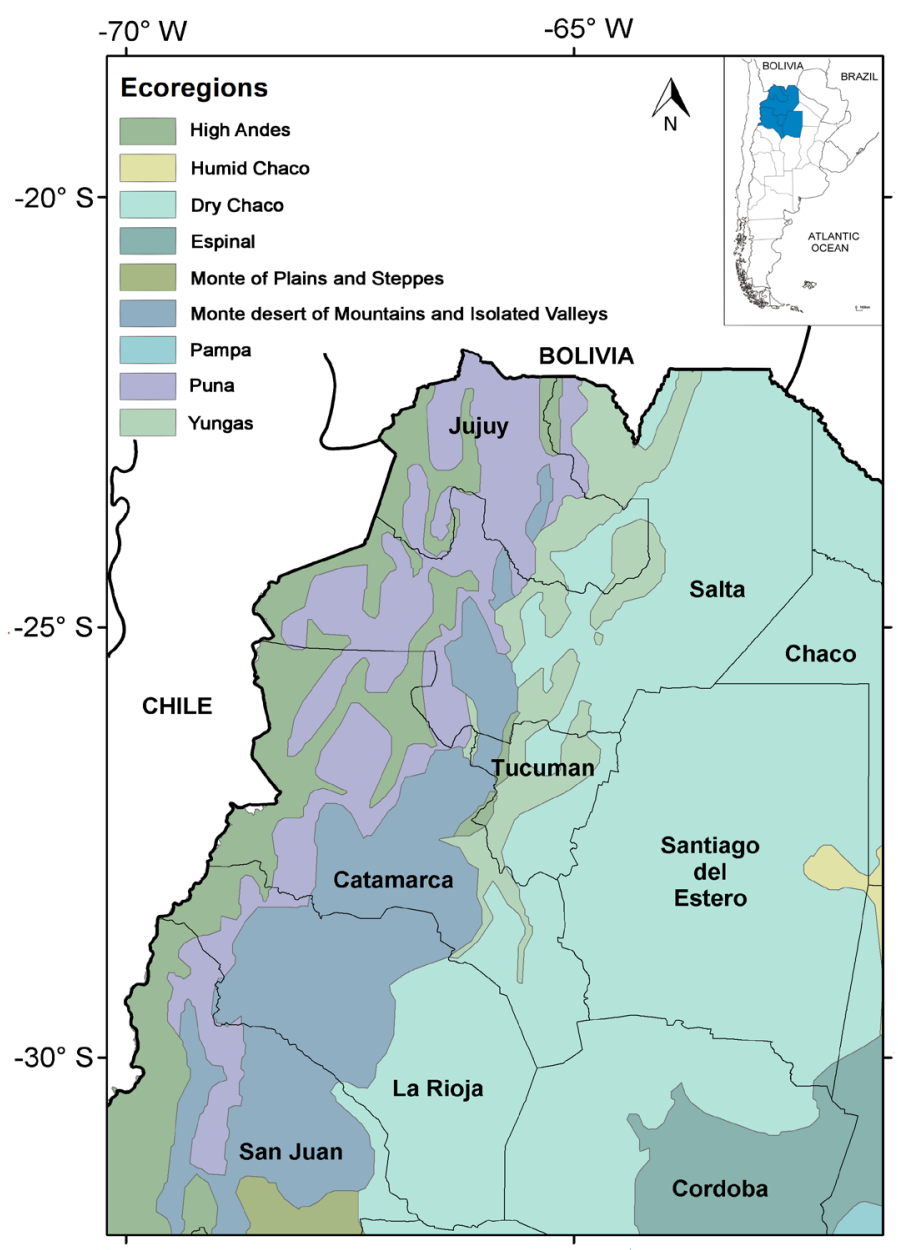

Figure 1. Geographic location of northwestern Argentina, limits, provinces and ecoregions. 
Collection and preparation of specimens. In the "annexes" of the Colección Mamíferos Lillo, Universidad Nacional de Tucuman, an important number of flea specimens (Insecta: Siphonaptera) were stored from several localities of NOA. These specimens are the results of surveys carried out over several years; all specimens were reviewed and analyzed during this study. Also, surveys to all provinces of NOA were carried out, prioritizing areas with absence of data (Appendix I).

Collection of small mammals. Small terrestrial mammals were captured with Sherman live traps baited with oats, set on two or three transects of 60 traps each, and placed in different habitats at each sampling locality. For small fossorial mammals we placed traps designed for the live capture of subterranean rodents, modified from the model by Baker and Williams (1972). The traps were placed at fresh mounds, the tunnel hole was opened and the extreme of the pipe was inserted into the burrow with the device activated. Bats were captured using four or six $12 \mathrm{~m}$ mist nets set on different habitats. Specimens representing unusual records, or with uncertain identification, or with presence of fleas detected for the first time, were collected as voucher specimens. Permits issued by the provincial authorities for Administration of Natural Resources of each province of the NOA authorized the collection of these specimens. Most of the specimens were deposited at the Colección Mamíferos Lillo (CML), Facultad de Ciencias Naturales e Instituto Miguel Lillo, Universidad Nacional de Tucuman, Tucuman, and a small part was deposited at the Sam Noble Oklahoma Museum of Natural History (SNOMNH), University of Oklahoma, Norman, Oklahoma. Some specimens are still being catalogued and acronyms used in the text are: CLH (personal catalogue of Carlos Luis Hoyos), EMG (personal catalogue of Enrique M. Gonzalez), LIF (personal catalogue of Luis Ignacio Ferro), MIC (personal catalogue of María Inés Carma), and MMD (personal catalogue of María Mónica Díaz).

For taxonomic identification of small mammals we followed Díaz et al. (1997), Braun and Díaz (1999), and Barquez and Díaz (2009). The basic checklist used was based on Barquez et al. (2006), Gardner (2008), and Patton et al. (2015).

Processing of Siphonaptera. The specimens were removed manually from the host pelage with toothbrushes and forceps, preserved in a solution of $70 \%$ ethyl alcohol, and prepared following conventional techniques for taxonomic identification (see Hastriter and Whiting 2003).

Systematic analysis of Siphonaptera. Nomenclature follows Whiting et al. (2008), and keys and descriptions of Hopkins and Rothschild (1953, 1956, 1962, 1966), Johnson (1957), Smit (1987), Hastriter and Mendez (2000), and Linardi and Guimarães (2000) were used. With the purpose of species identification, specimens were compared with original descriptions of species and subspecies and with specimens stored in the following collections: Annexes of the Colección Mamíferos Lillo (CMLA; Universidad Nacio- nal de Tucuman, Argentina), British Museum (Natural History; BMHN; London, United Kingdom), Muséum d'Histoire Naturelle (MHN; Paris, France), and Monte L. Bean Life Science Museum, Brigham Young University (BYU; Provo, Utah, United States, including the flea collection of Michael W. Hastriter and Vernon J. Tipton).

Localities and maps. A total of 154 localities were recorded. Geographic coordinates for localities sampled by us were obtained with Geographic Positioning System (GPS) and those from the literature were determined using the Google Earth Pro Versión 2016. Some localities were not mapped, because the original localities were imprecise or with absence of data. It is also important to mention that corrected coordinates of some localities, erroneously reported in the literature, were obtained. The map of NOA including provinces and ecoregions (Figures 1) was designed with the ArcGis 10.1 program (ESRI 2011).

All localities were ordered numerically and alphabetically, with the provincial department indicated between parentheses (see Appendix I).

Species accounts. In this section we report all species known from the NOA, including those published on literature with confirmed identity. Accounts include scientific name, author, general distribution, distribution in Argentina, and specimens examined (total numbers between parentheses). In specimens examined we included: specific locality, number of specimens by sex and collection number (when known); host species and collection number (when known). Some included specimens are distributed out the study area (Appendix II), but they were used for description purposes. In additional specimens only the locality and hosts were included. Under "Comments" we summarize available information about natural history and taxonomy of each species.

Similarity analysis. To evaluate the affinity of species among ecoregions in the NOA we carried out a similarity analysis. The similarity was estimated through the simple presence or absence of species in different ecoregions to analyze the degree of interrelationships among them.

We applied Jaccard's Coefficient ( $J$ ), one of the most used qualitative estimators (Jost et al. 2011), which allows the use of qualitative data such as presence-absence of the organisms (Moreno 2001); its value varies from 0 (no shared species between two sites) and 1 (the two sites have the same composition of species) and was calculated with the formula:

Where $a$ is the number of species present in site $A ; b$ is the number of species present in site $B$; and $c$ is the number of species present in both sites, $A$ and $B$.

The index was calculated with the PAST 1.18 program (Hammer et al. 2001) using the unweighted pair-group arithmetic averaging cluster algorithm (UPGMA) based on similarity values, and expressed in a dendrogram through an analysis of Clusters using the same program PAST 1.18. 


\section{Results}

Species Accounts. In the present study, nine families of the order Siphonaptera parasitizing small mammals of the orders Didelphimorphia, Chiroptera, and Rodentia in the NOA were recorded (Table 1). The number of genera, species, and subspecies for each families are detailed as follows: Tungidae, one genus and six species; Pygiopsyllidae, one genus and one species; Stephanocircidae, five genus and seven species; Rhopalopsyllidae, five genus, 27 species, and two subspecies; Ctenophthalmidae, three genus, five species, and three subspecies; Pulicidae, two genus and two species; Leptopsyllidae, one genus and one species; Ischnopsyllidae, three genus, four species, and two subspecies; and Ceratophyllidae, one genus and one species.

\section{Family Tungidae \\ Subfamily Tunginae \\ Tribe Hectopsyllini}

Genus Hectopsylla Frauenfeld 1860

Hectopsylla (Hectopsylla) gracilis Mahnert 1982

General distribution. Endemic to Argentina (Lareschi et al. 2016).

Distribution in Argentina. This species was previously known from the provinces of Chubut, Jujuy, Mendoza, Neuquén, Río Negro (Lareschi et al. 2016), Salta (López-Berrizbeitia 2013a) and La Rioja (López-Berrizbeitia et al. 2013b, 2017); in this study it is added to Catamarca and Tucuman provinces.

Specimens Examined (24). Catamarca: Las Juntas, 1 female (no number), ex Akodon spegazzinii Thomas 1897 (MIC 86). Chubut: Puerto Madryn, 1 paratype female (BMNH no number), ex Eligmodontia typus F. Cuvier 1837 (unknown number). Jujuy: Arroyo La Horqueta, a $6 \mathrm{~km}$ al SE de las Lagunas de Yala, 1 female (no number), ex Akodon caenosus Thomas 1918 (CML 4617); Sobre ruta 40, $29 \mathrm{~km}$ al N del empalme con ruta 52, 1 female (no number), ex Akodon albiventer Thomas 1897 (CML 4574), 3 females (no numbers), ex Eligmodontia hirtipes (Thomas 1902; CML 8315, 9443, 9445), 4 females (no numbers), ex Eligmodontia puerulus (Philippi 1896; CML 8316, 9466, 9468). La Rioja: $2 \mathrm{~km}$ al S pasando río de La Punta sobre ruta provincial 7, 1 male (CMLA 600), ex Graomys chacoensis (J.A. Allen 1901; CML 12948); a $800 \mathrm{~m}$ al E de la entrada de Anillaco sobre ruta Nacional 75, 4 females (CMLA 594, 595, 596, 597), ex Andalgalomys olrogi Williams and Mares, 1978 (CML 9747), 2 females (CMLA 598, 599), ex E. typus (CML 9751), 1 female (CMLA 593), ex G. chacoensis (CML 9748); Anillaco, atrás del cementerio, 2 females (CMLA 601, 602), ex Eligmodontia moreni (Thomas 1896; CML 12943). Salta:Vega Cortadera, 1 female (no number), exE. puerulus (SNOMNH 34757). Tucuman: La Olorosa, 1 female (no number), ex Abrothrix andina (Philippi 1858; released); Peña Colorada, 2 females (no number), ex $A$. andina (released).

Additional Records. Jujuy: Salar Cauchari, $31 \mathrm{~km}$ al N de Cauchari, sobre ruta provincial № 70, Susques, ex E. puerulus (Lareschi et al. 2010).
Remarks. This species is endemic to Argentina (Lareschi et al. 2016). Recently, three new associations were recorded with the following hosts: A. olrogi, G. chacoensis (López-Berrizbeitia 2013a) and E. moreni (López-Berrizbeitia et al. 2017). Others hosts are: Abrothrix olivacea (Waterhouse 1837), Akodon iniscatus Thomas 1919; Abrothrix longipilis (Waterhouse 1837; originally cited as A. hirta); Reithrodon auritus (G. Fischer 1814); Eligmodontia morgani J.A. Allen 1901, and G. griseoflavus (Waterhouse 1837; see Sanchez 2012).

Hectopsylla (Hectopsylla) cypha Jordan 1942

General distribution. Argentina and Chile (Beaucournu et al. 2014; Lareschi et al. 2016).

Distribution in Argentina. La Rioja, Mendoza, Río Negro, and Tucuman provinces (Lareschi et al. 2016).

Specimens Examined (2). Mendoza: San Rafael, 1 holotype male (BMNH 1940-217), 1 allotype female (BMNH 1940217), ex Microcavia maenas (Thomas 1898; unknown number; originally identified as Microcavia australis I. Geoffroy and d'Orbigny 1833).

Additional Records. La Rioja: Zapallar, ex Lagostomus sp. (Hastriter and Méndez 2000). Tucuman: not specific locality, unknown host (Beaucournu and Castro 2003).

Remarks. Examined specimens correspond to deposited specimens in the Natural History Museum. Originally, the type host species was $M$. australis, but according to geographical distribution in Teta et al. (2017) this species is not distributed in Mendoza Province and it corresponds to $M$. maenas. Regarding the recorded host in the La Rioja Province, it could be Lagostomus maximus (Desmarest 1817), since it is the only extant species of the genus. This species was recorded parasitizing others rodents in the Mendoza Province: Graomys griseoflavus, Octomys mimax Thomas 1920, and Tympanoctomys barrerae (Lawrence 1941; see Lareschi et al. 2016).

\section{Hectopsylla (Hectopsylla) gemina Jordan 1939}

General distribution. Argentina and Chile (Beaucournu et al. 2014; Lareschi et al. 2016).

Distribution in Argentina. Buenos Aires, La Pampa, Mendoza, Río Negro, San Juan, and Santiago del Estero provinces (Lareschi et al. 2016); in this study it is added to Tucuman Province.

Specimens Examined (3). Mendoza: Puesto "La Carpa", 1 male (BMNH 1959-683), ex M. maenas (unknown number; originally identified as M. australis). Rio negro: Fortín Uno, 1 holotype female (BMNH 1940-217), ex M. australis (unknown number). Tucuman: Parque Nacional Campo de Los Alisos, El Kerqueo, 1 female (no number), ex Phyllotis osilae J. A. Allen, 1901 (CML 11676).

Additional Records. Santiago del Estero: not specific locality, ex Microcavia jayat Teta, Ojeda, Lucero, and D'Elía 2017 (originally cited as M. australis; Autino and Lareschi 1998).

Remarks. Others recorded hosts for this species in Argentina are: Akodon sp., G. griseoflavus (Cricetidae), Cavia sp., Galea leucoblephara Burmeister 1861 (originally cited as G. 
musteloides Meyen 1833; Caviidae), Ctenomys sp. (Ctenomyidae), and T. barrerae (Octodontidae; Hastriter and Méndez 2000; Lareschi et al. 2016). Phyllotis osilae represents a new host for this species of flea. According to Hastriter and Mendez (2000) this species shows preference for M. australis; however, in this study, we recorded the species P. osilae, a cricetid rodent of the tribe Phyllotini.

Hectopsylla (Hectopsylla) psittaci Frauenfeld 1860

General distribution. Argentina, Brazil, Chile, United States, and Great Britain (Beaucournu et al. 2014; Lareschi et al. 2016).

Distribution in Argentina. Buenos Aires, La Rioja, and Tucuman provinces (Lareschi et al. 2016).

Specimens Examined. None.

Additional records. Tucuman: not specific locality, ex Eumops perotis (Schinz 1821; originally cited as Promops perotis; Del Ponte and Riesel 1939).

Remarks. This species is primarily a parasite of birds. It is native to the southern cone of South America, but with populations dispersed by migratory birds in Europe and southwestern United States (Hastriter and Méndez 2000). The associtation with E. perotis is accidental (Del Ponte and Riesel 1939).

\section{Hectopsylla (Hectopsylla) stomis Jordan 1925}

General distribution. Endemic to Argentina (Lareschi et al. 2016).

Distribution in Argentina. Buenos Aires, La Pampa, Mendoza, Salta, and Santiago del Estero provinces (Lareschi et al. 2016).

Specimens Examined (1). Buenos Aires: Cañada Mariano, 1 holotype female (BMNH 1923-615), ex bird (unknown number).

Additional Records. Salta: El Quebrachal, ex L. maximus (Hopkins and Rothschild 1953). Santiago del Estero: El Ojito, pica de Santiago del Estero, ex L. maximus (Hopkins and Rothschild 1953).

Remarks. The only examined specimen corresponds to a female deposited in the Natural History Museum, London, England. Like $H_{\text {. }}(H$.$) gracilis, it is an endemic species to$ Argentina. Other recorded hosts are: G. griseoflavus and $M$. maenas in La Pampa and Mendoza provinces, respectively (Lareschi et al. 2016); and although, this species was recorded on L. maximus in Northwestern Argentina, its presence on small mammals is highly probable.

\section{Hectopsylla (Rhychopsyllus) pulex (Haller 1880)}

General distribution. Argentina, Brazil, United States, and Mexico (Lareschi et al. 2016).

Distribution in Argentina. Buenos Aires, Catamarca, La Pampa, Salta, and Tucuman provinces (Lareschi et al. 2016).

Specimens Examined (6). Jujuy: Río Lavayén, aproximadamente $1 \mathrm{~km}$ al $\mathrm{N}$ de Santa Rita, 2 females (no number), ex Tadarida brasiliensis (I. Geoffroy St. Hilaire 1824; CML 7077). Salta: Parque Nacional El Rey, 3 females (no number), ex $T$. brasiliensis (released). Tucuman: Dique Escaba, 1 female (no number), ex T. brasiliensis (released).
Additional Records. Catamarca: El Rodeo, ex T. brasiliensis (Del Ponte 1977). Jujuy: Parque Provincial Potrero de Yala, ex T. brasiliensis (Autino et al. 2016). Salta: $8 \mathrm{~km}$ al $\mathrm{O}$ de Piquirenda Viejo; Río Las Conchas, 2 km al $\mathrm{N}$ y 6 km al O de Metán, ex T. brasiliensis (Autino et al. 2009). Tucuman: San Miguel de Tucuman, ex E. perotis (Schreiter and Shannon 1927).

Remarks. Traditionally $H$. (H.) pulex was included in the genus Rhinchopsyllus, but later Hastriter and Mendez (2000) proposed the synonymy with the genus Hectopsylla. This species parasitizes mainly bats of the family Molossidae but also the family Vespertilionidae (Hastriter and Méndez 2000). In this study, only one female was examined; the males are rare, in fact, previous studies recorded males specimens only associated with the guano of species of the genus Molossus in Colombia and Panama (Tipton and Méndez 1966; Hastriter and Méndez 2000).

Family Pygiopsyllidae

Genus Ctenidiosomus Jordan 1931

Ctenidiosomus austrinus López-Berrizbeitia, Hastriter and Díaz 2015

General distribution. Endemic to Argentina (López-Berrizbeitia et al. 2015a).

Distribution in Argentina. Only known from the type locality in Salta Province (López-Berrizbeitia et al. 2015b).

Specimens Examined (1). Salta: Aproximadamente $15 \mathrm{~km}$ O de Escoipe, sobre ruta Provincial № 33, 1 holotype male (no number) ex P. osilae (CML 8044).

Remarks. The single male holotype was collected from a juvenile male specimen of the sigmodontine rodent, Phyllotis osilae, on May during the dry season. The type locality of Ct. austrinus corresponds to the ecoregion Monte Desert of Mountains and Isolated Valleys and similar to all other species of Ctenidiosomus, the new species was collected at a high elevation $(2680 \mathrm{~m}$.). With this report, the geographical distribution of the genus Ctenidiosomus is extended $\sim 2600 \mathrm{~km}$ further south from its previously known southern limits of El Tambo, Huancayo Province, Junín Department, Peru (Mardon 1981). The presence of this species in Bolivia is highly probable due to its location among Peruvian and Argentine records.

Family Stephanocircidae

Subfamily Craneopsyllinae

Tribe Craneopsyllini

Genus Cleopsylla Rothschild 1914

Cleopsylla barquezi López-Berrizbeitia, Hastriter and Díaz 2016

General distribution. It is only found in NOA (Lopez-Berrizbeitia et al. 2016).

Distribution in Argentina. Catamarca, Salta, and Tucuman provinces (Lopez-Berrizbeitia et al. 2016).

Specimens Examined (20). Catamarca: Cumbre de Humaya, 1 paratype male (CMLA 26), ex Akodon spegazzinii 
Thomas 1897 (MIC 302), 1 paratype female (CMLA 29) ex A. spegazzinii (MIC 312), 2 males (CMLA 27, 30), 2 females (CMLA 28, 31), ex A. spegazzinii (MIC 263, 266, 311); Las Juntas, 1 female (CMLA 22), 2 males (CMLA 23, 24), ex $P$. osilae (MIC 79), 1 female (CMLA 25), ex A. spegazzinii (MIC 85). Salta: aproximadamente $15 \mathrm{~km}$ O Escoipe, sobre ruta Provincial $\mathrm{N}^{\circ}$ 33, 1 paratype male (CMLA 15), 3 paratypes females (CMLA 17, 18, 19), ex A. spegazzinii (CML 9236, SNOMNH 33007), 2 males (CMLA 16, 20), 1 female (CMLA 21), ex A. spegazzinii (CML 9236). Tucuman: 10 km S Tafí del Valle, Santa Cruz, 1 holotype male (CMLA 13), 1 allotype female (CMLA 14), ex $P$. osilae (SNOMNH 30102); Ciénaga Grande, San José de Chasquivil, 1 female (no number), ex A. spegazzinii (CML 7478).

Remarks. The elevation for hosts and specimens of the new species of flea was similar among the localities, fluctuating within a range of 1750-2680 $\mathrm{m}$. The type locality of $C$. barquezi corresponds to highland pastures $(2278 \mathrm{~m})$, the last stratum of the eco-region Yungas Forests. Colombetti et al. (2008) misidentified the new species of $C$. barquezi referring to it as $C$. townsendi. The hosts reported by Colombetti et al. (2008) were not available for our review; therefore, we could not verify their identity.

\section{Genus Craneopsylla Rothschild 1911}

Craneopsylla minerva (Rothschild 1903)

General distribution. Argentina, Brazil, Chile, Ecuador, Paraguay, Peru, Uruguay, and Venezuela (Johnson 1957; Beaucournu et al. 2014; Lareschi et al. 2016).

Distribution in Argentina. Buenos Aires, Catamarca, Cordoba, Chubut, Jujuy, La Pampa, Mendoza, Neuquen, Rio Negro, Salta, Santa Fe, Santiago del Estero, Tierra del Fuego, and Tucuman provinces (Lareschi et al. 2016), and it has been recently included in La Rioja Province (López-Berrizbeitia et al. 2017).

Specimens Examined (203). Argentina. Buenos Aires: Estancia La Daniela, 1 lectotype male (BMNH 1923-615), 1 allotype female (BMNH 1923-615), ex Lutreolina crassicaudata (Desmarest 1804; unknown number; originally identified as Didelphis crassicaudata). Catamarca: $22 \mathrm{~km}$ al SE de Villa de Escaba sobre ruta Prov. No 9, 1 female (no number), ex Akodon glaucinus Thomas 1919 (CML 12346); 3.4 km al S de la unión entre las rutas 18 y 9 provinciales, sobre ruta provincial $N^{\circ} 18,5$ females (no numbers), ex Akodon lutescens J. A. Allen 1901 (SNOMNH 37530); Estancia Narvaez, 5.5 km N La Chacritas en ruta Provincial 1, 3 females (no numbers), ex $A$. spegazinii (CML 7198, 7200); Las Juntas, 1 male (no number), 3 females (no numbers), ex Akodon simulator Thomas 1916 (MIC 104, 130) 6 females (no numbers), 1 male (no number), ex A. spegazzinii (MIC 128), 1 male (no number), 1 female (no number), ex P. osilae (MIC 114). Jujuy: $17 \mathrm{~km}$ al O y $3 \mathrm{~km}$ al S de la Quiaca, sobre ruta provincial No 5, 1 female (no number), ex Phyllotis xanthopygus (Waterhouse 1837; CML 8006); $3 \mathrm{~km}$ del cruce Río Las Capillas y ruta prov. $\mathrm{N}^{\circ}$ 20, 3 females (no numbers), ex Calomys venustus (Thomas 1894; CML 12393); 9 km NO Bárcena, 1 male (no number), 4 females (no numbers), ex Phyllotis caprinus Pearson 1958 (SNOMNH
30082), 3 males (no numbers), 15 females (no numbers), ex $P$. osilae (CML 6501, 8068), 2 males (no numbers), 4 females (no number), ex P. xanthopygus (SNOMNH 34028, 30192); Abra de Santa Laura, límite entre Salta y Jujuy, sobre ruta nacional 9, 1 female (no number), ex Akodon toba Thomas 1921 (CML 4893); Arroyo Los Matos, 7 km N de Las Capillas, 2 males (no numbers), 5 females (no numbers), ex Akodon budini (Thomas 1918; CML 12340, released), 1 male (no number), 5 females (no numbers), ex $A$. spegaziinii (CML 12362), 1 female (no number), ex Oxymycterus paramensis Thomas 1902 (CML 12364); Cerro El Morado, 11 km al NO de San Antonio, sobre Río El Morado, 1 female (no number), ex Euryoryzomys legatus (Thomas 1925; CML 9628); Cuesta del Hurón, 29 km al O de Cieneguillas, sobre ruta provincial 64, 1 male (no number), 7 females (no numbers), ex P. xanthopygus (CML 7969, 7970), 1 female (no number), ex Tapecomys wolffsohni (Thomas 1902; CML 8070); Río Blanco, 9 km SO, San Antonio, 1 female (no number), ex Oligoryzomys brendae Massoia 1998 (SNOMNH 37035); Río Las Capillas, 15 km al N de Las Capillas, por ruta provincial 20, 1 male (no number), 1 female (no number), ex Tapecomys primus Anderson and Yates 2000 (CML 12398); Ruta 83 camino a Valle Grande, 9 km al N de San Francisco, 2 females (no numbers), ex T. primus (CML 7556). La Rioja: $2 \mathrm{~km}$ al E de Malanzán, camping El Descanso, 1 female (CMLA 611), ex G. griseoflavus (CML 13005); $5 \mathrm{~km}$ al S del Cañón del Ocre, 1 female (CMLA 608), ex P. xanthopygus (CML 13020); Cuesta La Cébila, 22 km al NO de Chumbicha, sobre ruta 60, 1 female (no number) ex $A$. glaucinus (CML 3752); Puesto Tres Piedras, 2 females (no numbers), ex Akodon sp. (CML 12900); RP 11, km 81, El Potrerillo, Río El Potrerillo, 1 male (no number), ex G. chacoensis (CML 12960); Ulapes, 1 $\mathrm{km}$ al O de la plaza principal de Ulapes, 2 females (CMLA 609, 610), ex G. chacoensis (CML 12991). Salta: 12.6 km O de Piquirenda Viejo, 1 female (no number), ex E. legatus (CML 9694); A $43.7 \mathrm{~km}$ del cruce de las rutas 50 y 18, camino a Isla de Cañas, sobre ruta 18, 1 female (no number), ex Lutreolina massoia Martínez-Lanfranco, Flores, Jayat, and D’Elía 2014 (CML 7650; originally identified as L. crassicaudata), 1 female (no number), ex Thylamys sponsorius (Thomas 1921; CML 7511); 15 $\mathrm{km}$ al $\mathrm{O}$ de Escoipe, sobre Ruta Provincial N³3, 9 females (no numbers), ex A. spegaziinii (CML 7213); $2 \mathrm{~km}$ al $\mathrm{N}$ y $6 \mathrm{~km}$ al O de Metán, sobre Río Las Conchas, 3 males (no numbers), 4 females (no numbers), ex A. lutescens (CML 12363), 1 female (no number), ex Akodon puer Thomas 1902 (CML 12345), 1 female (no number), ex $A$. simulator (CML 12349), 1 female (no number), ex O. brendae (CML 12374), 1 male (no number), 1 female (no number), ex Oligoryzomys flavescens (Waterhouse 1837; CML 12377); 3 km N Cachi Adentro, 2 males (no numbers), 2 females (no numbers), ex G. griseoflavus (SNOMNH 33335); 3.5 km al O de Metán, 1 male (no number), 2 females (no numbers), ex $A$. simulator (CML 12352), 3 males (no numbers), 4 females (no numbers), ex 0 . brendae (CML 12374, 12375, 12376), 1 male (no number), 1 female (no number), ex O. flavescens (CML 12379); Cuesta Chica, 35 km O del Oculto, 4 km E de San Andrés, 1 female (no number), ex 0. paramensis (CML 11498); El Oculto, ruta provincial $N^{\circ} 18, \mathrm{~km}$ 
25 sobre Río Blanco (camino a San Andrés), 1 female (no number), ex E. legatus (CML 11600); Hipólito Yrigoyen, 1 male (no number), 3 females (no numbers), ex Calomys boliviae (Thomas 1901; CML 49, 52), Akodon tartareus Thomas 1919 (CLH 59); Laguna de Pintascayo, 1.5 km N sobre Río Pescado frente a Quebrada del Café, 1 female (no number), ex A. simulator (LIF 935); Pintascayo, campamento Lima (Propiedad de GMF S.A), 2 females (no numbers), ex Akodon cf. fumeus (MMD 5172), 1 male (no number), 2 females (no numbers), ex T. sponsorius (CML 10109); Río Los Sauces, 12 km NO del Jardín, ruta 6 km 110, 1 female (no number), ex C. venustus (LIF 190). Santiago del Estero: Salinas de Ambargasta, $\sim 8 \mathrm{~km}$ SE Cerro Rico, 2 females (no numbers), ex C. venustus (CML 6763, 6764). Tucuman: 1.9 $\mathrm{km}$ NE Hualinchay sobre ruta provincial 311, 1 male (no number), ex O. brendae (SNOMNH 34359); Arroyo Aguas Chiquitas, Reserva Provincial Aguas Chiquitas, 1 male (no number), 2 females (no numbers), ex $A$. simulator (CML 3807); Ciénaga Grande, San José de Chasquivil, 1 male (no number), 1 female (no number), ex $A$. spegazzinii (CML 7478), 1 female (no number), ex P. osilae (CML 8461); Dique San Ignacio, 1 female (no number), ex $A$. simulator (CML 7170), 1 female (no number), ex Calomys callosus (Rengger 1830; CML 7176), 2 males (no numbers), 2 females (no numbers), ex L. massoia (CML 2895), 1 male (no number), 1 female (no number), ex T. sponsorius (CML 7159, released); El Ceibal Chico, $4 \mathrm{~km}$ al E de la rotonda de San Isidro de Lules por ruta provincial 321 y $1.5 \mathrm{~km}$ al S, por calle Julio C. Berrizbeitia, 1 female (no number), ex Akodon tucumanensis J. A. Allen 1901 (released); Lagunas de Huaca Huasi (Cumbres Calachaquíes), 1 female (no number), ex $A$. andina (CML 11762); Las Tipas, Parque Biológico Sierra de San Javier, 1 male (no number), ex Graomys domorum (Thomas 1902; CML 5986); Los Chorrillos 13 km NO, límite norte estancia Los Chorrillos, 1 male (no number), ex A. spegazzinii (CML 6466); Pie de la Cuesta a Chasquivil, $5 \mathrm{~km}$ de la Hoyada sobre Río Hoyada, 2 females (no numbers), ex Abrothrix illutea Thomas 1925 (CML 11791), O. brendae (CML 7279); Piedra Blanca, 1 female (no number), ex Akodon alterus Thomas 1919 (CML 7275); Reserva La Florida, 7 km O lbatín, sobre Río Pueblo Viejo, 3 males (no numbers), 2 females (no numbers), ex A. simulator (CML 6087), 1 male (no number), ex E. legatus (CML 5981), 1 female (no number), ex O. brendae (SNOMNH 34347); Reserva Provincial Aguas Chiquitas, sobre Río Aguas Chiquitas, 1 male (no number), 1 female (no number), ex A. caenosus (CML 11942), 1 male (no number), 1 female (no number), ex A. spegazzinii (CML 11942), 1 male (no number), ex C. venustus (CML 11949), 1 male (no number), 2 females (no number), ex $O$. flavescens (CML 11944); Río Grande, 5 km al S de El Siambón, 1 male (no number), ex O. brendae (CML 9653), 1 female (no number), ex Thylamys cinderella (Thomas 1902; CML 7775); Río Nio, 4 km al O, camino hacia Alto de Medina, 1 female (no number), ex C. boliviae (SNOMNH 35288); Santa Cruz, $10 \mathrm{~km}$ al $\mathrm{S}$ de Tafí del Valle, 8 males (no numbers), 10 females (no numbers), ex P. osilae (SNOMNH
30102); Tapia, cruce de ruta 9 y Río Tapia, 1 female (no number), ex O. brendae (CML 11558). Brazil: Serra do Cipo, Minas Gerais, 1 male (BMNH 1948-516), ex Nectomys squamipes Brants 1827 (unknown number). Paraguay: Sapucay, 1 lectotype female (BMNH 1923-615), ex Didelphis aurita Wied-Neuwied 1826 (unknown number; originally identified as Didelphis azarae Tschudi 1845).

Additional Records. Catamarca: Otro Cerro, Rancho de los Crisho, ex Rodentia (Hopkins and Rothschild 1956). Jujuy: Laguna La Brea, 25 km antes de Palma Sola, ex E. legatus (Lareschi et al. 2003); Villa Carolina, Río Lavallén, a unos 20 km al E de San Pedro de Jujuy, ex Holochilus chacarius Thomas 1906 (originally cited as Holochilus balnearum; Hopkins and Rothschild 1956). Salta: $12.6 \mathrm{~km} \mathrm{O}$ de Piquirenda Viejo, ex Chrotopterus auritus (Autino et al. 2009); El Quebrachal, ex G. griseoflavus, M. maenas (originally cited as M. australis) and Rattus rattus Linnaeus 1758 (Hopkins and Rothschild 1956); J. V. González, ex Galea leucoblephara Burmeister 1861 (originally cited as G. musteloides; Hopkins and Rothschild 1956). Santiago del Estero: El Quemado, ex A. tucumanensis; Las Carpas, ex G. griseoflavus, C. venustus (originally cited as Hesperomys venustus) and $M$. jayat (originally cited as $M$. australis); not specific locality, ex G. griseoflavus (Hopkins and Rothschild 1956). Tucuman: Cerro San Javier, a unos $20 \mathrm{~km}$ al $O$ San Miguel de Tucuman, ex L. massoia (originally cited as $L$. crassicaudata) and $O$. brendae (originally cited as $O$. destructor); not specific locality, ex Rattus sp. (Del Ponte 1977).

Remarks. Traditionally two subspecies, Craneopsylla minerva minerva (Rothschild, 1903) and Craneopsylla minerva wolffhuegeli (Rothschild, 1909) are recognized, differentiated by the number of spines present in genal ctenidium (Hopkins and Rothschild 1956). Del Ponte (1977) treated both as valid species, C. minerva and C. wolffhuegeli. Despite this, other authors have continued to treat them as subspecies (Beaucournu et al. 2014; Lareschi et al. 2016). Here, we consider C. m. minerva and C. m. wolffhuegeli as synonyms, based on the study of the morphology of our collected specimens and their comparison with specimens from other collections, which include an allotype and lectotypes. We have determined that the character traditionally used to differentiate them as subspecies is highly variable and presents intermediate states. We have registered individuals with four, five, six or seven genital spines, and even in some specimens the number of spines can vary on each side. In addition, no differences were found in the genitalia of the males of both subspecies.

Twenty one new flea-host associations were recorded with following hosts: L. massoia (Didelphimorphia, Didelphidae), A. spegazzinii (López-Berrizbeitia et al. 2013b), A. andina, A. illutea, A. budini, A. lutescens, A. simulator, A. tucumanensis, C. boliviae, C. callosus, C. venustus, E. legatus, G. chacoensis, $G$. domorum, O. brendae, O. flavescens, O. paramensis, P. caprinus, P. osilae, T. primus, and T. wolffsohni (Rodentia, Cricetidae).

In the review of fleas of Argentina, Lareschi et al. (2016) mistakenly mentioned as host of Craneopsylla minerva to 
Holochilus vulpinus (Brants 1827) for the locality of "Villa Carolina" (Jujuy Province), but this species of rodent is not in NOA, therefore it corresponds to $H$. chacarius. Regarding the host mentioned by Hopkins and Rothschild (1956) as H. venustus for the locality "Las Carpas" (Santiago del Estero Province), it was cited by Lareschi et al. (2016) as Calomys musculinus (Thomas, 1913), but it corresponds to C. venustus.

Genus Nonnapsylla Wagner 1938

Nonnapsylla rothschildi Wagner 1938

General distribution. Argentina, Bolivia, Chile, and Perú (Beaucournu et al. 2014; Lareschi et al. 2016).

Distribution in Argentina. It is only found in the Jujuy Province (Lareschi et al. 2016).

Specimens Examined (9). Argentina. Jujuy: Cuesta del Hurón, $29 \mathrm{~km}$ al O de Cieneguillas, sobre ruta provincial 64, 1 male (no number), 5 females (no numbers), ex Octodontomys gliroides (P. Gervais and d'Orbigny 1844; CML 7143, 7144); Curques, $24 \mathrm{~km}$ al $\mathrm{N}$ de Susques sobre ruta 74, 1 female (no number), ex E. puerulus (CML 7974). Bolivia: Río Yapacani, Santa Cruz, 1 female lectotype (BMNH 1923-615), ex Opisthocomus hoazin (Muller 1776; unknown number). Peru: Puno, 4 km NO Pomata, 1 paratype female (BMNH 1957-239), ex Galea musteloides Meyen 1833 (unknown number).

Additional Records. Jujuy: Cuesta del Hurón, $29 \mathrm{~km}$ al O de Cieneguillas, sobre ruta provincial 64, ex Galea comes Thomas 1919 (originally cited as G. leucoblephara) and P.xanthopygus (Lareschi et al. 2011).

Remarks. This species was not recorded in this study, the specimens examined correspond to those deposited in collections. The recorded localities in Argentina belong to the Puna at an elevation close to $4000 \mathrm{~m}$. The recorded hosts are typical inhabitants of this environment as $O$. gliroides, the only octodontids distributed in the Puna, from the Jujuy to La Rioja (Verzi et al. 2015), or E. puerulus (Cricetidae), found in the Puna and High Andes in Jujuy, Salta, and Catamarca provinces (Lanzone et al. 2015). According to this, the presence of this species in other provinces of NOA is highly probable, so to increase the sampling effort in this type of habitat is fundamental.

Genus Plocopsylla Jordan 1931

Plocopsylla (Plocopsylla) chicoanaensis López-Berrizbeitia, Sanchez, Barquez, and Díaz 2018

General distribution. Endemic to Argentina (López-Berrizbetia et al. 2018).

Distribution in Argentina. Salta and Catamarca provinces (López-Berrizbetia et al. 2018).

Specimens Examined (21). Catamarca: Las Juntas, 1 male (CMLA 697), ex A. caenosus (MIC 94), 2 paratypes males (CMLA 689, 690), 1 paratype female (CMLA 691), ex A. spegazzinii (MIC 110, 121, 126), 3 males (CMLA 699, 700, 701), 4 females (CMLA 702, 703, 704, 705), ex A. spegazzinii (MIC 91, 108, 113, 121), 1 male (CMLA 706), ex Oligoryzomys sp. (MIC 204), 1 female (CMLA 698), ex P. osilae (MIC 79). Salta: Aproximadamente $15 \mathrm{~km}$ O Escoipe, sobre ruta provincial № 33,
1 male holotype (CMLA 687), 1 allotype female (CMLA 688), ex A. spegazzinii (SNOMNH 33007), 3 paratypes males (CMLA $692,694,695), 2$ paratypes females $(693,696)$, ex A. spegazzinii (CML 9236, 9240); 26 km noroeste de Santa Rosa de los Pastos Grandes, 1 female (CMLA 707), ex P. osilae (CML 7234).

Remarks. Plocopsylla (P.) chicoanaensis belongs to the complex 'angusticeps-lewisi'. The complex also comprises Plocopsylla (P.) angusticeps, $P$. (P.) lewisi, P. (P.) wilesi, P. (P.) silewi, and $P .(P$.$) linardii, all recorded in Argentina. Ploco-$ psylla (P.) linardii, recently described from San Juan Province, Argentina (Sanchez et al. 2015), is closest geographically to $P$. $(P$.$) chicoanaensis. The type locality of P$. $(P$.) chicoanaensis corresponds to the Monte Desert of Mountains and Isolated Valleys. The habitat in which the paratypes were collected corresponds to the montane forest stratum of the Yungas Forest ecoregion. The hosts recorded for $P$. $(P$.$) chicoanaensis belong to different tribes of rodents,$ including Akodontini (A. caenosus and A. spegazzinii), Phyllotini (P. osilae) and Oryzomyini (Oligoryzomys sp.); the record of these associations was probable because the other species of the complex were also found parasitizing species of these tribes (see Sanchez et al. 2015).

Plocopsylla (Plocopsylla) hastriteri López-Berrizbeitia, Sanchez, Barquez and Díaz 2018

General distribution. Endemic to Argentina (López-Berrizbetia et al. 2018).

Distribution in Argentina. It has only been recorded in one locality from La Rioja Province (López-Berrizbetia et al. 2018).

Specimens Examined (2). La Rioja: 8 km al NE del Cañón del Ocre, 1 male holotype (CMLA 708), 1 male paratype (CMLA 709), ex P. osilae (CML 13011).

Remarks. The type locality of $P$. $(P$.$) hastriteri corresponds$ to the Puna. This species was recorded on P. osilae, a species of the tribe Phyllotini, which coincides with the recorded hosts in other species of the genus, either to the same genus (Phyllotis) or, as $P$. (P.) pallas, collected on the genus Eligmodontia (Schramm and Lewis 1988).

\section{Plocopsylla (Plocopsylla) inti Johnson 1957}

General distribution. Perú (Johnson 1957) and Argentina (López-Berrizbetia et al. 2018).

Distribution in Argentina. This species is only found in one locality from Catamarca Province (López-Berrizbetia et al. 2018).

Specimens Examined (1). Catamarca: Paycuqui, 1 female (CMLA 710), ex Abrothrix andina (CML 9218).

Remarks. This species constitutes a new record for Argentina, extending its distribution $\sim 970 \mathrm{~km}$ southward. Johnson (1957) described P. (P.) inti from Tacna (Peru) in Phyllotis magister Thomas 1912 and $P$. xanthopygus; this new record represents the second one of the species after 60 years. The collection locality corresponds to the Puna. Plocopsylla $(P$. inti infesting Abrothrix andina, a new flea-host association (López-Berrizbeitia et al. 2018). 
Genus Tiarapsylla Wagner 1937

Tiarapsylla argentina Jordan 1942

General distribution. Endemic to Argentina (Lareschi et al. 2016).

Distribution in Argentina. Chubut, Jujuy, La Pampa, Mendoza, Santa Fe, and Tucuman provinces (Lareschi et al. 2016).

Specimens Examined. None.

Additional records. Jujuy: Pucará de Tilcara, ex Graomys o Bolomys. Tucuman: Los Cardones, ex Ctenomys sp. (Beaucournu and Castro 2003).

Remarks. Tiarapsylla argentina is endemic to Argentina (Lareschi et al. 2016). Other recorded hosts for this species in other provinces are: Ctenomys mendocinus Philippi 1869 and M. australis in Mendoza Province, and Reithrodon auritus (G. Fischer 1814) in Chubut Province (see Lareschi et al. 2016).

Family Rhopallopsyllidae

Subfamily Parapsyllinae

Genus Delostichus Jordan 1942

Delostichus talis (Jordan 1936)

General distribution. Endemic to Argentina (Smit 1987).

Distribution in Argentina. Buenos Aires, Chubut, La Pampa, Mendoza, Rio Negro, San Juan (Lareschi et al. 2016), and La Rioja provinces (López-Berrizbeitia et al. 2017); in this study it is added to Catamarca Province.

Specimens Examined (21). Catamarca: $21 \mathrm{~km}$ SO El Desmonte, 4 males (no numbers), ex M. maenas (SNOMNH 30232). La Rioja: Quebrada de Santo Domingo, $30 \mathrm{~km}$ SO de Jagüé, 6 males (CMLA 619, 620, 621; 3 specimens no numbers), 9 females (CMLA 613, 614, 615, 616, 617, 618; 3 specimens no numbers), ex Microcavia sp. (CML 13052, 13053). Rio Negro: Fortín Uno, 1 lectotype male (BMNH 1923-615), 1 allotype female (BMNH 1923-615), ex M. australis.

Remarks. This species is endemic to Argentina (Lareschi et al. 2016); being the rodents of the family Caviidae its main hosts (Smit 1987). However, others hosts, in provinces not belonging to NOA, are: G. griseoflavus (Cricetidae) from Rio Negro, T. barrerae (Octodontidae) from Mendoza, R. rattus (Muridae) from La Pampa, and in some carnivores as Conepatus chinga, Lycalopex griseus y L. gymnocercus from Mendoza (Smit 1987; Lareschi et al. 2016). Regarding to the species of Lycalopex, Teta et al. (2018) consider them as synonyms, but in this study both species are accepted as valid (Díaz and Lucherini 2006). The recorded localities in NOA correspond to the Puna with an elevation of $3000 \mathrm{~m}$, and to the Monte Desert of Mountains and Isolated Valleys with an elevation that exceeds $2000 \mathrm{~m}$.

\section{Genus Ectinorus Jordan, 1942}

Ectinorus (Ectinorus) budini (Jordan and Rothschild 1923)

General distribution. Argentina (Lareschi et al. 2016).

Distribution in Argentina. It is only found in one locality in Catamarca Province (Lareschi et al. 2016).
Specimens Examined (2). Catamarca: Otro Cerro, 1 lectotype male (BMNH 1923-614), ex Andinomys edax Thomas 1902 (unknown number), 1 paralectotype male (BMNH 1923-615), ex P. xanthopygus (unknown number; originally identified as Phyllotis arenarius Thomas 1902).

Remarks. During this study, specimens of this species were not collected; the examined specimens correspond to those deposited specimens in the BMNH. Female is unknown. The females recorded of the type series (Jordan and Rothschild 1923) and described within this species were misidentified, they could be related to Ectinorus (Ectinorus) simonsi (Smit 1987).

\section{Ectinorus (Ectinorus) disjugis Jordan 1942}

General distribution. Argentina and Perú (Smit 1987).

Distribution in Argentina. It is only found in one locality in Jujuy Province (Lareschi et al. 2016).

Specimens Examined (2). Argentina. Jujuy: El Chaguaral, Villa Carolina, 1 holotype female (BMNH 1923-615), ex Ctenomys juris Thomas 1920 (unknown number; originally identified as Ctenomys mendocinus juris Cabrera 1961). Peru: Cailloma, Arequipa, 1 female (BMNH 1948-97), ex Rodentia (unknown number).

Remarks. This species was not collected in this study, the examined specimens correspond to those deposited in the $\mathrm{BMNH}$. Male is unknown. The only recorded locality in NOA corresponds to Dry Chaco ecoregion.

\section{Ectinorus (Ectinorus) hapalus (Jordan 1942)}

General distribution. Endemic to Argentina (Smit 1987).

Distribution in Argentina. Buenos Aires, Chubut, Mendoza, Neuquén, San Luis, and Santa Cruz provinces (Lareschi et al. 2016); in this study it is added to La Rioja Province.

Specimens Examined (3). La Rioja: $2 \mathrm{~km}$ al S pasando Río de La Punta sobre ruta provincial № 7, 1 male (no number), ex G. chacoensis (CML 12948). Mendoza: Santa Rosa, 1 lectotype male (BMNH 1940-217), 1 paralectotype female (BMNH 1940-217), ex nest of G. griseoflavus.

Remarks. This species is endemic from Argentina (Lareschi et al. 2016), being this record the first for NOA, extending its geographical distribution $\sim 600 \mathrm{~km}$ northward; the nearest locality is Santa Rosa (Mendoza Province). The NOA record corresponds to the Monte Desert of Mountains and Isolated Valleys, at an elevation $1000 \mathrm{~m}$. Graomys chacoensis represents a new association flea-host. Others rodent hosts are: Abrothrix longipilis (Waterhouse 1837) in the Chubut, Abrothrix olivacea (Waterhouse 1837) in Neuquén and Santa Cruz, and Akodon azarae (J. B. Fischer 1829; originally cited as A. arenicola Thomas 1917) in Buenos Aires (Sanchez and Lareschi 2013, 2014a; Lareschi et al. 2016).

\section{Ectinorus (Ectinorus) nomisis Smit 1987}

General distribution. Argentina and Chile (Beaucournu et al. 2014; Lareschi et al. 2016).

Distribution in Argentina. It is only found in one locality in Jujuy Province (Lareschi et al. 2016). 
Specimens Examined (1). Jujuy: 5 km NE de Humahuaca, 1 holotype male (BMNH 1971-662), ex O. gliroides (unknown number).

Remarks. During this study, this species was not recorded; the specimen examined corresponds to a male deposited in the BMNH from Argentina. The collecting locality is placed in the Puna at $\sim 4000 \mathrm{~m}$.

Ectinorus (E.) nomisis is closely related to $E$. $(E$.) simonsi. Beaucournu et al. (2013), based on the finding of three males with intermediate characters between these two species, raised the possibility that $E$. $(E$.) nomisis could be a subspecies of $E(E$.$) simonsi. The examined specimen from Jujuy$ has all characters belonging to this species, therefore there is no doubt about its identity. It is necessary to increase the sample number of this species that may allow the study of morphology in order to study variation among them.

Ectinorus (Ectinorus) pilosus Beaucournu and Castro 2002

General distribution. Argentina and Chile (Beaucournu et al. 2014; Lareschi et al. 2016).

Distribution in Argentina. It is only found in one locality in Catamarca Province (Lareschi et al. 2016).

Specimens Examined. None.

Additional Records. Catamarca: Santa María Department, ex Ctenomys knighti Thomas 1919 (originally cited as Ctenomys sp.; Beaucournu and Castro 2002; Lareschi et al. 2016).

Remarks. During this study, this species neither was recorded nor revised specimens in systematic collection. This species was recorded for the first time in Argentina in the Monte Desert of Mountains and Isolated Valleys at an elevation of $\sim 2000 \mathrm{~m}$ (Beaucournu and Castro 2002); later Beaucournu et al. (2013) published the second record of the species parasitizing Ctenomys sp. in Chile. It is probable that $E$. (E.) pilosus could have a preference for this genus, although records are very scarce (Beaucournu et al. (2013)).

\section{Ectinorus (Panallius) galeanus (Jordan 1939)}

General distribution. Endemic to Argentina (Smit 1987).

Distribution in Argentina. Buenos Aires, Mendoza, Neuquen, Rio Negro, San Juan, San Luis, and Santiago del Estero provinces (Lareschi et al. 2016).

Specimens Examined (2). San Juan: Las Casuarinas, 1 lectotype male (BMNH 1940-217), 1 allotype female (BMNH 1940-217) ex G. leucoblephara (unknown number).

Additional Records. Santiago del Estero: El Ojito, ex $L$. maximus; El Quemado, ex Akodon [boliviensis] tucumanensis; Las Carpas, ex G. chacoensis (originally cited as G. griseoflavus) and M. jayat (originally cited as M. australis; Smit 1987; Lareschi et al. 2016).

Remarks. This species was not recorded in this study, the examined specimens correspond to those deposited in the BMNH. Ectinorus (Panallius) galeanus is endemic to Argentina and was recorded parasitizing Akodon dolores Thomas 1916 in Neuquen (Lareschi et al. 2016). The hosts of this species are diverse, including rodents of different habits belong- ing to the families Cricetidae (two tribes) and Caviidae. The host cited from Santiago del Estero (locality "El Quemado") is doubtful because $A$. tucumanensis is not distributed in the province. The species is distributed in arid environments, Dry Chaco and Monte Desert of Mountains and Isolated Valleys.

Genus Tetrapsyllus Jordan 1931

Tetrapsyllus (Phylliver) bleptus (Jordan and Rothschild 1923)

General distribution. Argentina, Peru, and Chile (Smit 1987; Beaucournu et al. 2014).

Distribution in Argentina. Catamarca, Jujuy, Mendoza, Neuquen (Lareschi et al. 2016), La Rioja, Salta, and Tucuman provinces (López-Berrizbeitia et al. 2019).

Specimens Examined (22). Catamarca: Otro Cerro, 1 holotype female (BMNH 1923-615), 1 paratype female (BMNH 1923-615), ex R. auritus (unknown number; originally identified as Reithrodon caurinus Thomas 1920). Jujuy: Quebrada Seca, Alfarcito, $10 \mathrm{~km}$ al O de Tilcara, 1 male (no number), ex Phyllotis sp. (CML 12308). LA RIOJA: Puesto Tres Piedras, 2 males (no numbers), ex Akodon sp. (CML 12900); Quebrada de Santo Domingo $30 \mathrm{~km}$ al SO de Jagué, 1 female (no number), ex P. xanthopygus (CML 13046). Mendoza: Puesto "Pugin", Algarrobito, 1 male (BMNH 1959-683), ex Rodentia (unknown number). Salta: Finca Barba Yaco, 8.5 km SE Ojo de Agua, 1 female (no number), ex A. simulator (SNOMNH 29996). Tucuman: Ciénaga Escondida, 1 male (no number), ex A. spegazzinii (released), 1 male (no number), 1 female (no number), ex $P$. xanthopygus (released); La Olorosa, 1 female (no number), ex P. osilae (released); Los Chorrillos $13 \mathrm{~km} \mathrm{NO}$ límite norte estancia Los Chorrillos, 1 female (no number), ex A. simulator (CML 9053).

Additional Records. Jujuy: El Chaguaral, ex C. juris (originally cited as C. mendocinus juris); Reserva Provincial Olaroz-Cauchari, ex A. albiventer (Smit 1987; Lareschi et al. 2010).

Remarks. The new flea-host associations recorded are: Tetrapsyllus (Phylliver) bleptus with A. simulator, A. spegazzinii, and P. osilae (López-Berrizbeitia et al. 2019); another recorded host is G. griseoflavus from Mendoza (Smit 1987). In the study area, the species was recorded in Monte Desert of Mountains and Isolated Valleys, Dry Chaco, High Andes, Puna, Yungas, and in the ecotone between Yungas and High Andes.

Tetrapsyllus (Tetrapsyllus) spegazzinii Lopez-Berrizbeita, Hastriter, Barquez and Diaz 2019.

General distribution. Argentina (López-Berrizbeitia et al. 2019).

Distribution in Argentina. It is only recorded in Salta Province (López-Berrizbeitia et al. 2019).

Specimens Examined (5). Salta: 15 kmW Escoipe, on Provincial road No. 33, 1 holotype male (CMLA 818), ex A. spegazzinii (SNOMNH 33007), 1 allotype female (CMLA 819), 1 paratype male (CMLA 820) ex A. spegazzinii (CML 9236); Finca Barba Yaco, $8.5 \mathrm{~km}$ SE Ojo de Agua, 1 paratype male (CMLA 821), 1 paratype female (CMLA 822) ex A. simulator (CML 9050, SNOMNH 33147). 
Remarks. The localities of examined specimens belong to the Monte Desert of Mountains and Isolated Valleys and Yungas.

\section{Subfamily Rhopalopsyllinae}

Genus Polygenis Jordan 1939

Polygenis (Neopolygenis) pradoi (Wagner 1937)

General distribution. Argentina, Brazil, and Colombia (Smit 1987).

Distribution in Argentina. Buenos Aires (Lareschi et al. 2016) and Misiones provinces (Urdapilleta et al. 2019); and in this study, it is included in Catamarca and Salta provinces.

Specimens Examined (5). Argentina. Catamarca: Las Juntas, 2 females (no numbers), ex A. spegazzinii (MIC 86, 119). Salta: Aproximadamente $15 \mathrm{~km} \mathrm{O}$ de Escoipe, sobre ruta provincial № 33, 1 female (no number), ex A. spegazzinii (SNOMNH 33007). Brazil: Brasilien, Nova Teutonia, Catharina, 1 topotype male (BMNH 1956-476), ex Rodentia (unknown number), 1 topotype female (BMNH 1956-476), unknown host.

Remarks. Here, a new flea-host association, $P$. (N.) pradoiA. spegazzinii, is recorded. Others recorded hosts in Argentina are: Didelphis albiventris Lund 1840, A. azarae, Oligoryzomys nigripes (Olfers 1818), Oxymycterus rufus (G. Fischer 1814), and Scapteromys aquaticus Thomas 1920 (Lareschi et al. 2016). The records of this species extend its geographical distribution $\sim 1550 \mathrm{~km}$ northwest of Argentina. In order to complete the gap between the records of Buenos Aires Province and NOA, is necessary to increase the sampling efforts of Polygenis (Neopolygenis) pradoi. Also, the presence of this species in Ecuador, Peru, and Bolivia is highly probable due to its location among records from Colombia, Brazil, and Argentina.

\section{Polygenis (Neopolygenis) puelche Del Ponte 1963}

General distribution. Endemic to Argentina (Lareschi et al. 2016).

Distribution in Argentina. Buenos Aires, La Pampa, Mendoza, and Tucuman provinces (Lareschi et al. 2016), and in this study, it is included in Catamarca and Salta provinces.

Specimens Examined (16). Catamarca: $22 \mathrm{~km}$ al SE de Villa de Escaba sobre ruta provincial № 9, 1 female (no number), A. spegazzinii (CML 12356); $3.4 \mathrm{~km}$ al $\mathrm{S}$ de la unión entre las rutas provinciales 18 y 9 , sobre ruta provincial № 18,2 males (no numbers), 2 females (no numbers), ex A. simulator (CML 7219), 3 females (no numbers), 1 male (no number), ex $A$. lutescens (SNOMNH 37302, 37308). Salta: Aguas Blancas, Estación de Aforo a $30 \mathrm{~m}$ del puente internacional sobre ruta provincial $\mathrm{N}^{\circ} 19$, a orillas del Río Bermejo, 1 male (no number), ex Akodon simulator (CML 11014); $2 \mathrm{~km}$ al $\mathrm{N}$ y $6 \mathrm{~km}$ al O de Metán, sobre río Las Conchas, 1 female (no number), ex A. simulator (CML 12349). Tucuman: $26 \mathrm{~km}$ al S de San Pedro de Colalao sobre ruta provincial 364, 1 female (no number), ex A. simulator (SNOMNH 33188); Los Chorrillos $13 \mathrm{~km} \mathrm{NO}$, límite norte estancia Los Chorrillos, 1 male (no number), 1 female (no number), ex A. simulator (CML 9053); Río Nío, 4 $\mathrm{km}$ al $\mathrm{O}$, camino hacia Alto de Medina, 2 males (no numbers), ex O. brendae (CML 4475, 4480).

Additional Records. Tucuman: Cerro San Javier, unknown host (Smit 1987).

Remarks. This species is endemic to Argentina (Lareschi et al. 2016). In this study, three new flea-host associations are recorded: $P$. (N.) puelche with A. simulator, A. spegazzinii, and $A$. lutescens. Others recorded hosts are: L. crassicaudata, A. azarae, Calomys laucha (G. Fisher 1814), C. musculinus, Ctenomys talarum Thomas 1898, O. rufus, and O. nigripes in Buenos Aires; G. griseoflavus in Buenos Aires and La Pampa; and A. dolores in Mendoza (Lareschi et al. 2016. The distribution of the species extends $\sim 300 \mathrm{~km}$ to the west and $\sim 500 \mathrm{~km}$ to the north from of the nearest locality belonging to the Trancas Department, Tucuman Province.

Polygenis (Polygenis) acodontis (Jordan and Rothschild 1923).

General distribution. Argentina, Brazil, and Venezuela (Smit 1987).

Distribution in Argentina. Buenos Aires, Catamarca, Cordoba, Jujuy, La Pampa, Salta, Tucuman (Lareschi et al. 2016), and La Rioja provinces (López-Berrizbeitia et al. 2017); in this study the Santiago del Estero Province is added.

Specimens Examined (92). Catamarca: Otro Cerro, 1 lectotype male (BMNH 1923-615), ex A. simulator (unknown number), 1 paralectotype female (BMNH 1923-615), Homo sapiens Linnaeus 1758; $21 \mathrm{~km}$ SO El Desmonte, 1 male (no number), ex M. maenas (SNOMNH 30232); $22 \mathrm{~km}$ al SE de Villa de Escaba sobre ruta provincial № 9, 1 male (no number), ex A. glaucinus (CML 12347), 1 male (no number), 2 females (no numbers), ex A. spegazzinii (CML 12356, 12360); 3.4 km al $\mathrm{S}$ de la unión entre las rutas provinciales 18 y 9 , sobre ruta provincial № 18, 1 female (no number), ex A. lutescens (SNOMNH 37307); Estancia Narváez, 5.5 km N La Chacritas en ruta provincial 1, 3 males (no numbers), 1 female (no number), ex A. spegazzinii (CML 7198); Las Juntas, 1 male (no number), 4 females (no numbers), ex A. simulator (MIC $66,104,130,182,207), 3$ males (no numbers), 5 females (no numbers) ex A. spegazzinii (MIC 86, 113, 119, 121, 173), 1 male (no number), ex Necromys lactens (Thomas 1918; MIC 64), 3 females (no numbers), ex Oligoryzomys sp. (MIC 117, 170, 201), 1 male (no number), 1 female (no number) ex $P$. osilae (MIC 180, 181). Jujuy: Arroyo Los Matos, 7 km N de Las Capillas, 3 females (no numbers), ex A. budini (CML 12340), 2 females (no numbers), ex C. venustus (2 released), 1 female (no number), ex O. brendae (CML 12372), 1 male (no number), 1 female (no number), ex O. paramensis (CML 12364), 1 female (no number), ex T. sponsorius (released); Río Blanco, $9 \mathrm{~km}$ SO, San Antonio, 1 female (no number), ex O. brendae (CML 9550); Río Tiraxi, $1.5 \mathrm{~km}$ al E de Tiraxi, sobre ruta provincial № 29, 1 male (no number), ex O. brendae (CML 9537). La Rioja: Cuesta La Cébila, $22 \mathrm{~km}$ al NO de Chumbicha, sobre ruta 60, 1 male (CMLA 674), ex A. glaucinus (CML 3751). Salta: $3 \mathrm{~km}$ al $\mathrm{N}$ de Potrerillos sobre ruta provincial № 6, 10 males 
(no numbers), 11 females (no numbers), ex A. simulator (CML 9037, SNOMNH 29992); 2 km al N y 6 km al O de Metán, sobre Río Las Conchas, 1 female (no number), ex A. caenosus (CML 12342), 1 female (no number), ex A. puer (CML 12345), 2 females (no numbers), ex A. simulator (CML 12349); $3.5 \mathrm{~km}$ al $\mathrm{O}$ de Metán, 2 females (no numbers), ex A. simulator (CML 12352); Finca Barba Yaco, 8.5 km SE Ojo de Agua, 2 males (no numbers), 1 female (no number), ex $A$. simulator (SNOMNH 29995, 29996, 33147), 2 females (no numbers), ex O. brendae (CML 9572), 1 male (no numbers), 2 females (no numbers), ex P. xanthopygus (SNOMNH 30198); Pintascayo, Campamento Lima (Propiedad de GMF S.A), 1 male (no number), ex A. cf. fumeus (MMD 5172); Río Los Sauces, 12 km NO del Jardín, ruta $6 \mathrm{~km} \mathrm{110,2}$ males (no numbers), 1 female (no number), ex C. venustus (LIF 190). Santiago del Estero: La Puerta, $27 \mathrm{~km}$ al SE de Las Termas de Río Hondo, sobre ruta Nacional № 9, 2 females (no numbers), ex A. dolores (CML 12343). Tucuman: $1.9 \mathrm{~km}$ NE Hualinchay sobre ruta provincial 311, 1 male (no number), ex P. osilae (CML 8085); Dique San Ignacio, 1 female (no number), ex T. sponsorius (CML 7159); Los Chorrillos 13 km NO, límite norte estancia Los Chorrillos, 1 male (no number), ex $A$. simulator (CML 9053), 1 female (no number), ex Akodon sp. (CML 6466), 1 male (no number), ex T. sponsorius (CML 7814); Reserva Provincial Aguas Chiquitas, sobre Río Aguas Chiquitas, 1 male (no number), 1 female (no number), ex C. venustus (CML 11945, 11947).

Additional Records. Catamarca: Otro Cerro, ex A. alterus. Jujuy: El Chaguaral, ex C. juris (originally cited as C. $m$. juris; Johnson 1957; Smit 1987; Lareschi et al. 2016).

Remarks. In this study, P. (P.) acodontis infesting A. budini, A. glaucinus, A. lutescens, N. lactens, O. brendae, and P. osilae, all constitute new flea-host associations, and it was also recorded on P. xanthopygus (López-Berrizbeitia et al. 2013b). The localities from NOA belong to Dry Chaco, Yungas, and Monte Desert of Mountains and Isolated Valleys.

Polygenis (Polygenis) bohlsi (Wahlgren 1901)

Polygenis (Polygenis) bohlsi bohlsi (Wahlgren 1901)

General distribution. Argentina, Bolivia, Brazil, Colombia, Ecuador, French Guiana, Paraguay, Peru, and Venezuela (Smit 1987).

Distribution in Argentina. Buenos Aires, Chaco, Cordoba, Corrientes, and Mendoza provinces (Lareschi et al. 2016); in this study, La Rioja Province is included.

Specimens Examined (4). Buenos Aires: Chivilcoy, 1 male (BMNH 1962-699), 1 female (BMNH 1962-699), ex C. laucha (unknown number). La Rioja: Ulapes, $1 \mathrm{~km}$ al $\mathrm{O}$ de la plaza principal de Ulapes, 2 females (no numbers), ex G. chacoensis (CML 12991).

Remarks. The association P. (P.) b. bohlsi-G. chacoensis is new. Moreover, this species was recorded on others rodents in Argentina such as A. azarae, C. aperea, S. aquaticus, A. dolores, G. griseoflavus, Mus musculus Linnaeus 1758, and Deltamys kempi Thomas 1917 (Lareschi et al. 2016). The record from La Rioja corresponds to Dry Chaco and extends the geographical distribution of the species $\sim 360 \mathrm{~km}$ northwest of Argentina.

Polygenis (Polygenis) byturus (Jordan and Rothschild 1908)

General distribution. Argentina and Bolivia (Smit 1987).

Distribution in Argentina. Antarctica and South Atlantic Islands, Buenos Aires, Cordoba, Jujuy, La Pampa, Rio Negro, Salta, Santa Fe, San Luis, Santiago del Estero, Tierra del Fuego, and Tucuman provinces (Lareschi et al. 2016); in this study the Catamarca and La Rioja provinces are added.

Specimens Examined (20). Catamarca: Estancia Narváez, $5.5 \mathrm{~km} \mathrm{~N}$ La Chacritas en ruta Provincial 1, 1 female (no number), ex A. alterus (SNOMNH 32997). La Rioja: 2 km al E de Malanzán, camping El Descanso, 1 male (no number), 1 female (no number), ex Akodon sp. (CML 12897); 26 km SO Quimilo, 1 female (no number), ex $A$. dolores (SNOMNH 36034); Ambil, $23 \mathrm{~km}$ al $S$ de Catuna, 2 females (no numbers), ex G. chacoensis (CML 12983); Chepes, puesto La Escondida, $42 \mathrm{~km}$ al S de Chepes, 1 female (no number), ex G. chacoensis (CML 12990); Olta, Dique de Olta, 2 males (no numbers), 2 females (no numbers) ex G. chacoensis (CML 12962); Ulapes, $1 \mathrm{~km}$ al $\mathrm{O}$ de la plaza principal de Ulapes, 1 female (no number), ex P. xanthopygus (CML 13037). Salta: Finca Chato Méndez, 1 male (no number), 4 females (no numbers), ex $C$. callosus (CLH 1, 2). Santa Fe: Las Rosas, 1 male lectotype (BMNH 1923-615), 1 female allotype (BMNH 1923-615), ex L. crassicaudata (unknown number). Santiago del Estero: La Puerta, $27 \mathrm{~km}$ al SE de Las Termas de Río Hondo, sobre ruta Nacional № 9, 1 male (no number), ex G. chacoensis (CML 12397).

Additional Records. Jujuy: not specific locality, ex H. chacarius (originally cited as Holochilus [brasiliensis] vulpinus); El Chaguaral, ex C. juris (originally cited as Ctenomys [mendocinus] juris; Smit 1987). Salta: Cerillos, not specific locality, ex G. leucoblephara (originally cited as G. musteloides); El Quebrachal, ex G. leucoblephara (originally cited as G. musteloides), G. griseoflavus, R. rattus; J. V. González, ex G. leucoblephara (originally cited as G. musteloides; Smit 1987). Santiago del Estero: not specific locality, ex G. chacoensis (originally cited as G. griseoflavus); El Ojito, ex L. maximus; El Quemado, ex Akodon (boliviensis) tucumanensis, C. musculinus (originally cited as Hesperomys murillus); Las Carpas, ex C. venustus (originally cited as Hesperomys venustus), G. chacoensis (originally cited as G. griseoflavus), M. jayat (originally cited as M. australis); Pozo Betbeder, ex R. rattus (Smit 1987). Tucuman: Taco Ralo, unknown host (Smit 1987).

Remarks. The longitude degrees of the locality La Rosas (Santa Fe Province) were corrected. The host cited from Santiago del Estero (locality "El Quemado") is doubtful because $A$. tucumanensis is not distributed in the province. In this study, new flea-host associations were recorded: $P$. $(P$.) byturus with A. alterus, A. dolores, $C$. callosus and $P$. xanthopygus. The species is distributed in all provinces of NOA except Tucuman, although the presence of this species is highly probable. The ecoregions of the localities correspond to the Yungas and Dry Chaco. 
Polygenis (Polygenis) platensis (Jordan and Rothschild 1908).

General distribution. Argentina, Bolivia, Brazil, Chile, and Uruguay (Smit 1987).

Distribution in Argentina. Buenos Aires, Cordoba, Chubut, Entre Rios, Jujuy, La Pampa, La Rioja, Mendoza, Rio Negro, Salta, San Juan, San Luis, Santa Cruz, and Santiago del Estero (Lareschi et al. 2016) and Misiones provinces (Urdapilleta et al. 2016).

Specimens Examined (18). Buenos Aires: Chivilcoy, 1 male (BMNH 1944-88), ex A. azarae (originally cited as $A$. arenicola; unknown number); La Plata, 1 holotype female (BMNH 1923-615), ex Ctenomys sp. (unknown number); not specific locality, 1 male (BMNH 1923-615), ex Didelphis sp. (unknown number). La Rioja: $2 \mathrm{~km}$ al $\mathrm{S}$ de la entrada al Parque Geológico Sanagasta, sobre RN 75, 1 male (no number), 1 female (no number), ex $G$. chacoensis (CML 13001, 13002), 1 male (no number), ex P. osilae (CML 13015), 1 male (no number), ex P. xanthopygus (CML 13015); 4 km al O de Anillaco, Reserva Aguada de las Alturas, 1 male (CMLA 605), ex A. glaucinus (CML 9767); Ulapes, $1 \mathrm{~km}$ al $O$ de la plaza principal de Ulapes, 4 females (3 CMLA 622, 623, 624; 1 no number), ex $G$. chacoensis (CML 12991, 12992), 2 males (CMLA 625, 626), 2 females (CMLA 627, 628), ex G. griseoflavus (CML 13007). Mendoza: not specific locality, 1 holotype male (BMNH 1940-217), 1 paratype female (BMNH 1940-217), ex $M$. australis (unknown number).

Additional Records. Jujuy: San Pedro, unknown host. La Rioja: Guayapa, 13 km SO de Patquía cerca de la ruta 150, unknown host. Salta: Rosario de Lerma, G. leucoblephara (Smit 1987).

Remarks. Traditionally two subspecies of this species are recognized: $P_{\text {. }}\left(P_{\text {. }}\right) p$. platensis and $P_{\text {. }}\left(P_{\text {. }}\right) p$. cisandinus. Lareschi and Linardi (2009), through the review of type specimens and the diagnostic characters, questioned their validity of the subspecies and consider them as synonyms. This study follows Lareschi and Linardi (2009) and considers Polygenis (Polygenis) platensis as valid species.

According to the geographic coordinates in Smit (1987), the locality Guayapa (La Rioja Province) was wrongly placed at approximately $3 \mathrm{~km} \mathrm{~N}$ of El Milagro, but in this study is relocated to $\sim 180 \mathrm{~m} \mathrm{SE}$ of that site, next route 150 and $13 \mathrm{~km}$ SW Patquia (corrected coordinates: $-29^{\circ} 51^{\prime} 41.18^{\prime \prime} \mathrm{S},-67^{\circ} 14^{\prime} 22.99^{\prime \prime} \mathrm{W}$ ). López-Berrizbeitia et al. (2013b) cited as host to A. simulator, but following to Coyner et al. (2013) the species belong to A. glaucinus. López-Berrizbeitia et al. (2017) reported a new fleahost association from Ulapes, Polygenis (P.) platensis-G. chacoensis. The examined specimen collected from the genus Didelphis from Buenos Aires, would correspond to Didelphis albiventris, because it is the only species of the genus present in this province.

Polygenis (Polygenis) rimatus (Jordan 1932)
General distribution. Argentina, Brazil, Paraguay, and Perú (Smit 1987).

Distribution in Argentina. Buenos Aires, Chubut, Formosa, La Rioja, Misiones, Neuquen, San Juan, Santiago del Estero (Lareschi et al. 2016), and Salta provinces (Smit 1987).

Specimens Examined (3). Argentina. Salta: Gran Chaco, 1 paratype female (BMNH 1923-615), ex D. albiventris (unknown number; originally identified as Didelphis azarae Tschudi 1845). Paraguay: Sapucay, 1 holotype male (BMNH 1923-615), 1 paratype female (BMNH 1923-615), ex D. albiventris (unknown number; originally identified as $D$. azarae).

Additional Records. La Rioja: not specific locality, ex Cavia aperea (Smit 1987). Santiago del Estero: Not specific locality, ex M. jayat (originally cited as M. australis; Autino and Lareschi 1998).

Remarks. During this study, this species was not recorded, the examined specimens are those deposited in the BMNH. The host Cavia aperea was probably misidentified, because the presence of the genus Cavia (family Caviidae) in La Rioja province is unknown (Patton et al. 2015).

Polygenis (Polygenis) roberti (Rothschild 1905)

Polygenis (Polygenis) roberti beebei (Fox 1947)

General distribution. Argentina, Bolivia, Brazil; Colombia, Costa Rica, Ecuador, French Guiana, Panama, Peru, Surinam, and Venezuela (Smit 1987; Lareschi et al. 2016).

Distribution in Argentina. Jujuy (Lareschi et al. 2016), and Misiones provinces (Urdapilleta et al. 2019); in this study the Salta Province is added.

Specimens Examined (3). Argentina. Salta: $12.6 \mathrm{~km} \mathrm{O}$ de Piquirenda Viejo, 1 male (no number), ex E. legatus (CML 9694); Río Las Conchas, 2 km al N y 6 km al O de Metán, 1 female (no number), ex E. legatus (CML 9710). Bolivia: Buen Retiro, 1 female (BMNH 1955-277), ex Cuniculus paca (Linnaeus 1766; unknown number).

Additional Records. Jujuy: Laguna La Brea, $25 \mathrm{~km}$ antes de Palma Sola, ex E. legatus (Lareschi et al. 2016).

Remarks. The records cited in this study constitute the third one for Argentina and the second for NOA, extending the distribution $\sim 200 \mathrm{~km}$ north (in Jujuy Province) and $\sim 170$ $\mathrm{km}$ to the south (Salta Province). The records correspond to the Yungas Forests. The main hosts are rodents of the family Cricetidae, especially members of the tribe Oryzomyinii (Smit 1987).

Polygenis (Polygenis) tripus (Jordan 1933)

General distribution. Argentina, Bolivia, and Brazil (Smit 1987).

Distribution in Argentina. Buenos Aires, Salta (Lareschi et al. 2016), and Misiones provinces (Lareschi et al. 2019).

Specimens Examined (5). Salta: Hipólito Yrigoyen, 3 males (no numbers), ex A. tartareus (CLH 57); Rosario de Lerma, 1 lectotype male (BMNH 1923-615), 1 allotype female (BMNH 1923-615), ex G. leucoblephara (unknown number; originally identified as G. musteloides). 
Additional Records. Salta: not specific locality, ex G. leucoblephara (originally cited as G. musteloides; Smit 1987).

Remarks. The association recorded in this study, P. (P.) tripus-A. tartareus is a new flea-host association; in Argentina, others recorded hosts are: A. azarae, Oligoryzomys sp., Oxymycterys rufus, Phyllotis sp., S. aquaticus and Rattus norvegicus Berkenhout 1769 (Lareschi et al. 2016).

Genus Tiamastus Jordan 1939

Tiamastus cavicola (Weyenbergh 1881)

General distribution. Argentina, Bolivia, Chile, Ecuador, and Peru (Smit 1987; Beaucournu et al. 2014).

Distribution in Argentina. Buenos Aires, Catamarca, Cordoba, Jujuy, La Pampa, Mendoza, Rio Negro, Salta, and Santiago del Estero provinces (Lareschi et al. 2016).

Specimens Examined (19). Buenos Aires: Bonifacio, 1 male (BMNH 1923-615), ex C. aperea (unknown number). Jujuy: $3 \mathrm{~km}$ al E de Purmamarca por ruta nacional $N^{\circ} 52,6$ males (no numbers), 11 females (no numbers), ex M. maenas (CML 12400). Not specific locality: 1 lectotype female (BMNH 1923-615) ex C. aperea (unknown number; originally identified as Cavia leucopyga Brandt 1835).

Additional Records. Catamarca: La Merced, ex G. leucoblephara (originally cited as G. musteloides). Jujuy: El Chaguaral, ex C. juris. Salta: Rosario de Lerma; Cerillos (=Cerrillos), ex G. leucoblephara; Capital, unknown host (Smit 1987).

Remarks. The main hosts of this species are rodents of the family Caviidae (Smit 1987), but in Argentina it was recorded on others families of rodents: A. azarae (Cricetidae) and Ctenomys spp. (Ctenomyidae; Lareschi et al. 2016). The records of NOA correspond to Dry Chaco, Puna, and Yungas Forests.

\section{Tiamastus helicis Beaucournu and Castro 2003}

General distribution. Endemic to Argentina (Beaucournu and Castro 2003).

Distribution in Argentina. It is only found in one locality from Tucuman Province (Beaucournu and Castro 2003; Lareschi et al. 2016).

Specimens Examined. None.

Additional Records. Tucuman: Tapia, ex Ctenomys latro (Beaucournu and Castro 2003).

Remarks. This species is endemic from Argentina (Lareschi et al. 2016). During this study the species was not collected. The only known record corresponds to the Yungas Forests.

Tiamastus palpalis (Rothschild 1911)

General distribution. Argentina (Lareschi et al. 2016).

Distribution in Argentina. Catamarca, Jujuy, La Pampa, Mendoza, Santa Fe, Santiago del Estero, Tucuman (Lareschi et al. 2016), and La Rioja provinces (López-Berrizbeitia et al. 2017).

Specimens Examined (27). Catamarca: 9.2 km O Andalgalá, 2 males (no numbers), 3 females (no numbers), ex
Ctenomys sp. (SNOMNH 30256); Chumbicha, alrededores, 2 females (no numbers), ex Ctenomys sp. (CML 12409). La Rioja: $2 \mathrm{~km}$ al $\mathrm{S}$ pasando Río de La Punta sobre ruta provincial № 7, 1 male (no number), ex E. moreni (CML 12941); $700 \mathrm{~m}$ al $\mathrm{E}$ de ruta nacional 40, 1 female (CMLA 631), ex Ctenomys sp. (CML 11030); Anillaco, $500 \mathrm{~m}$ al $\mathrm{O}$ de la plaza de Anillaco, 7 males (1 CMLA 629, 6 no numbers), 11 females (5 CMLA 630, 632, 633, 634, 635, 6 no numbers), ex Ctenomys sp. (released).

Additional Records. Jujuy: El Chaguaral, cerca de Villa Carolina, ex C. juris. Santiago del Estero: not specific locality, ex Ctenomys brasiliensis (Johnson 1957; Smit 1987).

Remarks. This species is endemic from Argentina (Lareschi et al. 2016). The main hosts are rodents of the family Caviidae (Smit 1987); however, in this study, the species was collected on rodents of the families Cricetidae and Ctenomyidae. Others recorded hosts belong to mammals of the order Carnivora, in Mendoza (Smit 1987). Regarding to type host $C$. brasiliensis, it was misidentified because this species is not distributed in Argentina (Lareschi et al. 2016), probably the host correspond to Ctenomys argentinus, the only species of the genus present in Santiago del Estero. In NOA, most records correspond to the Monte Desert of Mountains and Isolated Valleys, and only two to the Dry Chaco.

Tiamastus plesius Jordan 1942

General distribution. Argentina and Chile (Smit 1987; Beaucournu et al. 2014).

Distribution in Argentina. Buenos Aires, Jujuy, La Pampa, Mendoza, and Rio Negro provinces (Lareschi et al. 2016).

Specimens Examined. None.

Additional Records. Jujuy: Pucará de Tilcara, ex N. lactens (Beaucournu and Castro 2003).

Remarks. In this study, this species neither was recorded nor specimens were reviewed. Others recorded hosts are: M. maenas (originally cited as M. australis) from Mendoza; Ctenomys fulvus Philippi 1860 (originally cited as Ctenomys robustus Philippi 1896) from Chile (Beaucournu et al. 2014; Bidau 2015). In NOA, the record corresponds to the Puna.

Tiamastus subtilis (Jordan and Rothschild 1923)

General distribution. Endemic to Argentina (Lareschi et al. 2016; Smit 1987).

Distribution in Argentina. Chubut and Tucuman provinces (Lareschi et al. 2016).

Specimens Examined. None.

Additional Records. Tucuman: Los Cardones, ex Ctenomys sp. (Beaucournu and Castro 2003).

Remarks. In this study, this species neither was recorded nor specimens were reviewed. Tiamastus subtilis is known from two localities, one in the south and the other in NOA, separated by $\sim 2500 \mathrm{~km}$. Other recorded host is $P$. xanthopygus from Chubut (Smit 1987). In the NOA, the record corresponds to the Yungas Forest. 
Family Ctenophthalmidae

Subfamily Ctenophthalminae

Tribe Agastopsyllini

Genus Agastopsylla Jordan and Rothschild 1923

Agastopsylla hirsutior Traub 1952

General distribution. Peru (Hopkins and Rothschild 1966), and recently it will be added to Argentina (López-Berrizbeitia et al. in press).

Distribution in Argentina. It is only known from one locality from Tucuman province (López-Berrizbeitia et al. in press).

Specimens Examined (2). Tucuman: Ciénaga Grande, San José de Chasquivil, 1 male (no number), 1 female (no number), ex A. spegazzinii (CML 7478).

Remarks. The type material is a female specimen deposited in the Field Museum of Natural History; but a new type was designed because the specimen was lost (López-Berrizbeitia et al. in press). The record corresponds to the Monte Desert of Mountains and Isolated Valleys.

\section{Agastopsylla nylota Traub 1952}

Agastopsylla nylota nylota Traub 1952

General distribution. Peru (Hopkins and Rothschild 1966), and recently it will be added to Argentina (López-Berrizbeitia et al. in press).

Distribution in Argentina. It is only known from one locality from Salta Province (López-Berrizbeitia et al. in press).

Specimens Examined (4). Salta: aproximadamente $15 \mathrm{~km}$ O Escoipe, sobre ruta provincial № 33, 3 males (no numbers), 1 female (no numbers), ex P. osilae (CML 8044).

Remarks. The type material, a male specimen, deposited in the Field Museum of Natural History, was lost, then a new type for the species was designed (López-Berrizbeitia et al. in press). One of the male specimens examined was misidentified as A. pearsoni in López-Berrizbetia et al. (2013a).

\section{Tribe Neotyphloceratini}

Genus Neotyphloceras Rothschild 1914

\section{Neotyphloceras chilensis Jordan 1936}

General distribution. Argentina, Chile, and Peru (Hopkins and Rothschild 1966; Lareschi et al. 2016).

Distribution in Argentina. Until now, this species was only known from the southern provinces of Argentina, Neuquén and Rio Negro (Lareschi et al. 2016); in this study three provinces from northwestern Argentina (Catamarca, Jujuy, and Salta) were added.

Specimens Examined (20). Catamarca: Paycuqui, 1 female (no number), ex Neotomys ebriosus Thomas 1894 (SNOMNH 30069), 1 female (no number), ex A. andina (CML 9217). Jujuy: $6.8 \mathrm{~km}$ al SE de Suripujio, sobre ruta provincial $N^{\circ} 5,1$ female (no number), ex P. xanthopygus (SNOMNH 30197); Sierra de Tilcara, El Hueco, 21 km SE de Tilcara, 1 male (no number), ex N. lactens (CML 9377). Salta: aproximadamente $15 \mathrm{~km} \mathrm{O}$ Escoipe, sobre ruta provincial № 33,1 female (no number), ex A. spegazzinii (CML 9240); Vega Cortadera, 4 males (no numbers), 4 females (no numbers), ex $A$. andina (CML 6874, SNOMNH 30219), 3 males (no numbers), 1 female (no numbers), ex E. puerulus (CML 9478, SNOMNH 34755). Chile: Valparaíso, 1 lectotype male (BMNH 1923-615), 1 paratype female (BMNH 1923-615), ex Thylamys elegans (Waterhouse 1839; unknown number; originally identified as Marmosa elegans), 1 allotype female (BMNH 1923-615), ex A. longipilis (unknown number).

Remarks. Traditionally, this species was considered as subspecies of N. crassispina, later Sanchez et al. (2012) redescribed it and considered it as valid species. In Argentina, this species was restricted to the south through few records (Beaucournu and Alcover 1990; Lareschi et al. 2016); therefore, this records, in three provinces of NOA, are relevant because extend the distribution of N. chilensis $\sim 2000$ kms northward. In this study, five new flea-host associations are recorded: $N$. chilensis with $N$. ebriosus, P. xanthopygus, $N$. lactens, A. andina, and E. puerulus.

\section{Neotyphloceras crassispina Rothschild 1914}

Neotyphloceras crassispina hemisus Jordan 1936

General distribution. Argentina, Bolivia, Chile, and Peru (Lareschi et al. 2016).

Distribution in Argentina. Catamarca, Jujuy, Mendoza, Neuquen, Rio Negro, Salta (Lareschi et al. 2016), and La Rioja provinces (López-Berrizbeitia et al. 2013b); in this study the Tucuman Province is added.

Specimens Examined (131). Catamarca: 17 km N Barranca Larga, 1 female (no number), ex P. xanthopygus (CML 8035), 1 female (no number), ex P. xanthopygus (SNOMNH 30201); $21 \mathrm{~km}$ SO El Desmonte, 1 male (no number), ex $M$. maenas (SNOMNH 30232); $3.4 \mathrm{~km}$ al $\mathrm{S}$ de la unión entre las rutas provinciales $\mathrm{N}^{\circ} 18$ y 9 , sobre ruta provincial $\mathrm{N}^{\circ} 18,1$ female (no number), ex P. osilae (CML 7229), 1 female (no number), ex N. lactens (SNOMNH 34512); Estancia Narváez, $5.5 \mathrm{~km} \mathrm{~N}$ La Chacritas en ruta provincial 1, 3 males (no numbers), 2 females (no numbers), ex A. alterus (SNOMNH 32997), 1 male (no number), ex C. musculinus (SNOMNH 35315), 2 females (no numbers), ex A. spegazzinii (CML 7198, 7202); Laguna Blanca, 1 male (no number), 1 female (no number), ex Eligmodontia bolsonensis Mares, Braun, Coyner and van den Bussche 2008 (CML 9436); Las Juntas, 3 males (no numbers), 2 females (no numbers), ex A. simulator (MIC 66, 104, 130), 2 females (no numbers), ex A. spegazzinii (MIC 87, 128), 1 male (no number), 2 females (no numbers), ex P. osilae (MIC 69); Otro Cerro, Rancho de los Crisho, 1 holotype male (BMNH 1923-615), ex A. edax (unknown number), 1 paratype female (BMNH 1923-615), ex R. auritus (unknown number; originally identified as $R$. caurinus), 1 topotype male (no number), unknown host; Pasto Ventura, 1 male (no number), ex $E$. bolsonensis (CML 7182); Paycuqui, 5 males (no numbers), 7 females (no numbers), ex A. andina (CML 6878, 6879, 9217, 9218; SNOMNH 30214), 3 males (no numbers), 2 females (no numbers), ex N. ebriosus (SNOMNH 30069, 33874), 1 female (no number), ex P. xanthopygus (SNOMNH 30205). Jujuy: 3 
km al E de Purmamarca por ruta nacional N 52, 4 females (no numbers), ex M. maenas (CML 12400); 9 km NO Bárcena, 1 female (no number), ex P. caprinus (SNOMNH 30081), 2 males (no numbers), 4 females (no numbers), ex $P$. caprinus (CML 6499), 4 males (no numbers), 8 females (no numbers), ex $P$. osilae (CML 6501, 8068, SNOMNH 30082), 5 males (no numbers), 14 females (no numbers), ex P. xanthopygus (SNOMNH 30191, 30193, 30194, 34028); Chilcayoc, 1 male (no number), ex P. xanthopygus (SNOMNH 30196); Sierra de Tilcara, Toro Arita, 12 km ESE de Maimará, 14 km ESE de Tilcara, 1 female (no number), ex A. jelskii (CML 8479). LA RIOJA: 4 km al O de Anillaco, Reserva Aguada de las Alturas, 2 males (CMLA 603, 604), ex P. xanthopygus (CML 9753); 5 km al S del cañón del Ocre, 1 male (no number), 2 females (no numbers), ex $P$. xanthopygus (CML 13020); 8 km al NE del Cañón del Ocre, 2 males (no numbers), 1 female (no number), ex $P$. osilae (CML 13011), 4 females (CMLA 606, 607, no numbers), ex P. xanthopygus (CML 13021); Quebrada de Santo Domingo 30 km al SO de Jagué, 1 female (no number), ex P. xanthopygus (CML 13047). Salta: Finca Barba Yaco, 8.5 km SE Ojo de Agua, 1 female (no number), ex P. xanthopygus (SNOMNH 30198). Tucuman: Lagunas de Huaca Huasi (Cumbres Calchaquíes), 1 male (no number), ex P. xanthopygus (CML 11746).

Additional Records. Jujuy: Cuesta de Lipán, 15 km O de Purmamarca, sobre ruta 52, ex P. xanthopygus; La Quiaca, 17 $\mathrm{km} O$ y $3 \mathrm{~km} \mathrm{~S}$, sobre ruta provincial No 5, ex $P$. xanthopygus (Lareschi et al. 2010).

Remarks. López-Berrizbeitia et al. (2015b) redescribed the subspecies amending the diagnosis. Hastriter et al. (2002) considered that $N$. c. hemisus could be synonymous of the nominal subspecies, but a comprehensive and detailed study is necessary in order to reach a conclusion. Five new flea-host associations were previously recorded with the following hosts: A. spegazzinii, O. brendae, A. andina (LópezBerrizbeitia et al. 2013b), and E. bolsonensis, N. lactens (LópezBerrizbeitia et al. 2015b); and in this study new six flea-host associations are reported with: $M$. maenas, $A$. alterus, $C$. musculinus, N. ebriosus, P. caprinus, and A. jelskii.

Subfamily Doratopsyllinae

Tribe Tritopsyllini

Genus Adoratopsylla Ewing 1925

Adoratopsylla (Tritopsylla) intermedia (Wagner 1901)

Adoratopsylla (Tritopsylla) intermedia intermedia (Wagner 1901)

General distribution. Argentina, Bolivia, Brazil, Ecuador, Paraguay, Peru, and Venezuela (Johnson 1957; Hopkins and Rothschild 1966; Lareschi et al. 2016).

Distribution in Argentina. Jujuy, Salta, Tucuman (Lareschi et al. 2016) and Misiones provinces (Urdapilleta et al. 2016).

Specimens Examined (67). Argentina. Jujuy: Casa Colorada, $\sim 2 \mathrm{~km}$ al $\mathrm{N}$ de Alfarcito, 1 male (no number) ex $P$. osilae (CML 8062). Salta: a $43.7 \mathrm{~km}$ del cruce de las rutas 50 y 18 , camino a Isla de Cañas, sobre ruta 18, 2 males (no numbers),
5 females (no numbers), ex Marmosa (Micoureus) constantiae Thomas 1904 (CML 7765), 6 males (no numbers), 6 females (no numbers), ex L. massoia (CML 7650, SNOMNH 32543), 7 females (no numbers), ex T. sponsorius (CML 6502, 7821). Tucuman: Dique San Ignacio, 1 male (no number), 2 females (no numbers), ex L. massoia (CML 2895), 25 females (no numbers), 4 males (no numbers), ex T. sponsorius (CML 7158, 7159, 7160, 1 released); Reserva La Florida, 7 km O Ibatín, sobre Río Pueblo Viejo, 1 male (no number), 2 females (no numbers), ex T. sponsorius (SNOMNH 29979); Río Grande, $5 \mathrm{~km}$ al S de El Siambón, 1 male (no number), 2 females (no numbers), ex $T$. cinderella (CML 7775). Paraguay: not specific locality, 1 male paralectotype (BMNH 1923-615), unknown host; Villarica, 1 female (BMNH 1964-287), ex Didelphis marsupialis Linnaeus 1758 (unknown number).

Additional records. Tucuman: Dique San Ignacio, ex $L$. massoia (Lareschi et al. 2016).

Remarks. During this study, this species was not recorded. Most hosts reported are marsupials, except in Jujuy where the species was recorded parasitizing a phyllotine rodent. Although L. massoia is not a small marsupial, is important to mention because $A$. (T.) i. intermedia exhibits a great preference for this host. The records from northwestern Argentina correspond to the Yungas Forests and Puna.

\section{Family Pulicidae \\ Subfamily Pulicinae \\ Tribe Pulicini \\ Genus Pulex Linnaeus 1758 \\ Pulex (Pulex) irritans Linnaeus 1758}

General distribution. Cosmopolitan (Hopkins and Rothschild 1953).

Distribution in Argentina. Buenos Aires, Catamarca, Chubut, Cordoba, Formosa, La Rioja, Mendoza, Neuquen, Rio Negro, Salta, San Luis, Santiago del Estero, and Tucuman provinces (Lareschi et al. 2016).

Specimens Examined (5). Argentina. Salta: 7.8 km NNE Pampa Grande, sobre ruta provincial № 6, 1 male (no number), 2 females (no numbers), ex Lycalopex gymnocercus Fischer 1814 (CML 7125). Hungary: Budapest, 1 neotype male (BMNH 916267), unknown host. France: Marsella, 1 female (BMNH 1923-615), ex Rodentia (unknown number).

Additional Records. La Rioja: not specific locality, ex Dolichotis patagonum Zimmermann 1780; entre Olta y Santa Rita de Catuna, ex Lepus sp. Salta: El Quebrachal, ex L. maximus. Santiago del Estero: not specific locality, unknown host. Tucuman: not specific locality, ex $D$. albiventris (originally identified as D. azarae; Hopkins and Rothschild 1953).

Remarks. The host mentioned by Hopkins and Rothschild (1953) as Lepus sp. probably corresponds to Lepus europaeus Pallas 1778 , because it is the only species of the genus of the order Lagomorpha in Argentina. The same authors not recorded the coordinates for the locality between Olta 
and Santa Rita de Catuna, La Rioja; in the present study, we indicate the coordinates for the two main localities cited by them (Olta: $-30^{\circ} 37^{\prime} 53.26^{\prime \prime} \mathrm{S},-66^{\circ} 15^{\prime} 48.87^{\prime \prime} \mathrm{W}$ and Santa Rita de Catuna: $\left.-30^{\circ} 57^{\prime} 03.87^{\prime \prime} \mathrm{S},-66^{\circ} 13^{\prime} 02.48^{\prime \prime} \mathrm{W}\right)$, but the exact locality of the record is still unknown. Although in NOA the species was only recorded on medium to large mammals, the records are included because its presence on small mammals is highly probable; also in other provinces of Argentina it was recorded on rodents such as G. griseoflavus, M. musculus, and Ctenomys sp. (Lareschi et al. 2016).

\section{Subfamily Xenopsyllinae \\ Tribe Xenopsyllini \\ Genus Xenopsylla Glinkiewiez 1907 \\ Xenopsylla cheopis (Rothschild 1903) \\ Xenopsylla cheopis cheopis (Rothschild 1903)}

General distribution. Cosmopolita (Hopkins and Rothschild 1953).

Distribution in Argentina. Buenos Aires and La Rioja provinces (Lareschi et al. 2016).

Specimens Examined (3). Nigeria: Olokemeji, 2 males (BMNH 379), 1 female (BMNH 379), ex Praomys daltoni Thomas, 1891 (unknown number; originally identified as Myomys daltoni).

Additional Records. La Rioja: not specific locality, ex $R$. norvegicus (originally cited as Epymis norvegicus), Rattus sp. (originally cited as Epimys sp.; Hopkins and Rothschild 1953).

Remarks. Xenopsylla cheopis cheopis is one of the most efficient vectors of Yersinia pestis (Lehmann and Neumann 1896), responsible for the bubonic plague (Boyer et al. 2014). The only known records of this species in the NOA corresponds to old records from La Rioja. The absence of new records of this species probably reflects the deficiency of sampling and studies in exotic rodents (López-Berrizbeitia et al. 2017); however, it is necessary to emphasize that the species was also recorded on a marsupial and a rodent of the family Cricetidae in Argentina (Lareschi et al. 2016).

Family Leptopsyllidae

Subfamily Leptopsyllinae

Tribe Leptosyllini

Genus Leptopsylla Jordan and Rothschild 1911

Leptopsylla (Leptopsylla) segnis (Schönherr 1811)

General distribution. Cosmopolitan (Hopkins and Rothschild 1971).

Distribution in Argentina. Buenos Aires, Jujuy, and Santa Fe provinces (Lareschi et al. 2016).

Specimens Examined. None.

Additional Records. Jujuy: not specific locality, unknown host (Lareschi et al. 2016).

Remarks. The species is originated in western Asia, but transported by man and is now found in almost the entire world. The main host is M. musculus, but it was also recorded on species of the genus Rattus (Hopkins and Rothschild 1971). The only record in NOA is doubtful; it was published in a bulletin of the First Argentine Entomo-epidemiological Conference (Bejarano et al. 1959) and except in Lareschi et al. (2016), it was not cited in the reviews of fleas from Argentina. The distribution in Argentina is disjunct, with records in Santa Fe and Buenos Aires provinces (central-eastern Argentina) and in Jujuy (NOA), with an absence of information in the intermediate provinces.

$$
\begin{aligned}
& \text { Family Ischnopsyllidae } \\
& \text { Subfamily Ischnopsyllinae } \\
& \text { Tribe Ischnopsyllini }
\end{aligned}
$$

Genus Myodopsylla Jordan and Rothschild 1911

Myodopsylla isidori (Weyenbergh 1881)

General distribution. Argentina, Chile, and Uruguay (Autino et al. 2004; Beaucournu et al. 2014; Lareschi et al. 2016).

Distribution in Argentina. Buenos Aires, Catamarca, Cordoba, Corrientes, Entre Rios, Jujuy, La Rioja, Neuquen, Rio Negro, San Luis, Salta, Santiago del Estero, and Tucuman provinces (Lareschi et al. 2016).

Specimens Examined (40). Catamarca: $22 \mathrm{~km}$ al SE de Villa de Escaba sobre ruta provincial № 9, 1 male (no number), ex Myotis dinellii Thomas 1902 [originally identified as Myotis levis (Geoffroy, 1824)] (released); Cuesta del Clavillo, 5 km al SO de La Banderita, 5 females (no numbers), ex M. dinellii (originally identified as M. levis; CML 3164, released). Jujuy: Río Las Capillas, $15 \mathrm{~km}$ al $\mathrm{N}$ de Las Capillas, por ruta provincial № 20, 1 female (no number), ex M. dinellii (CML 4317); Río Tiraxi, $1.5 \mathrm{~km}$ al E de Tiraxi, sobre ruta provincial $\mathrm{N}^{\circ} 29,2$ males (no numbers), 4 females (no numbers), ex Myotis keaysi J. A. Allen, 1914 (CML 6224). La Rioja: Anillaco $1.7 \mathrm{~m}$ al E del CRILAR, 1 female (CMLA 612), ex M. dinellii (released). Salta: $3 \mathrm{~km}$ al $\mathrm{N}$ de Potrerillos sobre ruta provincial $\mathrm{N}^{\circ} 6,1$ male (no number), 2 females (no numbers), ex M. dinellii (CML 8068, SNOMNH 27932); $7.8 \mathrm{~km}$ al NNE de Pampa Grande, sobre ruta provincial 6, sobre Río Cachi, 2 males (no numbers), 1 female (no number), ex M. dinellii (SNOMNH 27933); Río Los Sauces, 12 km NO del Jardín, ruta 6 km 110, 1 male (no number), 6 females (no numbers), ex M. dinellii (CML 11066). Tucuman: Arroyo El Saltón, Reserva Provincial Santa Ana, 1 female (no number), ex $M$. dinellii (originally identified as M. levis; CML 5451); Escaba de Abajo, Casa abandonada a $150 \mathrm{~m}$ de la Hostería Ekay Apu, 1 female (no number), ex $M$. albescens (Geoffroy, 1806; released); 2 males (no numbers), 6 females (no numbers), ex M. dinellii (released); Parque Provincial El Cochuna, camping, 1 female (no number), ex Myotis nigricans (Schinz, 1821; CML 4225). Not specific locality: 1 lectotype male (BMNH 1923-615), 1 allotype female (BMNH 1923-615), ex M. albescens (originally identified as Vespertilio isidori; unknown number). 
Additional Records. Catamarca: La Puerta, ex M. nigricans (Del Ponte 1977). Jujuy: Cuesta de Jaire, ex M. keaysi (Autino et al. 2016). La Rioja: not specific locality, ex Chiroptera (Hopkins and Rothschild 1956). Santiago del Estero: Sumampa, ex M. nigricans (Del Ponte 1977). Tucuman: Arroyo Aguas Chiquitas, Reserva Provincial Aguas Chiquitas, ex M. dinellii (originally cited as M. levis); Arroyo El Saltón, Reserva Provincial Santa Ana, ex M. albescens (Autino et al. 1999); Arroyo Mista, ex T. brasiliensis (Autino et al. 2009); Dique San Ignacio, ex M. albescens (Autino et al. 1999); Parque Provincial El Cochuna, camping, ex M. nigricans (Autino et al. 2000).

Remarks. Myodopsylla isidori exhibits a great preference for bats of the genus Myotis throughout its distribution (Autino et al. 2004; Beaucournu et al. 2014; Lareschi et al. 2016); although, in Argentina, it was also recorded on the genus Tadarida (Autino et al. 2009). In NOA, the records correspond to the Dry Chaco, Monte Desert of Mountains and Isolated Valleys, and Yungas Forests.

Myodopsylla wolffsohni (Rothschild 1903)

Myodopsylla wolffsohni wolffsohni (Rothschild 1903)

General distribution. Argentina, Brazil, Paraguay, and Uruguay (Linardi and Guimarães 2000; Claps and Autino 2012). Beaucournu et al. (2014) reported that the subspecies was misidentified in Chile and that specimen corresponds to M. isidori. However, Lareschi et al. (2016) sustained the error and mentioned it wrongly for Chile and Mexico (SalcedaSánchez and Hastriter 2006; Acosta-Gutiérrez 2014).

Distribution in Argentina. Corrientes, Entre Rios, Salta, and Tucuman provinces (Lareschi et al. 2016).

Specimens Examined (2). Paraguay: Tacuaral, 1 holotype male (BMNH 1923-615), 1 female allotype (BMNH 1923-615), ex M. albescens (unknown number). Uruguay: Paso Pache, Río Santa Lucia, Puente Viejo, 1 male (no number) ex M. albescens (EMG 1183).

Additional Records. Salta: La Estrella, ex M. nigricans (Autino et al. 2016); Río El Naranjo, 14 km al O de ruta provincial № 5, sobre camino de acceso a Parque Nacional El Rey, ex M. albescens (Claps and Autino 2012). Tucuman: not specific locality, ex E. perotis (Schinz 1821).

Remarks. During this study, the subspecies was not recorded. The records correspond to the Dry Chaco and Yungas Forests.

\section{Tribe Sternopsyllini}

Genus Hormopsylla Jordan and Rothschild 1921

Hormopsylla fosteri (Rothschild 1903)

General distribution. Argentina, Brazil, Paraguay, and Venezuela (Hastriter and Guerrero 1998).

Distribution in Argentina. Cordoba and Tucuman provinces (Lareschi et al. 2016).

Specimens Examined. None.

Additional Records. Tucuman: Capital, ex E. perotis (Hopkins and Rothschild 1956; Del Ponte 1977).
Remarks. In this study, this species neither was recorded nor specimens were reviewed. Although the species was recorded mainly on insectivorous bats of the family Molossidae, there is a record on a hematophagous bat, Desmodus rotundus (Familia Phyllostomidae) from Brazil (Linardi and Guimarães 2000).

\section{Genus Sternopsylla Jordan and Rothschild 1921 \\ Sternopsylla distincta (Rothschild 1903) \\ Sternopsylla distincta speciosa (Rothschild 1903)}

General distribution. Argentina, Colombia, Panama, Paraguay, Peru, and Venezuela (Del Ponte 1977; Lareschi et al. 2016).

Distribution in Argentina. Buenos Aires, Catamarca, Jujuy, Mendoza, Salta, and Tucuman provinces (Lareschi et al. 2016). In this study, the subspecies is added in the La Rioja province.

Specimens Examined (6). Argentina. Buenos Aires: Estancia San José, sobre Río Negro (Partido Patagones), 1 female (no number), ex T. brasiliensis (released). Jujuy: San Salvador de Jujuy, 1 male (no number), 2 females (no numbers), ex $T$. brasiliensis (unknown number). La Rioja: Ulapes, $1 \mathrm{~km}$ al $\mathrm{O}$ de la plaza principal de Ulapes, 1 female (no number), ex $T$. brasiliensis (CML 12871). Tucuman. Dique San Ignacio, 1 male (no number), ex M. albescens (CML 5614). Panama: Chiriquí, Bambito-Cerro Punta, 1 female (BMNH 10087), ex guano of Chiroptera.

Additional Records. Catamarca: El Rodeo, ex T. brasiliensis (Del Ponte 1977). Salta: Rosario de La Frontera, ex T. brasiliensis (Autino et al. 1999). Tucuman: Dique Escaba; Dique San Ignacio; San Miguel de Tucuman, ex T. brasiliensis (Del Ponte 1977).

Remarks. Sternopsylla distincta exhibits a great preference for bats of the family Molossidae (Johnson 1957; Tipton and Machado-Allison 1972), although it also was recorded on bats of the genus Myotis (family Vespertilionidae), in Argentina and Panama (Del Ponte 1977; Lareschi et al. 2016). Del Ponte (1977) and Beaucournu and Castro (2003) questioned the validity of the subspecies and suggested that it could be a synonym of the nominal. The examined specimens show all characters diagnostic for the subspecies; although, it is necessary to carry out morphological studies of the males and females of both subespecies in order to verify the existence of variation between them. In NOA the records correspond to the Dry Chaco and Yungas Forests.

\section{Family Ceratophyllidae}

Subfamily Ceratophyllinae

Genus Nosopsyllus Jordan 1933

Nosopsyllus (Nosopsyllus) fasciatus (Bosc 1800)

General distribution. Cosmopolitan (Lewis 1990).

Distribution in Argentina. Buenos Aires, Cordoba, Jujuy, Neuquen, Rio Negro, Santa Fe, Tierra del Fuego, Antarctica and Southern Atlantic Islands, and Islas Malvinas (Lareschi etal. 2016). 
Specimens Examined (2). Hungary: Budapest, 1 male (BMNH 1923-615), ex $R$. norvegicus (originally identified as Mus decumanus; unknown number). France: Bure, 1 female (BMNH 1923-615), nest of Rodentia.

Additional Records. Jujuy: not specific locality, ex R. norvegicus and R. rattus (Bejarano et al. 1959; Lareschi et al. 2016).

Remarks. In Argentina, others hosts for this species are: Abrothrix longipilis, Akodon olivaceus, and $O$. longicaudatus (Lareschi et al. 2016). The only record in NOA was published in a bulletin of the First Argentine Entomo-epidemiological Conference (Bejarano et al. 1959), except in Lareschi et al. 2016 it not was cited in the reviews of fleas from Argentina.

Index of similarity $\left(\mathrm{I}_{\mathrm{j}}\right)$

The index of similarity among ecoregions was calculated based on 49 species and five subspecies, including four new species in the process of description [Ectinorus (E.) sp. n. 1, Ectinorus (E.) sp. n. 2, Ectinorus (E.) sp. n. 3 and Polygenis (P.) sp. n.], and three species and one subspecies were excluded because no specific localities were available.

The coefficient of Jaccard discriminated two main clusters, one constituted by High Andes and Puna and another by Yungas Forests, Dry Chaco, and Monte Desert of Mountains and Isolated Valleys (Figure 2). The highest similarity value was recorded between Yungas Forests and Dry Chaco $\left(I_{i}=0.29\right)$, and this cluster is grouped with the Monte Desert of Mountains and Isolated Valleys. The greatest differentiation was recorded between High Andes and Puna (Figure 2, Table 2).

\section{Discussion}

A total of 971 flea specimens were studied, of which 851 correspond to species from NOA and 120 are specimens from other localities used for comparative purposes. The specimens examined included 35 holotypes, 21 allotypes, 43 paratypes, 22 lectotypes, 12 paralectotypes, four neotypes, and six topotypes. Until now eight families, 19 genera, 40 species and seven subspecies of Siphonaptera, parasites of small mammals (Didelphimorphia, Chiroptera, and Rodentia), were known from NOA. The family Pygiopsyllidae, the genus Agastopsylla and three species and one subspecies (Agastopsylla hirsutior, Agastopsylla nylota nylota, and Plocopsylla (P.) inti) are new records for Argentina; five species and one subspecies: Neotyphloceras Chilensis, Delostichus talis, Ectinorus hapalus, Polygenis (P.) pradoi, and Polygenis bohlsi bohlsi are new for NOA. In this study we have recorded nine species that are new to science, five of which were recently published (Ctenidiosomus austrinus, Cleopsylla barquezi, Plocopsylla (P.) chicoanaensis, Plocopsylla (P.) hastriteri, and Tetrapsyllus (T.) spegazzinii; Lopez-Berrizbeitia et al. 2016, $\underline{2018}, \underline{2019}$ ), and four more which are in process of description, belonging to the genus Polygenis and Ectinorus (Rhopalopsyllidae).

Six species are considered as probable for the study area, due to records obtained in other regions of the country, but cited on small mammals whose distributions
SIMILITARY

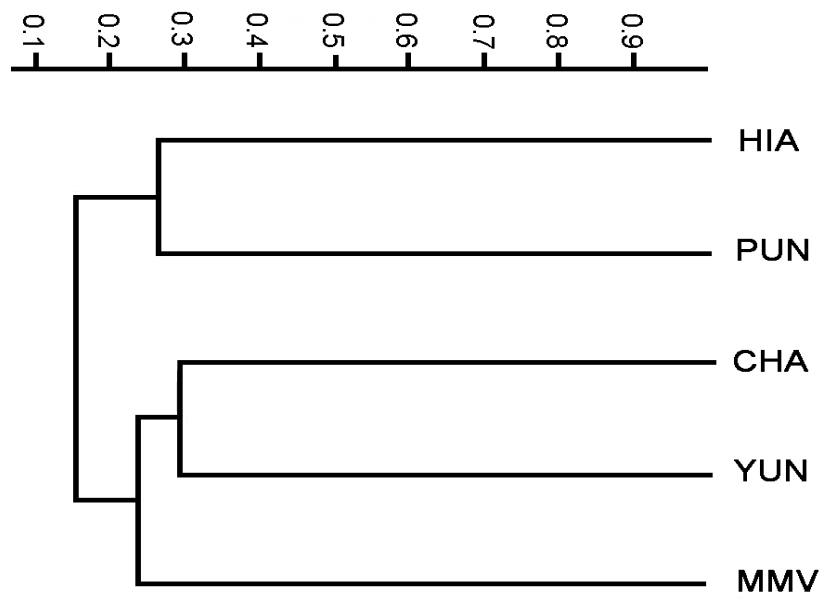

Figure 2. Consensus phenogram of ecoregions in northwestern Argentina at species and subspecies levels. Acronyms: $\mathrm{HIA}=$ High Andes, $\mathrm{CHA}=$ Dry Chaco, $\mathrm{MMV}=$ Monte Desert of Mountains and Isolated Valleys, $\mathrm{PUN}=\mathrm{Puna}, \mathrm{YUN}=$ Yungas.

include the NOA [Hectopsylla (Hectopsylla) cypha, Hectopsylla (Hectopsylla) stomis, and Pulex irritans], or referenced for the area but without punctual records [Hectopsylla (Hectopsylla) psittaci, Leptopsylla (Leptopsylla) segnis, and Nosopsyllus fasciatus]. Additionally species and subspecies are added for almost all provinces of the NOA, four species and one subspecies are added in Tucuman: $H$. $(H$.) gracilis, $H$. $(H$.) gemina, N. c. hemisus, and T. (P.) bleptus; five in Catamarca: $H$. (H.) gracilis, D. talis, $P$. (N.) pradoi, $P$. (N.) puelche, and $P$. (P.) byturus); eight species and one subspecies in La Rioja: $H$. (H.) gracilis, N. c. hemisus, D. talis, $T$. $(P$.) bleptus, $P$. $(P$.$) acodontis, P$. (P.) byturus, T. palpalis, and C. minerva; five species and one subspecies in Salta: H. (H.) gracilis, T. (P.) bleptus, $P$. (N.) pradoi, $P$. (N.) puelche, and P. (P.) r. beebei); and one species in Santiago del Estero: $P$. $(P$.$) acodontis. The record of H$. $(H$.$) gemina$ obtained in Tucuman allows us to confirm its presence in the study area through a punctual locality. It is important to mention that some species are still known only by historical records, such as $E$. (E.) budini only collected in the type locality, Otro Cerro (Catamarca), 70 years ago; for this reason, it is important to increase the sampling efforts in the areas where these species were long ago collected.

On the other hand, most of the ecoregions from NOA suffers an accelerated degradation process such as the Chaco (Torrella et al. 2007, 2011) and Yungas Forests (Brown et al. 2001). The natural vegetation is changing and their replacement by crop areas affect on the small mammal hosts in this type of habitats (Ewers and Didham 2006; Peters et al. 2006), with the consequent reduction of its population, probably a reason why during the fieldwork some species were not collected even with a great trapping effort. As an example, for $E$. (E.) disjugis, the only known locality (El Chaguaral) for the presence of this species in Argentina, belongs to the Dry Chaco in Jujuy Province, a highly disturbed and fragmented area with almost no traces of well-preserved natural vegetation which implies reduction or lost of the small mammals 
communities in the area (Torres and Jayat 2010). Other examples are H. stomis, E. galeanus, and E. rimatus, collected in localities in Santiago del Estero, a province where the Dry Chaco is almost restricted to the Copo National Park or some small mountainous areas in the province (Torrella and Adámoli 2005; Díaz and Barquez 2007).

The distribution and amplitude of the geographical range of a flea species result from the interaction between the responses to the geographical range of its hosts and the environmental conditions of its microhabitats (Krasnov 2008). In this study the flea species were recorded in five of the six ecoregions represented in the NOA: Dry Chaco, Monte Desert of Mountains and Isolated Valleys, High Andes, Puna, and Yungas Forests (Table 1). The Yungas Forests have the greatest number of species of fleas, followed by the Monte Desert of Mountains and Isolated Valleys, Dry Chaco, High Andes, and Puna. The higher diversity in the Yungas Forests is a reflection of an area with the greatest diversity in the Neotropical region (Mittermeier et al. 1999), including mammals (Barquez et al. 2006; Gamboa-Alurralde et al. 2015) with the sigomodontine rodents and bats (Díaz and Barquez 2007; Barquez and Díaz 2009; Gamboa Alurralde et al. 2016; Gamboa Alurralde 2017). These small mammals were the main hosts for the families Rhopalopsyllidae and Ischnopsyllidae, two of the most diverse in the Yungas Forests. The family Tungidae, only represented by the genus Hectopsylla, was mainly distributed in the Yungas and the Dry Chaco, with records agreeing with previous citations that show this family with a distribution mainly neotropical (Sanchez 2012, Lareschi et al. 2016). Ctenidiosomus austrinus, the only species of the family Pygiopsyllidae, was restricted to the Monte Desert of Mountains and Isolated Valleys, following the distribution of their host, $P$. osilae, found along the Oriental Altiplano and the Andean slopes (Jayat and Pacheco 2006; Steppan and Ramirez 2015). Most species of the family Stephanocircidae were recorded in the Puna, representing mainly an Andean distribution; these spe- cies were also found in the Patagonia parasitizing rodents of the same genera as those recorded in our study area, Abrothrix, Akodon and Calomys (Sanchez 2012); this situation would support the idea of a close relationship between Puna and Patagonian Steppes proposed by Cabrera (1976) and Burkart et al. (1999). Craneopsylla minerva was the only species found in all analyzed ecoregions, which would be related to the large number of hosts parasitized by this species because, in general, the specialist fleas have restricted geographical ranges whereas the generalist fleas have wide ranges allowing them not only to exploit more host species, but also to hosts species which are not necessary phylogenetically related (Krasnov et al. 2005).

The analysis of degree of affinity among ecoregions showed a great faunistic congruence between Yungas Forests and Dry Chaco, sharing 11 species of the families Tungidae, Stephanocircidae, Rhopalopsyllidae, and Ischnopsyllidae. This result was expected because studies developed on other group of animals, for example mammals, were similar (Díaz and Barquez 2007). The ecoregions with the highest differentiation were the High Andes and the Puna ecoregions, being the ecoregions that share less species compared with the other ecoregions; these areas were also the least sampled and containing the lowest richness and abundance of small mammal species, specially marsupials and bats (Figure 2, Table 2).

In the Neotropical region the fleas parasitize mainly on small mammals, as sigmodontine and caviomorph rodents, as well as on marsupials of the orders Didelphimorphia and Paucituberculata (Krasnov 2008). A total of 82 new flea-host associations were recorded; 81 associations have sigomodontine rodents (Family Cricetidae) as hosts, and one association was found with a marsupial (Order Didelphimorphia; Table 1). According to Krasnov (2008), the high diversity of fleas associated to rodents suggests, from an evolutionary perspective, that diversification of the fleas was associated to the great diversification of rodents.

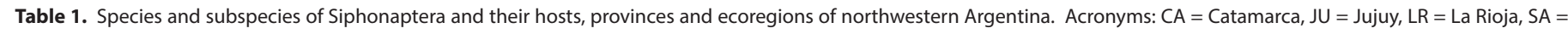
Salta, SE=Santiago del Estero, TU = Tucuman. HIA = High Andes, $\mathrm{CHA}=$ Dry Chaco, MMV = Monte Desert of Mountains and Isolated Valleys, PUN = Puna, and YUN = Yungas.

\begin{tabular}{|c|c|c|c|}
\hline Siphonaptera & Hosts & Provinces & Ecoregions \\
\hline Hectopsylla (H.) cypha & Lagostomus sp. & $\mathrm{LR}, \mathrm{TU}$ & MMV \\
\hline Hectopsylla (H.) gemina & P. osilae, M. jayat & $\mathrm{SE}, \mathrm{TU}$ & $\mathrm{CHA}, \mathrm{YUN}$ \\
\hline Hectopsylla $(H$.$) gracilis$ & $\begin{array}{l}\text { A. andina, A. albiventer, A. caenosus, A. spegazzinii, A. olrogi, E. hirtipes, E. puerulus, E. } \\
\text { moreni, E. typus, G. chacoensis }\end{array}$ & CA, JU, LR, SA, TU & HIA, MMV, PUN, YUN \\
\hline Hectopsylla (H.) psittaci & E. perotis & TU & - \\
\hline Hectopsylla (H.) pulex & E. perotis, T. brasiliensis & CA, JU, TU, SA & CHA, YUN \\
\hline Hectopsylla (H.) stomis & L. maximus & $\mathrm{SE}, \mathrm{SA}$ & $\mathrm{CHA}$ \\
\hline Ctenidiosomus austrinus & P. osilae & SA & MMV \\
\hline Cleopsylla barquezi & A. spegazzinii, P. osilae & $\mathrm{CA}, \mathrm{SA}, \mathrm{TU}$ & MMV, YUN \\
\hline Craneopsylla minerva & $\begin{array}{l}\text { C. auritus, L. massoia, T. sponsorius, A. andina, A. illutea, A. alterus, A. budini, A. } \\
\text { caenosus, A. cf. fumeus, A. glaucinus, A. lutescens, A. puer, A. simulator, A. spegazzinii, } \\
\text { A. tartareus, A. toba, A. tucumanensis, C. boliviae, C. callosus, C. venustus, E. legatus, G. } \\
\text { leucoblephara, G. chacoensis, G. domorum, G. griseoflavus, H. chacarius, M. jayat, M. } \\
\text { maenas, O. brendae, O. flavescens, O. paramensis, P. caprinus, P. osilae, P. xanthopygus, } \\
\text { R. rattus, Rattus sp., T. wolffsohni, T. primus. }\end{array}$ & CA, JU, LR, SA, SE, TU & HIA, CHA, MMV, PUN, YUN \\
\hline Nonnapsylla rothschildi & E. puerulus, G. comes, O. gliroides, P. xanthopygus & JU & PUN \\
\hline
\end{tabular}




\begin{tabular}{|c|c|c|c|}
\hline Plocopsylla (P.) chicoanaensis & A. caenosus, A. spegazzinii, P. osilae, Oligoryzomys sp. & CA, SA & MMV, PUN, YUN \\
\hline Plocopsylla (P.) hastriteri & P. osilae & LR & MMV \\
\hline Plocopsylla (P.) inti & A. andina & CA & PUN \\
\hline Tiarapsylla argentina & Ctenomys sp. & $\mathrm{JU}, \mathrm{TU}$ & PUN, YUN \\
\hline Delostichus talis & M. maenas & $C A, L R$ & MMV, PUN \\
\hline Ectinorus (E.) budini & A. edax & CA & MMV \\
\hline Ectinorus $(E$.$) disjugis$ & C. juris & JU & $\mathrm{CHA}$ \\
\hline Ectinorus (E.) hapalus & G. chacoensis & LR & MMV \\
\hline Ectinorus (E.) nomisis & O. gliroides & JU & PUN \\
\hline Ectinorus (E.) pilosus & C. knighti & CA & MMV \\
\hline $\begin{array}{l}\text { Ectinorus (E.) } \\
\text { sp. n. } 1\end{array}$ & A. spegazzinii, P. osilae & $C A, S A$ & MMV, YUN \\
\hline $\begin{array}{l}\text { Ectinorus (E.) } \\
\text { sp. n. } 2\end{array}$ & A. spegazzinii & CA & YUN \\
\hline $\begin{array}{l}\text { Ectinorus (E.) } \\
\text { sp. n. } 3\end{array}$ & A. andina, P. xanthopygus & TU & HIA \\
\hline Ectinorus $(P$.$) galeanus$ & G. chacoensis, M. jayat, L. maximus & SE & $\mathrm{CHA}$ \\
\hline Tetrapsyllus (P.) bleptus & A. andina, A. albiventer, A. simulator, A. spegazzinii & $\mathrm{JU}, \mathrm{CA}, \mathrm{LR}, \mathrm{SA}, \mathrm{TU}$ & HIA, CHA, MMV, PUN, YUN \\
\hline $\begin{array}{l}\text { Tetrapsyllus (T.) } \\
\text { spegazzinii }\end{array}$ & A. spegazzinii, A. simulator & SA & MMV, YUN \\
\hline Polygenis (N.) pradoi & A. spegazzinii & CA, SA & MMV, YUN \\
\hline Polygenis (N.) puelche & A. lutescens, A. simulator, A. spegazzinii, O. brendae & CA, SA, TU & YUN \\
\hline Polygenis acodontis & $\begin{array}{l}\text { T. sponsorius A. alterus, A. budini, A. caenosus, A. cf. fumeus, A. dolores, A. glaucinus, A. } \\
\text { lutescens, A, puer, A. simulator, A. spegazzinii, C. boliviae, C. venustus, C. juris, M. australis, } \\
\text { N. lactens, O. brendae, Oligoryzomys sp., O. paramensis, P. osilae, P. xanthopygus }\end{array}$ & $\mathrm{CA}, \mathrm{JU}, \mathrm{LR}, \mathrm{SA}, \mathrm{SE}, \mathrm{TU}$ & $\mathrm{CHA}, \mathrm{MMV}, \mathrm{YUN}$ \\
\hline Polygenis (P.) bolhsi bolhsi & G. chacoensis & LR & $\mathrm{CHA}$ \\
\hline Polygenis (P.) byturus & $\begin{array}{l}\text { A. alterus, A. dolores, C. callosus, C. musculinus, C. venustus, C. juris, G. leucoblephara, } \\
\text { G. chacoensis, G. griseoflavus, H. chacarius, L. maximus, M. australis, P. xanthopygus, } \\
\text { R. rattus }\end{array}$ & $\mathrm{CA}, J U, \mathrm{LR}, \mathrm{SA}, \mathrm{SE}$ & CHA, YUN \\
\hline Polygenis (P.) platensis & A. glaucinus, G. leucoblephara, G. chacoensis, G. griseoflavus, P. osilae, P. xanthopygus & $J U, L R, S A$ & CHA, MMV, YUN \\
\hline Polygenis (P.)rimatus & D. albiventris, C. aperea, M. australis & $\mathrm{LR}, \mathrm{SA}$ & $\mathrm{CHA}$ \\
\hline Polygenis $(P$.$) roberti bebeei$ & E. legatus & JU, SA & YUN \\
\hline Polygenis (P.) tripus & A. tartareus, G. leucoblephara & SA & YUN \\
\hline Polygenis (P.) sp. $\mathrm{n}$. & A. spegazzinii & SA & MMV \\
\hline Tiamastus cavicola & C. juris, G. leucoblephara, M. maenas & $C A, J U, S A$ & CHA, PUN, YUN \\
\hline Tiamastus helicis & C. latro & TU & YUN \\
\hline Tiamastus palpalis & Ctenomys sp., C. juris, E. moreni & CA, JU, LR, SE & $\mathrm{CHA}, \mathrm{MMV}$ \\
\hline Tiamastus plesius & N. lactens & JU & PUN \\
\hline Tiamastus subtilis & Ctenomys sp. & TU & YUN \\
\hline Agastopsylla hirsutior & A. spegazznii & TU & YUN \\
\hline Agastopsylla nylota nylota & P. osilae & SA & MMV \\
\hline Neotyphloceras chilensis & A. andina, A. spegazzinii, E. puerulus, N. lactens, N. ebriosus, P. xanthopygus & $C A, J U, S A$ & MMV, PUN \\
\hline Neotyphloceras crassispina hemisus & $\begin{array}{l}\text { A. andina, A. jelskii, A. albiventer, A. alterus, A. simulator, A. spegazzinii, A. edax, C. } \\
\text { musculinus, C. lepidus, E. bolsonensis, E. hirtipes, E. puerulus, G. chacoensis, M. australis, } \\
\text { M. maenas, N. lactens, N. ebriosus, O. brendae, P. alisosiensis, P. caprinus, P. osilae, P. } \\
\text { xanthopygus, Phyllotis sp., R. auritus }\end{array}$ & CA, JU, LR SA, TU & HIA, MMV, PUN, YUN \\
\hline Adoratopsylla intermedia intermedia & L. massoia, M. constantiae, T. cinderella, T. sponsorius, P. osilae. & JU, SA, TU & PUN, YUN \\
\hline Pulex irritans & D. albiventris, D. patagonum, L. maximus & LR, SA, SE, TU & $\mathrm{CHA}$ \\
\hline Xenopsylla cheopis cheopis & R. norvegicus, Rattus sp. & LR & - \\
\hline Leptopsylla (L.) segnis & Rodentia & JU & - \\
\hline Hormopsylla fosteri & E. perotis & TU & YUN \\
\hline Myodopsylla isidori & M. albescens, M. dinellii, M. keaysi, M. nigricans, T. brasiliensis & $C A, J A, L R, S A, S E, T U$ & CHA, MMV, YUN \\
\hline Myodopsylla wolffsohni wolffsohni & E. perotis, M. albescens, M. nigricans & SA, TU & CHA, YUN \\
\hline Sternopsylla distincta speciosa & M. albescens, T. brasiliensis & $C A, J U, L R, S A, T U$ & CHA, YUN \\
\hline Nosopsyllus fasciatus & - & JU & - \\
\hline
\end{tabular}


Table 2. Results of the Jaccard index among the ecoregions of northwestern Argentina. Acronyms: $\mathrm{HIA}=$ High Andes, $\mathrm{CHA}=$ Dry Chaco, $\mathrm{MMV}=$ Monte Desert of Mountains and Isolated Valleys, $\mathrm{PUN}=\mathrm{Puna}$, and $\mathrm{YUN}=$ Yungas

\begin{tabular}{llllll}
\hline & PUN & MMV & CHA & YUN & HIA \\
\hline PUN & 1 & 0.20 & 0.11 & 0.24 & 0.27 \\
MMV & 0.20 & 1 & 0.18 & 0.29 & 0.13 \\
CHA & 0.11 & 0.18 & 1 & 0.29 & 0.10 \\
YUN & 0.24 & 0.29 & 0.29 & 1 & 0.14 \\
HIA & 0.27 & 0.13 & 0.10 & 0.14 & 1 \\
\hline
\end{tabular}

Finally, the results reported here mainly contribute to the knowledge and clarification of the systematics of the species of the order Siphonaptera parasitizing small mammals in NOA, providing new information not only for the region but also for Argentina and for science.

\section{Acknowledgements}

We want to thank to the members of the PIDBA (Programa de Investigaciones de Biodiversidad Argentina) for their help during the field and lab work. For the loan specimens we thank to profesor J.-C. Beaucournu (Rennes, France) and Dr. M. Hastriter (Provo, U.S.A). M. F. Lopez Berrizbeitia thanks to Erica McAlister, curator of the British Museum (Natural History), for her help during the visit to the collection. The field trips were supported by CONICET (Consejo Nacional de Investigaciones Científicas y Técnicas), Argentina through the fellowship to Fernanda Lopez Berrizbeita and the project PIP 4963, and the projects granted by the CIUNT: $26 / Z 103$ and 26/G207. Finally, we thank to Ruben Barquez for his help with the manuscript.

\section{Literature cited}

Acosta-Gutiérrez, R. 2014. Biodiversidad de Siphonaptera en México. Revista Mexicana de Biodiversidad 85:345-352.

Autino, A. G., AND M. LaresCHI. 1998. Siphonaptera. Pp. 279-290 in: Biodiversidad de Artrópodos Argentinos (Morrone J. J. and S. Coscarón, Dir.). Ediciones Sur, La Plata, Argentina.

Autino, A. G., G. L. Claps and F. Ortiz. 2005. Primera cita de Sternopsylla distinctaspeciosa (Siphonaptera: Ischnopsyllidae) para la provincia de Jujuy, Argentina. Revista de la Sociedad Entomológica Argentina 64:34-36.

Autino, A. G., G. L. Claps, and E. M. González. 2004. Nuevos registros de insectos (Diptera y Siphonaptera) ectoparásitos de murciélagos (Vespertilionidae) del norte de Uruguay. Mastozoología Neotropical 11:81-83.

Autino, A. G., G. L. Claps, and R. M. Barquez. 1999. Insectos ectoparásitos de murciélagos de las yungas de la Argentina. Acta Zoológica Mexicana 78:119-169.

Autino, A. G., G. L. Claps, and R. M. Barquez. 2000. Nuevos registros de Diptera y Siphonaptera en la Argentina. Boletín de Entomología Venezolana 15:109-112.

Autino, A. G., F. Ortiz, G. L. Claps, and J. C. Bracamonte. 2016. New host and locality records for chiropteran ectoparasites from Jujuy and Salta provinces, Argentina. Check List 12:1895.

Autino, A. G., G. L. Claps, M. Sánchez, and R. M. Barquez. 2009. New records of bat ectoparasites (Diptera, Hemiptera and Siphonaptera) from northern Argentina. Neotropical Entomology 38:165-177. https://doi.org/10.1590/s1519$\underline{566 \times 2009000200002}$

BAKER, R. J., AND S. L. WILLIAMS. 1972. A live trap for pocket gophers. Journal of Wildlife Management 36:1320-1322.

Barquez, R. M., and M. M. Diaz. 2009. Los Murciélagos de Argentina-Clave de Identificación. Publicación Especial $N^{\circ}$ 1. PCMA (Programa de Conservación de los Murciélagos de Argentina), Editorial Magna, Tucumán, Argentina.

Barquez, R. M., M. M. Díaz, And R. A. OJeda. 2006. Mamíferos de Argentina. Sistemática y distribución. Sociedad Argentina para el Estudio de los Mamíferos (SAREM), Mendoza, Argentina.

Barquez, R. M., M. S. Sánchez, and J. C. Bracamonte. 2009. Nueva especie de Eptesicus (Chiroptera, Vespertilionidae) para Argentina. Mastozoología Neotropical 16:199-203.

Barquez, R. M., M. S. Sánchez, AND M. L. Sandoval. 2011. Nuevos registros de murciélagos (Chiroptera) en el norte de Argentina. Mastozoología Neotropical 18:10-24. http://ref. scielo.org $/ 5 \mathrm{mrcwb}$

Barquez, R. M., D. Miotti, F. Idoeta, and M. M. Díaz. 2017. Two new species of Myotis (Chiroptera: Vespertilionidae from Argentina. Papéis Avulsos de Zoología 57:287-294.

Beaucournu, J. C., and D. Castro. 2002. Ectinorus pilosus sp. $\mathrm{n}$. (Siphonaptera: Rhopalopsyllidae), puce nouvelle d'Argentine. Bulletin de la Société entomologique de France 107:367-369. Beaucournu, J. C., and D. Castro. 2003. Contribution á un Inventaire des Puces d'Argentina. Beiträge zur Entomologie 53:449-479.

Beaucournu, J. C., And J. A. Alcover. 1990. Puces récoltées dans la Province de Neuquén (Argentine); description de 4 nouveau taxa (Insecta, Siphonaptera). Annales de Parasitologie humaine et comparée 64:489-505.

Beaucournu, J. C., and J. C. Torres-Mura. 1987. Un nouveau Delostichus (Siphonaptera, Rhopalopsyllidae) d'Argentine. Bulletin de la Société Française de Parasitologie 5:257-260.

Beaucournu, J. C., and M. H. Gallardo. 1988. Puces nouvelles d' Argentine (Insecta, Siphonaptera). Revue Suisse de Zoologie 95:99-112.

Beaucournu, J. C., and M. H. Gallardo. 2005. Deux puces nouvelles (Siphonaptera: Rhopalopsyllidae: Parapsyllinae) $d^{\prime}$ Argentine, parasites $d^{\prime}$ Abr. uspallata Braun et Mares, 2002 (Rod.: Abrocomidae). Parasite 12:39-43. http://dx.doi. org/10.1051/parasite/2005121039

Beaucournu, J. C., L. Moreno, and D. González-Acuña. 2014. Fleas (Insecta-Siphonaptera) of Chile: a review. Zootaxa 2:151-203. Beaucournu, J. C., M. H. Gallardo, and K. Ménier. 2004. Deux puces nouvelles du Chili et d' Argentine (Insecta-Siphonaptera: Stephanocircidae et Rhopalopsyllidae) et érection d'un sousgenre chez Plocopsylla Jordan, 1931. Parasite 11:249-252. http://dx.doi.org/10.1051/parasite/2004113249

Beaucournu, J. C., S. Belaz, S. Muñoz-Leal, and D. GonzálezAcuÑ. 2013. A new flea, Ectinorus (Ectinorus) insignis sp. n. (Siphonaptera, Rhopalopsyllidae, Parapsyllinae), with notes on the subgenus Ectinorus in Chile and comments on unciform sclerotization in the Superfamily Malacopsylloidea. Parasite, 20:1-12. http://dx.doi.org/10.1051/parasite/2013033

Bejarano, J. F. R., E. del Ponte, and R. N. Orfila. 1959. Primeras Jornadas Entomoepidemiológicas Argentinas, segunda 
parte. Buenos Aires, Argentina, 581-586.

BIDAU, C. J. 2015. Family Ctenomyidae. Pp: 818-876 in: Mammals of South America, Volume 2 - Rodents (Patton, J. L., U. F. J. Pardiñas, and G. D'Elía, Eds.). The University of Chicago Press. Chicago, U.S.A.

Bolsi, A. S. C, C. Caponio, A. Batista, M. Madariaga, A. Nieva, R. Pucci, AND A. Rivas. 1997a. Subproyecto III. Estructuras productivas I. Universidad Nacional de Tucumán. Facultad de Filosofía y Letras. Instituto de Estudios Geográficos. Instituto de Estudios Geográficos. San Miguel de Tucumán, Argentina.

Bolsi, A. S. C, C. Caponio, A. Batista, M. Madariaga, A. Nieva, R. Puccl, AND A. Rivas. 1997b. Subproyecto II. Universidad Nacional de Tucumán. Facultad de Filosofía y Letras. Instituto de Estudios Geográficos. Instituto de Estudios Geográficos. San Miguel de Tucumán, Argentina.

Boyer, S., A. Miarinjara, And N. Elissa. 2014. Xenopsylla cheopis (Siphonaptera: Pulicidae) susceptibility to deltamethrin in Madagascar. PLoS ONE 9:e111998. https://doi.org/10.1371/ journal.pone.0111998

Braun, J. K., AND M. M. Díaz. 1999. Key to the native mammals of Catamarca province. Occasional Papers of the Oklahoma Museum of Natural History 4:1-16.

Brown, A. D., H. R. Grau, L. R. Malizia, and A. Grau. 2001. Argentina. Pp. 623-659 in: Bosques nublados del Neotrópico (Kappelle, M. and A. D. Brown, eds.). Editorial Instituto Nacional de Biodiversidad (INBio), Santo Domingo de Heredia, Costa Rica. Burkart, R., N. O. Bárbaro, R. O. Sánchez, and D. A. Gomez. 1999. Eco-regiones de la Argentina. Administración de Parques Nacionales. Programa Desarrollo Institucional Ambiental. Buenos Aires, Argentina.

CabrerA, A. L. 1976. Regiones fitogeográficas Argentinas. Enciclopedia Argentina de Agricultura y Jardinería 1:1-85.

Carlevari, I. 1994. La Argentina 1994: estructura humana y económica. Editorial Macchi, Buenos Aires, Argentina.

Claps, G. L., And A. G. Autino. 2012. Myodopsylla wolffsohni wolffsohni (Rothschild) (Siphonaptera, Ischnopsyllidae) sobre murciélagos de la Argentina y Uruguay. Revista de la Sociedad Entomológica Argentina 71:155-157. http://www. scielo.org.ar/pdf/rsea/v71n1-2/v71n1 2a16.pdf

Colombetti, P. L., A. G. Autino, G. L. Claps, M. I. Carma, and M. Lareschi. 2008. Primer registro de Cleopsylla townsendi (Siphonaptera: Stephanocircidae: Craneopsyllinae) en la Argentina. Revista de la Sociedad Entomológica Argentina 67:179-182.

Coyner, B. S., J. K. Braun, M. A. Mares, and V. D. Bussche, R. A. 2013. Taxonomic validity of species groups in the genus Akodon (Rodentia, Cricetidae). Zoologica Scripta 42:335-350. https:// doi.org/10.1111/zsc.12014

Del Ponte, E. 1977. Notas sobre Suctoria argentinos VIII. Revisión de las familias Hystrichopsyllidae, Stephanocircidae e Ischnopsyllidae (Ceratophylloidea). Revista del Museo argentino de Ciencias Naturales "Bernardino Rivadavia" e Instituto Nacional de Investigaciones de las Ciencias Naturales. Entomología 5:1-141.

Del Ponte, E., And M. A. Riesel. 1939. Notas sobre "Siphonaptera" argentinos. II. Primera lista de especies. Physis, Argentina 17:543-549.

Díaz, M. M, and M. Lucherinı. 2006. Familia Canidae. Pp: 89107 in: Mamíferos de Argentina. Sistemática y distribución. (Barquez, R. M., M. M. Díaz, and R. A. Ojeda, eds.) Sociedad
Argentina para el Estudio de los Mamíferos (SAREM), Tucumán, Argentina.

Díaz, M. M., AND R. M. Barquez. 1999. Contributions to the Knowledge of the mammals of Jujuy Province, Argentina. The Southwestern Naturalist 44:324-333.

Díaz, M. M., And R. M. Barquez. 2007. The Wild Mammals of Jujuy Province, Argentina: Systematics and Distribution. Pp. 417-578 in: The Quintessential Naturalist: Honoring the Life and Legacy of Oliver P. Pearson (Kelt, D. A., E. P. Lessa, J. Salazar-Bravo, and J. L. Patton, eds.). University of California Publications in Zoology. Berkeley, U.S.A.

Díaz, M. M., J. K. Braun, M. A. Mares, and R. M. Barquez. 1997. Key to mammals of Salta Province, Argentina. Occasional Papers, Oklahoma Museum of Natural History 2:1-10.

Díaz, M. M., J. K. Braun, M. A. Mares, and R. M. Barquez. 2000. An update of the taxonomy, systematics, and distribution of the mammals of Salta Province, Argentina. Occasional Papers, Sam Noble Oklahoma Museum of Natural History 10:1-52.

Díaz, M. M., R. M. Barquez, J. K. Braun, and M. A. Mares. 1999. A new species of Akodon (Muridae: Sigmodontinae) from Northwestern Argentina. Journal of Mammalogy 80:786-798.

ESRI. 2011. ArcGIS Desktop: Release 10. Redlands, California: Enviromental Systems Research Institute.

Ewers, R. M., and R. K. Didham. 2006. Confounding factors in the detection of species responses to habitat fragmentation. Biological Reviews 81:117-142.

Ezquiaga, M. C., P. M. Linardi, D. M. De Avelar, and M. Lareschi. 2015. A new species of Tunga perforating the osteoderms of its armadillo host in Argentina and redescription of the male of Tunga terasma. Medical and Veterinary Entomology 29:196-204.

Fernandez, J. E. 2019. The holistic specimen and parasites of mammals. Therya 10:65-67.

FERro, L. I. 2012. Micromamíferos del noroeste argentino: gradientes altitudinales y la transición bosque puna monte. Doctoral Thesis. San Miguel de Tucumán: Facultad de Ciencias Naturales e IML, Universidad Nacional de Tucumán, Tucumán, Argentina

Ferro, L. I., and R. M. Barquez. 2009. Species Richness of Nonvolant Small Mammals Along Elevational Gradients in Northwestern Argentina. Biotropica 41:759-767.

Flores, D. A., M. M. DíAz, And R. M. Barquez. 2000. Mouse opossums (Didelphimorphia, Didelphidae) of northwestern Argentina: Systematic and distribution. Zeitschrift für Säugetierkunde 65:1-19.

Gamboa Alurralde, S. 2017. Ensambles de Murciélagos (Mammalia, Chiroptera) en zonas con distinto grado de perturbación de las Yungas de Argentina. [Doctoral Thesis]. Facultad de Ciencias Naturales e IML, Universidad Nacional de Tucumán.

Gamboa Alurralde, S., M. F. López-Berrizbeitia, R. M. Barquez, and M. M. DíAz. 2015. Diversity and richness of small mammals at a well-conserved site of The Yungas in Jujuy Province, Argentina. Mammalia 80:253-262.

Gamboa Alurralde, S., R. T. Sánchez, R. M. Barquez, and M. M. Díaz. 2016. New records of bats (Chiroptera, Mammalia) from Argentina. Check List 12:1-11.

Gardner, A. L. 2008. Mammals of South America. Volume 1. 
Marsupials, Xenarthrans, Shrews, and Bats. The University of Chicago Press, California, USA. https://doi.org/10.7208/ chicago/9780226282428.001.0001

Hammer, O., D. A. T. Harper, and P. D. Ryan. 2001. PAST: Paleontological Statistic software package for education and data analysis. Paleontologia Eletronica 4:1-9.

HastriteR, M. W. 2001. Fleas (Siphonaptera: Ctenophthalmidae and Rhopalopsyllidae) from Argentina and Chile with two new species from the rock rat Aconaemys fuscus in Chile. Annals of Carnegie Museum 70:169-178.

Hastriter, M. W., and E. Méndez. 2000. A review of the flea genera Hectopsylla Frauenfeld and Rhynchopsyllus Haller (Siphonaptera: Pulicidae). Proceedings of the Entomological Society of Washington 102:612-624.

HASTRITER, M. W., AND M. F. Whiting. 2003. Siphonaptera (Fleas). Pp. 1040-1044 in: Encyclopedia of Insects (V. H. Resh and R. Carde Eds.). Academic Press, San Diego, United States.

Hastriter, M. W., AND R. D. SAGE. 2009. A description of two new species of Ectinorus (Siphonaptera: Rhopalopsyllidae) from Laguna Blanca National Park, Neuquén Province, Argentina. Proceedings of the Entomological Society of Washington 11:581-597.

HASTRITER, M.W., AND R. D. SAGE. 2011. Description of a new species of Ectinorus (E. spiculatus) (Siphonaptera, Rhopalopsyllidae) from Argentina and a review of the subgenus Ichyonus Smit, 1987. Zookeys 124:1-18.

Hastriter, M. W., AND R. GuerRero. 1998. A review of the bat flea genus Hormopsylla (Siphonaptera: Ischnopsyllidae). Proceedings of the Entomological Society of Washington 100:247-251.

Hastriter, M. W., M. D. Zyzak, R. Soto, R. Fernández, N. Solárzano, AND M. F. WHITING. 2002. Fleas (Siphonaptera) from Ancash department, Peru with the description of a new species, Ectinorus alejoi (Rhopalopsyllidae), and the description of the male of Plocopsylla pallas (Rothschild, 1914) (Stephanocircidae). Annals of the Carnegie Museum 71:87-106.

HopkINS, G. H., AND M. RothSCHILD. 1953. An illustrated catalogue of the Rothschild collection of fleas (Siphonaptera) in the British Museum (Natural History) with keys and short descriptions for the identification of families, genera, species and subspecies. Volume I, Tungidae and Pulicidae. The Trustees of the British Museum, London, United Kingdom.

HopkINS, G. H., AND M. RothsCHILD. 1956. An illustrated catalogue of Rothschild collection of fleas (Siphonaptera) in the British Museum (N. H.). Volume II. Coptopsyllidae, Vermipsyllidae, Stephanocircidae, Ischnopsyllidae, Hypsophthalmidae, and Xiphiopsyllidae. British Museum (Natural History) London, United Kingdom.

Hopkins, G. H., AND M. RothsCHILD. 1962. An illustrated catalogue of Rothschild collection of fleas (Siphonaptera) in the British Museum (Natural History). Vol. III. Hystrichopsyllidae. British Museum (NH), London, United Kingdom.

HopkINS, G. H., AND M. RothSCHILD. 1966. An illustrated catalogue of the Rothschild Collection of fleas (Siphonaptera) in the British Museum (Natural History). Volume IV. Hystrichopsyllidae. British Museum (NH), London, United Kingdom.

HopkINs, G. H., AND M. RothsCHILD. 1971. An illustrated catalogue of Rothschild collection of fleas (Siphonaptera) in the British
Museum (Natural History). Vol. V. Leptopsyllidae and Ancistropsyllidae. British Museum (NH), London, UK.

JAYAT, J. P., AND P. E. OrTIZ. 2010. Mamíferos del pedemonte de Yungas de la alta cuenca del río Bermejo en Argentina: una línea de base de diversidad. Mastozoología Neotropical 17:69-86.

JAYAT, J. P., AND S. PACHECO. 2006. Distribución de Necromys lactens y Phyllotis osilae (Rodentia: Cricetidae: Sigmodontinae) en el noroeste argentino: modelos predictivos basados en el concepto de nicho ecológico. Mastozoología Neotropical 3:69-88.

Jayat, J. P., P. E., Ortiz, S. E. Pacheco, and R. González. 2011. Distribution of sigmodontine rodents in Northwestern Argentina: main gaps in information and new records. Mammalia 75: 53-68.

Johnson, P. T. 1957. A classification of the Siphonaptera of South America. Memoirs of the Entomological Society of Washington 3:1-298.

Jost, L., A. ChAO, AND R. L. Chazdon. 2011. Compositional similarity and $\beta$ (beta) diversity. Pp. 66-335 in: Biological diversity: frontiers in measurement and assessment (Magurran, A. E., and B. J. McGill, eds.). Oxford University Press, Oxford, UK.

Krasnov, B. R. 2008. Funtional and Evolutionary Ecology of Fleas: A Model for Ecological Parasitology. Cambridge University Press, Cambridge, UK.

Krasnov, B. R., D. Moulllot, G. I. Shenbrot, I. S. Khokhlova, and R. Poulin. 2005. Spatial variation in species diversity and composition of flea assemblages in small mammal hosts: geographic distance or faunal similarity? Journal of Biogeography 32:633-644.

Lanzone, C., J. K. Braun, J. L. Patton, and U. F. J. Pardiñas. 2015. Genus Eligmodontia. Pp. 508-522 in: Mammals of South America. Volume 2. Rodents (Patton, J. L., U. F. J. Pardiñas, and G. D'Elía, eds.). The University of Chicago Press, Chicago, USA. LARESCHI, M., AND P. M. LINARDI. 2009. Morphological variability in Polygenis (Polygenis) platensis (Jordan and Rothschild) (Siphonaptera: Rhopalopsyllidae: Rhopalopsyllinae) and taxonomic consequences. Zootaxa 2310:35-42.

LARESCHI, M., E. SAVCHENKO, AND M. URDAPILLETA. 2019. Ectoparasites associated with sigmodontine rodents from northeastern Argentina. Therya 10:103-108. DOI: 10.12933/therya-19-758 ISSN 2007-3364

LaResCHI, M., J. P. SAnCheZ, AND A. G. Autino. 2016. Review of the fleas (Insecta: Siphonaptera) from Argentina. Zootaxa 3:239258.

LaresCHI, M., R. A. OJedA, AND P. M. LinaRDI. 2004. Flea parasites of small mammals in the Monte Desert biome in Argentina with new host and locality records. Acta Parasitológica 49:63-66.

Lareschi, M., A. G. Autino, M. M. Díaz, and R. M. Barquez. 2003. New host and locality records for mites and fleas associated with wild rodents from northwestern Argentina. Revista de la Sociedad Entomológica Argentina 62:60-64.

Lareschi, M., A. G. Autino, M. M. Díaz, and R. M. Barquez. 2011. Taxonomy and Distribution of Nonnapsylla Wagner, 1938 (Stephanocircidae: Craneopsyllinae). Journal of Parasitology 97:954-955. http://dx.doi.org/10.1645/ge-2738.1

Lareschi, M., J. P. Sanchez, M. C. Ezquiaga, A. Autino, M. M. Díaz, AND R. M. BARQuez. 2010. Fleas associated with mammals from 
northwestern Argentina, with new distributional reports. Comparative Parasitology 77:215-221.

LinaRDI, P. M., AND L. R. Guimarães. 2000. Sifonápteros do Brasil. Ed. MZUSP, FAPESP. São Paulo, Brazil.

LÓPEZ-BerRIZBEITIA, M. F. 2018. Sifonápteros de micromamíferos (Didelphimorphia, Chiroptera y Rodentia) del Noroeste Argentino: sistemática y distribución. Doctoral Thesis. San Miguel de Tucumán: Facultad de Ciencias Naturales e IML, Universidad Nacional de Tucumán. Tucumán, Argentina

López-Berrizbeitia, M. F., M. W. Hastriter, and M. M. Díaz. 2016. A new flea species of the genus Cleopsylla (Siphonaptera: Stephanocircidae) from northwestern Argentina. Journal of Parasitology 102:514-519.

López-Berrizbettia, M. F., J. P. Sanchez, R. M. Barquez, and M. M. Díaz. 2018. Descriptions of two new species of flea of the genus Plocopsylla in northwestern Argentina. Medical and Veterinary Entomology 2:1-12. doi: 10.1111/mve.12303

López-Berrizbeitia, M. F., J. P. Sanchez, R. M. Barquez, and M. M. Díaz. In press. Taxonomic revision of the flea genus Agastopsylla Jordan and Rothschild 1923 (Siphonaptera: (tenophthalmidae). Anais da Academia Brasileira de Ciências.

López-Berrizbeitia, M. F., M. M. Díaz, R. M. Barquez, and M. Lareschi. 2013a. Pulgas (Siphonaptera) parásitas de roedores (Rodentia: Cricetidae) de la provincia de Salta, Argentina: Nuevos registros de distribución. Revista de la Sociedad Entomológica Argentina 72:141-146.

López-Berrizbettia, M. F., M.W. Hastriter, R. M. Barquez, and M. M. Díaz. 2015a. A new flea of the genus Ctenidiosomus (Siphonaptera, Pygiopsyllidae) from Salta Province, Argentina. Zookeys 512:109-120.

López-Berrizbeitia, M. F., M. W. Hastriter, R. M. Barquez, and M. M. Díaz. 2019. Fleas of the genus Tetrapsyllus (Siphonaptera: Rhopalopsyllidae) associated with rodents from Northwestern Argentina. International Journal for Parasitology: Parasites and Wildlife 9:80-89.

López-BerRizbeitia, M. F., R. T. Sánchez, M. M. Díaz, And M. Lareschi. 2013b. Los ectoparásitos de La Rioja: resultados preliminares. Revista de la Asociación Parasitológica Argentina 1:40-44.

López-Berrizbeitia, M. F., R. T. Sánchez, R. M. Barquez, and M. M. Díaz. 2017. An update on the distribution and nomenclature of fleas (Order Siphonaptera) of bats (Order Chiroptera) and rodents (Order Rodentia) from La Rioja Province, Argentina. Zookeys 678:139-154. https://doi.org/10.3897/zookeys.678.12006

LóPEZ-BerRIZBeItIA, M. F., J.P. SANChez, M. M. Díaz, R. M. Barquez, and M. LARESCHI. 2015b. Redescription of Neotyphloceras crassispina hemisus Jordan (Siphonaptera: Ctenophthalmidae: Neotyphloceratini). Journal of Parasitology 10:145-149. https://doi.org/10.1645/14-648.1

MANHERT, V. 1976. Alectopsylla unisetosa nov. gen., nov. spec. (Siphonaptera, Ischnopsyllidae) from Argentina. Revue Suisse de Zoology 83:769-776.

MARDON, D. K. 1981. An illustrated catalogue of the Rothschild collection of fleas (Siphonaptera) in the British Museum (Natural History). Volume VI. Pygiopsyllidae. Trustees of The British Museum (Natural History), London, England.

Mittermeier, R. A., N. Myers, P. Robles Gil, and C. G. Mittermeier. 1999. Hotspots: earth's biologically richest and most endangered terrestrial ecoregions. Cemex, Ciudad de México, México.
Moreno, C. E. 2001. Métodos para medir la biodiversidad. M y T-Manuales y Tesis SEA, Zaragoza, Spain.

Patton, J. L., U. F. J. PARDiÑAS, AND G. D'EliA. 2015. Mammals of South America. Rodents. Vol. 2. University of Chicago Press, Chicago, Illinois, United States.

Peters, S. L., J. R. Malcolm, and B. L. Zimmerman. 2006. Effects of selective logging on bat communities in the South-eastern Amazon. Conservation Biology 20:1410-1421.

RoccatagliatA, J. A. 1998. La Argentina: Geografía general y los marcos regionales. Planeta. Buenos Aires, Argentina.

RothsChILD, M., AND R. TRAub. 1971. A revised glossary of terms used in the taxonomy and morphology of fleas. An illustrated catalogue of the Rothschild collection of fleas (Siphonaptera) in the British Museum (Natural History). Vol. V. British Museum (Natural History), London, England.

Salceda-SÁnchez, B., AND M. W. Hastriter. 2006. A list of the fleas (Siphonaptera) of Mexico with new host and distribution records. Zootaxa 1296:2-43.

SANChEZ, J. P. 2012. Sifonápteros parásitos de los roedores sigmodontinos de la Patagonia norte de la Argentina: estudios sistemáticos y ecológicos. Doctoral Thesis. Facultad de Ciencias Naturales y Museo, Universidad Nacional de La Plata, Argentina.

Sanchez, J. P., and M. Lareschi. 2013. The fleas (Insecta: Siphonaptera) parasites of sigmodontine rodents (Cricetidae) from Northern Patagonia, Argentina. Comparative Parasitology 80:110-117.

Sanchez, J. P., and M. LaresCHI. 2014a. New records of fleas (Siphonaptera: Ctenophthalmidae: Rhopalopsyllidae and Stephanocircidae) from Argentinean Patagonia, with remarks on the morphology of Agastopsylla boxi and Tiarapsylla argentina. Revista Mexicana de Biodiversidad 85:383-390. DOI:10.7550/rmb.42071

Sanchez, J. P., and M. Lareschi. 2014b. Two new species of Neotyphloceras (Siphonaptera: Ctenophthalmidae) from Argentinean Patagonia. Zootaxa 3784:159-170.

Sanchez, J. P., D. E. Udrizar-SAUthier, AND M. LaresChi. 2009. Nuevos registros de pulgas (Insecta, Siphonaptera) parásitas de roedores sigmodontinos (Cricetidae) de la Patagonia Austral, Argentina. Mastozoología Neotropical 16:243-246.

SANCHeZ, J. P., J. C. Beaucournu, AND M. LaResCHI. 2015. Revision of fleas of the genus Plocopsylla belonging to the 'angusticepslewisi' complex in the Andean biogeographic region, with the description of a new species. Medical and Veterinary Entomology 29:147-158.

Sanchez, J. P., V. Amor, E. A. Bazan-Leon, R. A. Vasquez, and M. LARESCHI. 2012. Redescription of Neotyphloceras chilensis Jordan, new status (Siphonaptera: Ctenophthalmidae: Neotyphloceratini). Zootaxa 3259:51-57.

SAndoval, M. L., M. S. SÁnCheZ, And R. M. Barquez. 2010. Mammalia, Chiroptera Blumenbach, 1779: new locality records, filling gaps, and geographic distribution maps from northern Argentina. Check List 6:64-70.

SANTILlán de ANdRÉS, S., AND R. RicCl. 1998. La región del Noroeste Argentino: paisajes heterogéneos con economía mixta. Pp. 579-612 in: La Argentina. Geografía General y los marcos regionales (Roccatagliata, J. A., ed.). Editorial Planeta Buenos Aires, Argentina.

Schramm, B. A., AND R. E. Lewis. 1988. A taxonomic revision of 
the flea genus Plocopsylla. Pp. 1-157 in: Theses Zoologicae (Fricke, R., ed.). Vol. 9. Koeltz Scientific Books, Koenigstein, Germany.

Schreiter, R., and R. C. Shannon. 1927. Un nuevo e interesante género y especie de una pulga del murciélago. Boletín del Museo de Historia Natural, Universidad Nacional de Tucumán 1:1-15.

SMIt, F. G. A. M. 1987. An illustrated catalogue of the Rothschild fleas (Siphonaptera) in the British Museum (Natural History) 7: Malacopsylloidea (Malacopsyllidae and Rhopalopsyllidae). Oxford University Press, Oxford, United Kingdom.

Steppan, S. J. and O. Ramírez. 2015. Genus Phyllotis. Pp. 535-555 in: Mammals of South America. Volume 2. Rodents (Patton, J. L., U. F. J Pardiñas, and G. D'Elía, eds.) The University of Chicago Press, Chicago, United States.

Teta, P., R. A. OJedA, S. O. Lucero, and G. D’Elía. 2017. Geographic variation in cranial morphology of the Southern Mountain Cavy, Microcavia australis (Rodentia, Caviidae): taxonomic implications, with the description of a new species. Zoological Studies Vol. 56. doi:10.6620/ZS.2017.56-29.

Teta, P., A. M. Abba, G. H. Cassini, D. A. Flores, C. A. Galliari, S. O. LuCERo, AND M. Ramírez. 2018. Lista revisada de los mamíferos de Argentina. Mastozoología Neotropical 25:163-198.

Tipton, V. J., AND C. E. Machado-Allison. 1972. F leas of Venezuela. Brigham Young University Science Bulletin, Biological Series 17:1-115.

Tipton, V. J., And E. Méndez. 1966. The fleas (Siphonaptera) of Panamá. Pp. 289-385 in: Ectoparasites of Panama (Wenzel, R. L. and V. J. Tipton, eds.). Field Museum of Natural History, Chicago, USA.

Torrella, S. A., AND J. M. AdÁmolı. 2005. Situación ambiental de la eco-región del Chaco Seco. La situación ambiental Argentina 73-75.

Torrella, S. A., R. G. Ginzburg, and J. M. Adámolı. 2007. Expansión agropecuaria en el Chaco Argentino: Amenazas para la conservación de la biodiversidad. Pp. 53-63 in: Panorama de la ecología de paisajes en Argentina y países sudamericanos (Matteucci, S.D., ed.). INTA-UNESCO, Buenos Aires, Argentina. Torrella, S. A., R. G. Ginzburg, J. M. Adámolı, and L. Galetto. 2011. Estructura, composición y estado de conservación de la comunidad de plantas leñosas del bosque de tres quebrachos en el Chaco Subhúmedo Central. Ecología Austral 21:179188.

TORRES, R., AND J. P. JaYAT. 2010. Modelos predictivos de distribución para cuatro especies de mamíferos (Cingulata, Artiodactyla y Rodentia) típicas del Chaco en Argentina. Mastozoología Neotropical 17:335-352.

Udrizar Sauthier, D., and U. F. J. Pardiñas. 2014. Estableciendo límites: distribución geográfica de los micromamíferos (Rodentia y Didelphimorphia) de Patagonia centro-oriental. Mastozoología Neotropical, Mendoza 21:79-99.

UrdapilletA, M., P. M. LinARDI, AND M. LARESCHI. 2019. Fleas associated with sigmodontine rodents and marsupials from the paranaense forest in northeastern Argentina. Acta Tropica 193:71-77.

Urquizo, J., M. M. Díaz, and R. M. Barquez. 2017. Una nueva especie de Myotis (Chiroptera: Vespertilionidae) para la Argentina. Mastozoología Neotropical 24:257-261.

Verzi, D. H., C. C. Morgan, and A. I. Olivares. 2015. The history of South American octodontoid rodents and its contribution to evolutionary generalisations. Pp. 139-163 in: Evolution of the rodents, advances in phylogeny, functional morphology and development (Cox, P., and L. Hautier, eds.). Cambridge University Press, United Kingdom, UK.

Voss, R. S., AND S. A. JANSA. 2009. Phylogenetic relationships and classification of didelphid marsupials, an extant radiation of New World metatherian mammals. Bulletin of the American Museum of Natural History 322:1-177.

Whiting, M. F., A. S. Whiting, M. W. Hastriter, and K. Dittmar. 2008. A molecular phylogeny of fleas (Insecta: Siphonaptera): origins and host associations. Cladistics 24:677-707.

Associated editor: Jesús Fernández

Submitted: July 4, 2019; Reviewed: July 29, 2019;

Accepted:August 20, 2019; Published on line: September 10, 2019. 


\section{APPENDIX I}

List of localities

Alphabetical list of localities of each province of northwestern Argentina: Specific locality, Department between parentheses, Geographic coordinates and Elevation are included.

\section{Catamarca}

1. 17 km N Barranca Larga (Belén) -260 51'11.6"S, -66 45'18.8" $\mathrm{W}, 3,219 \pm 51 \mathrm{~m}$.

2. 21 km SO El Desmonte (Santa María) -260 59' 57.5" S, -66 $14^{\prime}$ 33.7"W, 2,172 $\pm 150 \mathrm{~m}$.

3. $22 \mathrm{~km}$ al SE de Villa de Escaba sobre ruta provincial № 9 (Paclín) -270 47' 48.48" S, -65-46'56.70"W, 538 m.

4. $3.4 \mathrm{~km}$ al $\mathrm{S}$ de la unión entre las rutas provinciales 18 y 9 , sobre ruta provincial № 18 (Paclín) $-27^{\circ} 49^{\prime} 48.3^{\prime \prime} \mathrm{S},-65^{\circ} 47^{\prime}$ $53.3^{\prime \prime} \mathrm{W}, 1,529 \pm 53 \mathrm{~m}$.

5. 5.2 km S El Bolsón (Belén) -270 02' 36.6" S, -66 47' 14" W, $2,404 \pm 55 \mathrm{~m}$.

6. 9.2 km O Andalgalá (Andalgalá) - $27^{\circ} 35^{\prime} 33.1^{\prime \prime} \mathrm{S},-66^{\circ} 24^{\prime} 56.2^{\prime \prime}$ W, 1,089 $\pm 150 \mathrm{~m}$.

7. Chumbicha (Capayán) -28० 54'S, -660 15’W, 379 m.

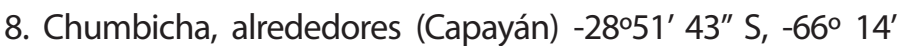
$41.9^{\prime \prime} \mathrm{W}, 407 \mathrm{~m}$.

9. Cumbre de Humaya (Ambato) $-27^{\circ} 56^{\prime} 12.08^{\prime \prime} \mathrm{S},-65^{\circ} 56^{\prime} 46.30^{\prime \prime}$ W, $1900 \mathrm{~m}$.

10. El Rodeo (Ambato) $-28^{\circ} 13^{\prime} \mathrm{S},-65^{\circ} 52^{\prime} \mathrm{W}, 1361 \mathrm{~m}$.

11. Estancia Narváez, $5.5 \mathrm{~km} \mathrm{~N}$ Las Chacritas sobre ruta provincial № 1 (Ambato) -270 39' 46.3" S, -650 56' 34.2" W, $1782 \pm 150 \mathrm{~m}$.

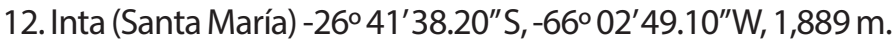

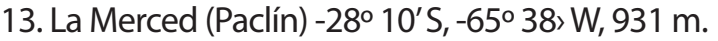

14. La Puerta (Ambato) $-28^{\circ} 13^{\prime} \mathrm{S},-65^{\circ} 24^{\prime} \mathrm{W}, 797 \mathrm{~m}$.

15. Laguna Blanca (Belén) -260 34' 53.4" S, -660 56' 38.6" W, $3,350 \pm 70 \mathrm{~m}$.

16. Las Juntas (Ambato) $-28^{\circ} 06^{\prime} \mathrm{S},-65^{\circ} 55^{\prime} \mathrm{W}, 1,750 \mathrm{~m}$.

17. Otro Cerro (Capayán) -28 48' S, -66 17’W, 2,154 m.

18. Otro Cerro, Rancho de los Crisho (Capayán) -28 41'33.06"S, $-66^{\circ} 15^{\prime} 9.00^{\prime \prime} \mathrm{W}, 2,300 \mathrm{~m}$.

19. Pasto Ventura (Antofagasta de la Sierra) $-26^{\circ} 41^{\prime} 37.4^{\prime \prime} \mathrm{S}$, $-67^{\circ} 10^{\prime} 55.6^{\prime \prime} \mathrm{W}, 3,831 \pm 32 \mathrm{~m}$.

20. Paycuqui (Antofagasta de la Sierra) $-25^{\circ} 54^{\prime} 53^{\prime \prime} \mathrm{S},-67^{\circ} 21^{\prime} 15^{\prime \prime}$ W, 3,664 $\pm 22 \mathrm{~m}$.

\section{Jujuy}

$21.17 \mathrm{~km}$ al O y $3 \mathrm{~km}$ al S de la Quiaca, sobre ruta provincial № 5 (Yavi) $-22^{\circ} 09^{\prime} \mathrm{S},-65^{\circ} 44^{\prime} \mathrm{W}, 3,631 \mathrm{~m}$.

$22.3 \mathrm{~km}$ al E de Purmamarca por ruta nacional № 52 (Tumbaya) $-23^{\circ} 43^{\prime} 47.11^{\prime \prime} \mathrm{S},-65^{\circ} 31^{\prime} 11.12^{\prime \prime} \mathrm{W}, 2,453 \mathrm{~m}$.
23. 3 km del cruce Río Las Capillas y ruta provincial № 20 (Dr. Manuel Belgrano) -24 5' 35.77" S, -65० 9' 7.86"W, 1,141 m.

24. $5 \mathrm{~km}$ NE de Humahuaca (Humahuaca) $-23^{\circ} 13^{\prime} \mathrm{S},-65^{\circ} 20^{\prime} \mathrm{W}$, $3,103 \mathrm{~m}$.

25. $6.8 \mathrm{~km}$ al SE de Suripujio, sobre ruta provincial $\mathrm{N}^{\circ} 5$ (Yavi) $-22^{\circ} 13^{\prime} 27^{\prime \prime} \mathrm{S},-65^{\circ} 16^{\prime} 12.2^{\prime \prime} \mathrm{W}, 3,991 \pm 29 \mathrm{~m}$.

26. 9 km NO Bárcena (Tumbaya) -23 67' 5.9" S, -650 30' 1.2"W, $2,655 \pm 73 \mathrm{~m}$.

27. Abra de Santa Laura, límite entre Salta y Jujuy, sobre ruta

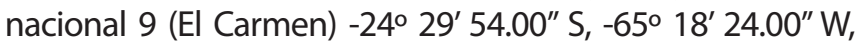
$1,381 \mathrm{~m}$.

28. Arroyo La Horqueta, $6 \mathrm{~km}$ al SE de las Lagunas de Yala (Dr. Manuel Belgrano) $-24^{\circ} 07^{\prime} \mathrm{S},-65^{\circ} 27^{\prime} \mathrm{W}, 1,950 \mathrm{~m}$.

29. Arroyo Los Matos, 7 km N de Las Capillas (Dr. Manuel Belgrano) $-24^{\circ} 04^{\prime} 27.93^{\prime \prime} \mathrm{S},-65^{\circ} 08^{\prime} 42.08^{\prime \prime} \mathrm{W}, 1,193 \mathrm{~m}$.

30. Casa Colorada, $\sim 2 \mathrm{~km}$ al $\mathrm{N}$ de Alfarcito (Tilcara) $-23^{\circ} 35^{\prime} \mathrm{S}$, $-65^{\circ} 21^{\prime} \mathrm{W}, 3,157 \mathrm{~m}$.

31. Cerro El Morado, $11 \mathrm{~km}$ al NO de San Antonio, sobre Río El Morado (San Antonio) $-24^{\circ} 19^{\prime} \mathrm{S},-65^{\circ} 24^{\prime} \mathrm{W}, 1,643 \mathrm{~m}$.

32. Chilcayoc (Tumbaya) $-23^{\circ} 56^{\prime} 30^{\prime \prime} \mathrm{S},-65^{\circ} 28^{\prime} 33^{\prime \prime} \mathrm{W}$, $2,239 \pm 50 \mathrm{~m}$.

33. Cuesta de Jaire (Dr. Manuel Belgrano) -24 01' 29.14" S, $065^{\circ}$ $24^{\prime} 50.70^{\prime \prime} \mathrm{W}, 1,961 \mathrm{~m}$.

34. Cuesta de Lipán, $15 \mathrm{~km} O$ de Purmamarca, sobre ruta 52, (Tumbaya) $-23^{\circ} 40^{\prime} \mathrm{S},-65^{\circ} 35^{\prime} \mathrm{W}, 3,092 \mathrm{~m}$.

35. Cuesta del Hurón, $29 \mathrm{~km}$ al $\mathrm{W}$ de Cieneguillas, sobre ruta provincial 64 (Santa Catalina) $-22^{\circ} 06^{\prime} \mathrm{S},-66^{\circ} 03^{\prime} \mathrm{W}, 3,829 \mathrm{~m}$.

36 . Curques, $24 \mathrm{~km}$ al $\mathrm{N}$ de Susques sobre ruta 74 (Susques) -230 $14^{\prime} \mathrm{S},-66^{\circ} 23^{\prime} \mathrm{W}, 3,917 \mathrm{~m}$.

37. El Chaguaral, cerca de Villa Carolina (San Pedro) $-24^{\circ} 12^{\prime} \mathrm{S}$, $-64^{\circ} 49^{\prime} \mathrm{W}, 514 \mathrm{~m}$.

38. Laguna La Brea, $25 \mathrm{~km}$ antes de Palma Sola (Santa Bárbara) $-23^{\circ} 56^{\prime} \mathrm{S},-64^{\circ} 28^{\prime} \mathrm{W}, 882 \mathrm{~m}$.

39. La Quiaca, $17 \mathrm{~km}$ O y $3 \mathrm{~km} \mathrm{~S}$, sobre ruta provincial 5, (Yavi) $-22^{\circ} 09^{\prime} \mathrm{S},-65^{\circ} 44^{\prime} \mathrm{W}, 3,630 \mathrm{~m}$

40. Parque Provincial Potrero de Yala (Dr. Manuel Belgrano) -24 $06^{\prime} 45.81^{\prime \prime} \mathrm{S},-65^{\circ} 28^{\prime} 41.05^{\prime \prime} \mathrm{W}, 2,031 \mathrm{~m}$.

41. Pucará de Tilcara (Tilcara) $-23^{\circ} 35^{\prime} 09.79^{\prime \prime} \mathrm{S},-65^{\circ} 24^{\prime} 09.53^{\prime \prime} \mathrm{W}$, $2,508 \mathrm{~m}$.

42. Quebrada Seca, Alfarcito, $10 \mathrm{~km}$ al O de Tilcara (Tilcara) -23० $34^{\prime} 40.53^{\prime \prime} \mathrm{S},-65^{\circ} 29^{\prime} 29.58^{\prime \prime} \mathrm{W}, 3,558 \mathrm{~m}$.

43. Reserva Provincial Olaroz-Cauchari (Susques) $-23^{\circ} 19^{\prime} \mathrm{S},-66^{\circ}$ $35^{\prime} \mathrm{W}, 3,963 \mathrm{~m}$.

44. Río Blanco, $9 \mathrm{~km}$ SO San Antonio (San Antonio) -24 24' $52.80^{\prime \prime} \mathrm{S},-65^{\circ} 22^{\prime} 34.20^{\prime \prime} \mathrm{W}, 1,456 \mathrm{~m}$.

45. Río Las Capillas, $15 \mathrm{~km}$ al $\mathrm{N}$ de Las Capillas, por ruta provincial 20 (Dr. Manuel Belgrano) -24 $02^{\prime} \mathrm{S} 65^{\circ} 07^{\prime} \mathrm{W}, 1,059 \mathrm{~m}$.

46. Río Lavayén, aproximadamente $1 \mathrm{~km}$ al $\mathrm{N}$ de Santa Rita (San Pedro) $-24^{\circ} 28^{\prime} \mathrm{S},-64^{\circ} 48^{\prime} \mathrm{W}, 553 \mathrm{~m}$.

47. Río Tiraxi, $1.5 \mathrm{~km}$ al E de Tiraxi, sobre ruta provincial N ${ }^{\circ} 29$ (Dr. Manuel Belgrano) $-23^{\circ} 59^{\prime} \mathrm{S},-65^{\circ} 19^{\prime} \mathrm{W}, 1,669 \mathrm{~m}$. 
48. Ruta 83 camino a Valle Grande, $9 \mathrm{~km}$ al $\mathrm{N}$ de San Francisco (Valle Grande) $-23^{\circ} 35^{\prime} \mathrm{S},-64^{\circ} 58^{\prime} \mathrm{W}, 1,448 \mathrm{~m}$.

49. Salar Cauchari, $31 \mathrm{~km}$ al $\mathrm{N}$ de Cauchari, sobre ruta provincial № 70 (Susques) $-23^{\circ} 50^{\prime} \mathrm{S},-66^{\circ} 47^{\prime} \mathrm{W}, 3,915 \mathrm{~m}$.

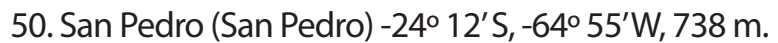

51. San Salvador de Jujuy (Dr. Manuel Belgrano) $-24^{\circ} 12^{\prime} \mathrm{S},-65^{\circ}$ $19^{\prime} \mathrm{W}, 1,357 \mathrm{~m}$.

52. Sierra de Tilcara, El Hueco, $21 \mathrm{~km}$ SE de Tilcara (Tilcara) $-23^{\circ}$ $42^{\prime} 26.82^{\prime \prime} \mathrm{S},-65^{\circ} 14^{\prime} 42.54^{\prime \prime} \mathrm{W}, 3,044 \mathrm{~m}$.

53. Sierra de Tilcara, Toro Arita, 12 km ESE de Maimará, 14 km ESE de Tilcara (Tilcara) $-23^{\circ} 39^{\prime} 55.56^{\prime \prime} \mathrm{S},-65^{\circ} 17^{\prime} 55.02^{\prime \prime} \mathrm{W}$, $4,092 \mathrm{~m}$.

54. Sierra de Zenta, ruta provincial 13 , entre Chaupe Rodeo e Iruya, $12 \mathrm{~km} \mathrm{~N}$ de Chaupe Rodeo (Humahuaca) $-22^{\circ} 53^{\prime} \mathrm{S}$, $-65^{\circ} 15^{\prime} \mathrm{W}, 3,982 \mathrm{~m}$.

55. Sobre ruta $40,29 \mathrm{~km}$ al $\mathrm{N}$ del empalme con ruta 52 (Tumbaya) $-23^{\circ} 24^{\prime} \mathrm{S},-65^{\circ} 46^{\prime} \mathrm{W}, 3,479 \mathrm{~m}$.

56. Villa Carolina, Río Lavallén, a unos $20 \mathrm{~km}$ al E de San Pedro de Jujuy (San Pedro) -240 13' 09.02" S, -64 39' $58.50^{\prime \prime} \mathrm{W}, 485 \mathrm{~m}$.

La Rioja

$57.1 \mathrm{~km}$ al $\mathrm{N}$ de Los Tambillos (Coronel Felipe Varela) $-29^{\circ} 22^{\prime} \mathrm{S}$, $-67^{\circ} 47^{\prime} \mathrm{W}, 1,939 \mathrm{~m}$.

58. $2 \mathrm{~km}$ al E de Malanzán, camping El Descanso (General Facundo J. Quiroga) -30 48' 37.7"S, -66 34' 40.3"W, $957 \mathrm{~m}$.

$59.2 \mathrm{~km}$ al $\mathrm{S}$ pasando Río de La Punta sobre ruta provincial $\mathrm{N}^{\circ} 7$ (Arauco) $-28^{\circ} 45^{\prime} 28.8^{\prime \prime} \mathrm{S},-66^{\circ} 47^{\prime} 09.3^{\prime \prime} \mathrm{W}, 996 \mathrm{~m}$.

60. $2 \mathrm{~km}$ al $\mathrm{S}$ de la entrada al Parque Geológico Sanagasta, sobre ruta nacional 75 (Sanagasta) -29० 16' 48.73" S, -670 2' $11.92 " \mathrm{~W}, 1,122 \mathrm{~m}$.

61. 26 km SO Quimilo (Chamical) -30 $02^{\prime} 43.4^{\prime \prime} \mathrm{S},-65^{\circ} 31^{\prime} 13.4^{\prime \prime}$ W, $581 \mathrm{~m}$.

$62.4 \mathrm{~km}$ al O de Anillaco, Reserva Aguada de las Alturas (Castro Barros) $-28^{\circ} 47^{\prime} 56.52^{\prime \prime} \mathrm{S},-66^{\circ}$ 59' 44.94"W, 1,738m.

$63.5 \mathrm{~km}$ al $\mathrm{S}$ del Cañón del Ocre (Famatina) -28० 51'55.9"S, -670 $41^{\prime} 26.3^{\prime \prime} \mathrm{W}, 2,495 \mathrm{~m}$.

$64.700 \mathrm{~m}$ al E de RN 40 (San Blas de los Sauces) -28 24' 17.4" S, $-67^{\circ} 04^{\prime} 48.4^{\prime \prime} \mathrm{W}, 1,123 \mathrm{~m}$.

65. $8 \mathrm{~km}$ al NE del Cañón del Ocre (Famatina) -28 57' 37.3" S, $-67^{\circ} 41^{\prime} 26.3^{\prime \prime} \mathrm{W}, 3,127 \mathrm{~m}$.

66. A $800 \mathrm{~m}$ al E de la entrada de Anillaco (Castro Barros) $-28^{\circ} 48^{\prime}$ 34.32" S, -660 55'11.58"W, 1,329 m.

67. Ambil, $23 \mathrm{~km}$ al S de Catuna (General Ocampo) -31 $07^{\prime} 36.5^{\prime \prime}$ $\mathrm{S},-66^{\circ} 20^{\prime} 45.3^{\prime \prime} \mathrm{W}, 597 \mathrm{~m}$.

68. Anillaco, $1.7 \mathrm{~m}$ al E del CRILAR (Castro Barros) -28 48' 46.00" $\mathrm{S},-66^{\circ} 55^{\prime} 50.44^{\prime \prime} \mathrm{W}, 1,357 \mathrm{~m}$.

69. Anillaco, $500 \mathrm{~m}$ al $\mathrm{O}$ de la plaza de Anillaco (Castro Barros) $-28^{\circ} 48^{\prime} 40.30^{\prime \prime} \mathrm{S},-66^{\circ} 55^{\prime} 55.55^{\prime \prime} \mathrm{W}, 500 \mathrm{~m}$.

70. Anillaco, atrás del cementerio (Castro Barros) -28 48 49.04" $\mathrm{S},-66^{\circ} 56^{\prime} 0.75^{\prime \prime} \mathrm{W}, 1,365 \mathrm{~m}$.
71. Chepes, puesto La Escondida, $42 \mathrm{~km}$ al $\mathrm{S}$ de Chepes (Rosario

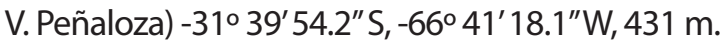

72. Cuesta La Cébila, $22 \mathrm{~km}$ al NW de Chumbicha, sobre ruta 60 (Capital) $-28^{\circ} 50^{\prime} \mathrm{S},-66^{\circ} 24^{\prime} \mathrm{W}, 850 \mathrm{~m}$.

73. Guayapa, $13 \mathrm{~km}$ SO de Patquía cerca de la ruta 150 (Independencia) $-30^{\circ} 07^{\prime} 13.92^{\prime \prime} \mathrm{S},-66^{\circ} 58^{\prime} 25.34^{\prime \prime} \mathrm{W}, 502 \mathrm{~m}$.

74. Olta, Dique de Olta (General Belgrano) $-30^{\circ} 38^{\prime} 22.55^{\prime \prime} \mathrm{S},-66^{\circ}$ $17^{\prime} 46.6^{\prime \prime} \mathrm{W}, 635 \mathrm{~m}$.

75. Puesto Tres Piedras (Famatina) -28 50'39.8'S , 670 46 58.7" $\mathrm{W}, 3,304 \mathrm{~m}$.

76. Quebrada de Santo Domingo $30 \mathrm{~km}$ al SO de Jagué (Vinchina) $-28^{\circ} 31^{\prime} 34.7^{\prime \prime} \mathrm{S},-68^{\circ} 46^{\prime} 13.8^{\prime \prime} \mathrm{W}, 3,131 \mathrm{~m}$.

77. Ruta Provincial $11, \mathrm{~km} 81$, El Potrerillo, río El Potrerillo (Famatina) $-28^{\circ} 23^{\prime} 52.6^{\prime \prime} \mathrm{S},-67^{\circ} 40^{\prime} 35.6^{\prime \prime} \mathrm{W}, 1,685 \mathrm{~m}$.

78. Ulapes, $1 \mathrm{~km}$ al $O$ de la plaza principal de Ulapes (San Martín) $-31^{\circ} 34^{\prime} 35^{\prime \prime} \mathrm{S},-66^{\circ} 14^{\prime} 55^{\prime \prime} \mathrm{W}, 493 \mathrm{~m}$.

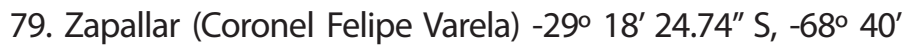
9.24"W, 1,634 m.

Salta

80. 12.6 km O de Piquirenda Viejo (San Martín) -22 20' S, $-63^{\circ}$ $50^{\prime} \mathrm{W}, 750 \mathrm{~m}$.

81. 26 km NO de Santa Rosa de los Pastos Grandes (Los Andes) $-24^{\circ} 30^{\prime} \mathrm{S},-66^{\circ} 47^{\prime} 24^{\prime \prime} \mathrm{W}, 3,949 \pm 17 \mathrm{~m}$.

$82.3 \mathrm{~km}$ al $\mathrm{N}$ de Potrerillos sobre ruta provincial $\mathrm{N}^{\circ} 6$ (Candelaria) $-26^{\circ} 03^{\prime} 52.9^{\prime \prime} \mathrm{S},-65^{\circ} 30^{\prime} 01.2^{\prime \prime} \mathrm{W}, 1,214 \pm 94 \mathrm{~m}$.

83. $7.8 \mathrm{~km}$ al NNE de Pampa Grande, sobre ruta provincial $\mathrm{N}^{\circ} 6$,

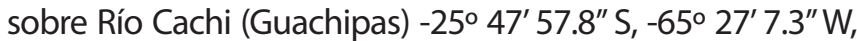
$1,750 \pm 72 \mathrm{~m}$.

84. $8 \mathrm{~km}$ O de Piquirenda Viejo (San Martín) $-22^{\circ} 21^{\prime} \mathrm{S},-63^{\circ} 50^{\prime}$ $\mathrm{W}, 678 \mathrm{~m}$.

85. A $43.7 \mathrm{~km}$ del cruce de las rutas 50 y 18 , camino a Isla

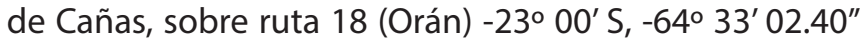
W, $679 \mathrm{~m}$.

86. Aguas Blancas, estación de aforo a $30 \mathrm{~m}$ del puente internacional sobre ruta provincial $N^{\circ} 19$, a orillas del Río Bermejo

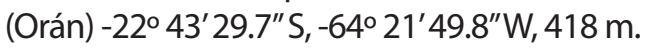

87. Aproximadamente $3 \mathrm{~km} \mathrm{~N}$ Cachi adentro (Cachi) -25० 04' 24.8"S, $-66^{\circ} 12^{\prime} 40.2^{\prime \prime} \mathrm{W}, 2,724 \pm 51 \mathrm{~m}$.

88. Aproximadamente $15 \mathrm{~km}$ al $\mathrm{O}$ de Escoipe, sobre ruta pro-

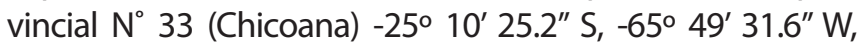
$2,680 \pm 73 \mathrm{~m}$.

89. Aproximadamente $2 \mathrm{~km}$ al $\mathrm{N}$ y $6 \mathrm{~km}$ al $\mathrm{O}$ de Metán, sobre

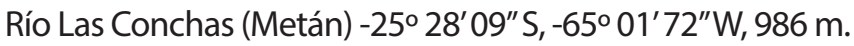

90. Cerillos (=Cerrillos) $-24^{\circ} 55^{\prime} \mathrm{S},-65^{\circ} 30^{\prime} \mathrm{W}, 1,250 \mathrm{~m}$.

91. Cuesta Chica, $35 \mathrm{~km} O$ del Oculto, 4 km E de San Andrés (Orán) -23 4' 20.51"S, -640 50'12.75"W, 1,539 m.

92. El Quebrachal (Anta) $-25^{\circ} 21^{\prime} \mathrm{S},-64^{\circ} 02^{\prime} \mathrm{W}, 337 \mathrm{~m}$.

93. El Oculto, ruta provincial $N^{\circ} 18, \mathrm{~km} 25$ sobre Río Blanco (camino a San Andrés) (Orán) -23 6' 22.21" S, -64 32' 25.40" W, $528 \mathrm{~m}$. 
94. Finca Barba Yaco, $8.5 \mathrm{~km}$ SE Ojo de Agua (Rosario de la Frontera) $-25^{\circ} 58^{\prime} 36.8^{\prime \prime} \mathrm{S},-64^{\circ} 55^{\prime} 36.9^{\prime \prime} \mathrm{W}, 1,347 \pm 57 \mathrm{~m}$.

95. Finca Chato Méndez (Orán) -23० 13'34.67" S, -640 13'1.59" W, $311 \mathrm{~m}$.

96. Gran Chaco (San Martín) -23 36' S, -62 35'W, 211 m.

97. Hipólito Yrigoyen (Orán) -23० 14'34.47"S, -640 16' 14.67"W, $328 \mathrm{~m}$.

98. Joaquin V. González (Anta) -250 $06^{\prime} \mathrm{S},-64^{\circ} 07^{\prime} \mathrm{W}, 379 \mathrm{~m}$.

99. La Estrella (Orán) -23 48' 51.06"S, -64 05'50.49”W, 400 m.

100. Laguna de Pintascayo, $1.5 \mathrm{~km} \mathrm{~N}$ sobre Río Pescado, frente a Quebrada del Café (Orán) -220 51'66"S, -64 29'43"W, 465 m.

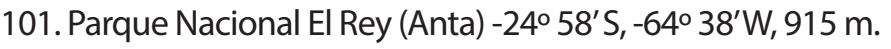

102. Pintascayo, Campamento Lima (Propiedad de GMF S.A.)

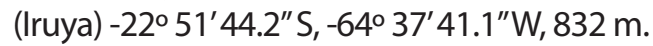

103. Río El Naranjo, $14 \mathrm{~km}$ al $O$ de ruta provincial № 5 , sobre camino de acceso a Parque Nacional El Rey (Anta) -24 $58^{\prime} \mathrm{S}$, $-64^{\circ} 38^{\prime} \mathrm{W}, 915 \mathrm{~m}$.

104. Río Los Sauces, 12 km NO del Jardín, ruta 6 km 110 (Candelaria) $-26^{\circ} 4^{\prime} 33.6^{\prime \prime} \mathrm{S},-65^{\circ} 28^{\prime} 58.8^{\prime \prime} \mathrm{W}, 993 \mathrm{~m}$.

105. Rosario de la Frontera (Rosario de la Frontera) $-25^{\circ} 48^{\prime} \mathrm{S}$, $-64^{\circ} 58^{\prime} \mathrm{W}, 792 \mathrm{~m}$.

106. Rosario de Lerma (Rosario de Lerma) $-24^{\circ} 59^{\prime} \mathrm{S},-65^{\circ} 35^{\prime} \mathrm{W}$, $1,330 \mathrm{~m}$.

107. Salta (Capital) $-24^{\circ} 46^{\prime} \mathrm{S},-65^{\circ} 28^{\prime} \mathrm{W}, 1,258 \mathrm{~m}$.

108. Vega Cortadera (Los Andes) $-25^{\circ} 07^{\prime} 13^{\prime \prime} \mathrm{S},-67^{\circ} 02^{\prime} 39^{\prime \prime} \mathrm{W}$, $3,897 \pm 16 \mathrm{~m}$.

\section{Santiago del Estero}

109. El Ojito (Pellegrini) $-26^{\circ} 01^{\prime} \mathrm{S},-63^{\circ} 45^{\prime} \mathrm{W}, 255 \mathrm{~m}$.

110. El Quemado (Figueroa) $-27^{\circ} 06^{\prime} \mathrm{S},-63^{\circ} 33^{\prime} \mathrm{W}, 174 \mathrm{~m}$.

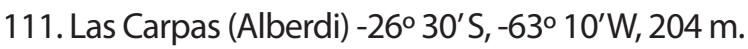

112. La Puerta, $27 \mathrm{~km}$ al SE de Las Termas de Río Hondo, sobre ruta nacional № 9 (Río Hondo) -270 38' 12" S, -640 36' 39" W, $284 \mathrm{~m}$.

113. Pozo Betbeder (Pellegrini) $-26^{\circ} 23^{\prime} \mathrm{S},-64^{\circ} 20^{\prime} \mathrm{W}, 326 \mathrm{~m}$.

114. Salinas de Ambargasta, $\sim 8$ km SE Cerro Rico (Choya) -29० $03^{\prime} 33.6^{\prime \prime} \mathrm{S},-64^{\circ} 38^{\prime} 01.5^{\prime \prime} \mathrm{W}, 141 \pm 22 \mathrm{~m}$.

115. Sumampa (Quebrachos) $-29^{\circ} 22^{\prime} \mathrm{S},-63^{\circ} 28^{\prime} \mathrm{W}, 246 \mathrm{~m}$.

116. San Pedro de Guasayán, en el techo de un galpón abandonado (Guasayán) -27052'S, -64 51'W, $481 \mathrm{~m}$.

\section{Tucuman}

117. 11 km S Tafí del Valle (Tafí del Valle) - $26^{\circ} 53^{\prime} 34.90^{\prime \prime} \mathrm{S},-65^{\circ} 45^{\prime}$ $52.28^{\prime \prime} \mathrm{W}, 2,278 \mathrm{~m}$.

118. $1.9 \mathrm{~km}$ NE Hualinchay sobre ruta provincial $\mathrm{N}^{\circ} 311$ (Trancas) $-26^{\circ} 18^{\prime} 44^{\prime \prime} \mathrm{S},-65^{\circ} 35^{\prime} 52^{\prime \prime} \mathrm{W}, 1,732 \pm 150 \mathrm{~m}$.

$119.26 \mathrm{~km}$ al $\mathrm{S}$ de San Pedro de Colalao sobre ruta provincial $\mathrm{N}^{\circ}$ 364 (Trancas) $-26^{\circ} 23^{\prime} 0.80^{\prime \prime} \mathrm{S},-65^{\circ} 33^{\prime} 18.80^{\prime \prime} \mathrm{W}, 1,540 \pm 64 \mathrm{~m}$.

120. Arroyo El Saltón, Reserva Provincial Santa Ana (Río Chico) $-27^{\circ} 28^{\prime} \mathrm{S},-65^{\circ} 45^{\prime} \mathrm{W}, 523 \mathrm{~m}$.
121. Arroyo Mista (Leales) $-27^{\circ} 13^{\prime} \mathrm{S},-65^{\circ} 10^{\prime} \mathrm{W}, 323 \mathrm{~m}$.

122. Cañada del Fuerte Viejo, Cerro Muñoz (Tafí del Valle) $-26^{\circ}$ $53^{\prime} 41^{\prime \prime} \mathrm{S}, 065^{\circ} 48^{\prime} 40.32^{\prime \prime} \mathrm{W}, 3,300 \mathrm{~m}$.

123. Cerro San Javier (Tafí Viejo) $-26^{\circ} 33^{\prime} \mathrm{S},-65^{\circ} 26^{\prime} \mathrm{W}, 1,780 \mathrm{~m}$.

124. Cerro San Javier, a unos $20 \mathrm{~km}$ al O de San Miguel de Tucu-

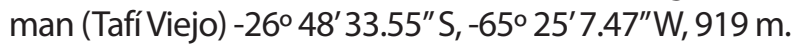

125. Ciénaga Escondida (Tafí del Valle) $-26^{\circ} 53^{\prime} 33.69^{\prime \prime} \mathrm{S},-65^{\circ} 49^{\prime}$ 25.48"W, 3,781 m.

126. Ciénaga Grande, San José de Chasquivil (Tafí Viejo) -260 41' $8.74^{\prime \prime} \mathrm{S},-65^{\circ} 39^{\prime} 30.79^{\prime \prime} \mathrm{W}, 2,830 \mathrm{~m}$.

127. Cuesta del Clavillo, $5 \mathrm{~km}$ al SO de La Banderita (Andalgalá) $-27^{\circ} 20^{\prime} \mathrm{S},-66^{\circ} 00^{\prime} \mathrm{W}, 1,910 \mathrm{~m}$.

128. Dique Escaba (Alberdi) $-27^{\circ} 40^{\prime} \mathrm{S},-65^{\circ} 45^{\prime} \mathrm{W}, 656 \mathrm{~m}$.

129. Dique San Ignacio (La Cocha) $-27^{\circ} 46^{\prime} \mathrm{S},-65^{\circ} 37^{\prime} \mathrm{W}, 501 \mathrm{~m}$.

130. El Ceibal Chico, $4 \mathrm{~km}$ al E de la rotonda de Lules por ruta provincial 321 y $1.5 \mathrm{~km}$ al S, por calle Julio C. Berrizbeitia (Lules) $-26^{\circ} 56^{\prime} 57.42^{\prime \prime} \mathrm{S},-65^{\circ} 18^{\prime} 9.50^{\prime \prime} \mathrm{W}, 393 \mathrm{~m}$.

131. El Papal, Parque Nacional Campo de Los Alisos (Chicligasta) $-27^{\circ} 11^{\prime} 29.88^{\prime \prime} \mathrm{S},-65^{\circ} 57^{\prime} 1.62^{\prime \prime} \mathrm{W}, 2,175 \mathrm{~m}$.

132. Escaba de Abajo, casa abandonada a $150 \mathrm{~m}$ de la Hostería Eskay Apu (Alberdi) -270 40'12.03"S, -650 45'52.42"W, 668 m.

133. Los Cardones (Tafí del Valle) -26 31'08.12" $\mathrm{S},-65^{\circ} 59^{\prime} 50.81^{\prime \prime}$ $\mathrm{W}, 1,780 \mathrm{~m}$.

134. Lagunas de Huaca Huasi, Cumbres Calchaquíes (Tafí Viejo) $-26^{\circ} 39^{\prime} \mathrm{S},-65^{\circ} 43^{\prime} \mathrm{W}, 4,169 \mathrm{~m}$.

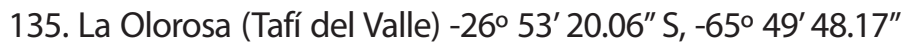
$\mathrm{W}, 3,940 \mathrm{~m}$.

136. Los Planchones, Cerro Muñoz, aproximadamente $15 \mathrm{~km}$ O de Rodeo Grande (Tafí del Valle) -26 53' $32.08^{\prime \prime} \mathrm{S},-65^{\circ} 50^{\prime}$ $41.72 " \mathrm{~W}, 4,325 \mathrm{~m}$.

137. La Quebradita (Tafí del Valle) $-26^{\circ} 49^{\prime} 34.11^{\prime \prime} \mathrm{S},-65^{\circ} 42^{\prime}$ $56.69 " \mathrm{~W}, 2,304 \mathrm{~m}$.

138. Las Tipas, Parque Biológico Sierra de San Javier (Tafí Viejo) $-26^{\circ} 39^{\prime} 16.20^{\prime \prime} \mathrm{S},-65^{\circ} 22^{\prime} 57.60^{\prime \prime} \mathrm{W}, 968 \mathrm{~m}$.

139. Los Chorrillos 13 km NO, límite norte estancia Los Chorrillos (Burruyacú) -260 16'10.96"S, -65 0'53.31"W, 1,592 m.

140. Parque Nacional Campo de Los Alisos, El Kerqueo (Chicligasta) $-27^{\circ} 10^{\prime} 21.30^{\prime \prime} \mathrm{S},-65^{\circ} 58^{\prime} 45^{\prime \prime} \mathrm{W}, 3,156 \mathrm{~m}$.

141. Parque Provincial El Cochuna, camping (Chicligasta) $-27^{\circ}$ $41^{\prime} \mathrm{S},-65^{\circ} 46^{\prime} 30^{\prime \prime} \mathrm{W}, 748 \mathrm{~m}$.

142. Peña Colorada (Tafí del Valle) $-26^{\circ} 53^{\prime} 12.99^{\prime \prime} \mathrm{S},-65^{\circ} 50^{\prime}$ 14.47"W, 4,138 m.

143. Peña Con Gente, Cerro Muñoz (Tafí del Valle) -26 53'30.15" $\mathrm{S},-65^{\circ} 50^{\prime} 25.60^{\prime \prime} \mathrm{W}, 4,250 \mathrm{~m}$.

144. Pie de la Cuesta a Chasquivil, $5 \mathrm{~km}$ de la Hoyada sobre Río Hoyada (Tafí Viejo) $-26^{\circ} 39^{\prime} 37.6^{\prime \prime} \mathrm{S},-65^{\circ} 33^{\prime} 65^{\prime \prime} \mathrm{W}, 1,700 \mathrm{~m}$.

145. Piedra Blanca (Tafí Viejo) $-26^{\circ} 41^{\prime} 8.74^{\prime \prime} \mathrm{S},-65^{\circ} 39^{\prime} 30.80^{\prime \prime} \mathrm{W}$, $2,830 \mathrm{~m}$.

146. Reserva La Florida, 7 km O Ibatín, sobre Río Pueblo Viejo (Monteros) $-27^{\circ} 11^{\prime} 30^{\prime \prime} \mathrm{S},-65^{\circ} 40^{\prime} 6.6^{\prime \prime} \mathrm{W}, 549 \mathrm{~m}$. 
147. Reserva Provincial Aguas Chiquitas, sobre Río Aguas Chiquitas (Burruyacú) -260 36' 32.40" S, -650 10'36.6”W, 605 m.

148. Río Grande, $5 \mathrm{~km}$ al $\mathrm{S}$ de El Siambón (Tafí Viejo) -26 $46^{\prime} 6^{\prime \prime}$ $\mathrm{S},-65^{\circ} 28^{\prime} 6^{\prime \prime} \mathrm{W}, 937 \mathrm{~m}$.

149. Río Nío, $4 \mathrm{~km}$ al O, camino hacia Alto de Medina (Burruyacú) $-26^{\circ} 26^{\prime} 43.20^{\prime \prime} \mathrm{S},-65^{\circ} 01^{\prime} 36^{\prime \prime} \mathrm{W}, 1,072 \pm 26 \mathrm{~m}$.

150. San Miguel de Tucuman (Capital) $-26^{\circ} 51^{\prime} \mathrm{S},-65^{\circ} 25^{\prime} \mathrm{W}$, $1,012 \mathrm{~m}$.

151. Santa Cruz, $10 \mathrm{~km}$ al S de Tafí del Valle (Tafí del Valle) -260 56'18.51"S, -650 43'22.54"W, 1,989 m.

152. Taco Ralo (Graneros) $-27^{\circ} 50^{\prime} \mathrm{S},-65^{\circ} 12^{\prime} \mathrm{W}, 343 \mathrm{~m}$.

153. Tapia (Trancas) -260 36' 15.83"S, -650 15'36.10"W, 685 m.

154. Tapia, cruce de ruta 9 y Río Tapia (Trancas) -260 36'37.84" S, $-65^{\circ} 15^{\prime} 58.03^{\prime \prime} \mathrm{W}, 674 \mathrm{~m}$.

\section{APPENDIX II}

List of localities

Alphabetical list of localities that do not belong to northwestern Argentina. It is included by Country, Specific location, Department, Province, State or Party in parentheses, Geographic Coordinates and Elevation.

Argentina

Bonifacio (Guaminí, Buenos Aires) -36 48' 56" S, -630 13' 22. 5" W, $130 \mathrm{~m}$.

Chivilcoy (Chivilcoy, Buenos Aires) -34' 53' 50.2" S, -60 01' 7.64" W, $55 \mathrm{~m}$.

Estancia La Daniela (Buenos Aires) not located

Estancia San José, sobre Río Negro (Patagones, Buenos Aires) $40^{\circ} 57^{\prime} \mathrm{S},-62^{\circ} 48^{\prime} \mathrm{W}, 31 \mathrm{~m}$.

Fortín Uno (Avellaneda, Río Negro) -38 50’ S, -65²6’W, 169 m.

La Plata (La Plata, Buenos Aires) -34 55' 16.5"S, -570 57'15.6” W, $3 \mathrm{~m}$.

Las Casuarinas (25 de mayo, San Juan) -310 49' S, -68 19' W, $562 \mathrm{~m}$.

Las Rosas (Belgrano, Santa Fe) -32。 28' 30.43" S, -610 34'36"W, $107 \mathrm{~m}$.

Puerto Madryn (Biedma, Chubut) 42。 46' S, -65 03’W, $101 \mathrm{~m}$.

Puesto La Carpa (Lavalle, Mendoza) -32॰ 46'S, -68 15’W, 597 m.

Puesto Pugin, Algarrobito (Lavalle, Mendoza) -32。 53'S, -670 18' $\mathrm{W}, 471 \mathrm{~m}$.

San Rafael (San Rafael, Mendoza) -34 37' S, -68 24'W, 752 m.

Santa Rosa (Santa Rosa, Mendoza) -3315'S, -68 10'W, 613 m.

Bolivia

Buen Retiro (Sara, Santa Cruz) 170 17' 36.29"S, -630 42' 52.52"W, $290 \mathrm{~m}$.

Río Yapacani (Ichilo, Santa Cruz) 1600’ S, -64² 25’W, 174 m.
Brazil

Nova Teutônia (Seara, Santa Catarina) -270 03' S, -52 24' W, $865 \mathrm{~m}$.

Chile

Valparaíso (Valparaíso, Valparaíso) -330 02' 50.06" S, 710 36' $45.68^{\prime \prime} \mathrm{W}, 18 \mathrm{~m}$.

Hungary

Budapest (Capital, Hungría Central) 470 29'52.48” N, $199^{\circ} 02^{\prime}$ 24.85"E, 109 m.

France

Bure (Mosa, Lorena) 48 30' 20.36" N, 50 21'30.24" E, 342 m.

Marsella (Bocas del Ródano, Provenza-Alpes-Costa Azul) 43 17' 47.34" N, 50 22' 11.21"E, 34 m.

Nigeria

Olokemeji (Ekiti) 7o 36'52.90"N, 50 14'29.6"E, 420 m.

Panama

Bambito-Cerro Punta (Tierras Altas, Chiriquí) $8^{\circ} 52^{\prime} 22.67^{\prime \prime} \mathrm{N}, 82^{\circ}$ 35'0.58"W, 1943 m.

Paraguay

Sapucay (Paragaurí) -250 40' S, -56 55'W, 193 m.

Tacuaral (Central) -25०07'07"S, -560 13'59.8"W, 164 m.

Villarica (Guairá) -2546'33.82"S, -56² 26'58.53"W, 179 m.

Peru

4 km NO Pomata (Puno, Chucuito) -16 16'S, -690 16'W, 3819 m. Caylloma (Caylloma, Arequipa) -15 09' S, 71 45’W, 4493 m.

Uruguay

Paso Pache Antiguo puente, Río Santa Lucia (Canelones, Canelones) $-34^{\circ} 22^{\prime} 21.02^{\prime \prime} \mathrm{S},-56^{\circ} 16^{\prime} 29.96^{\prime \prime} \mathrm{W}, 18 \mathrm{~m}$. 